\title{
BARRIERS AND TRIGGERS TO ADOPTING A PARTICIPATORY MODEL FOR CONSERVATION IN THE CORDILLERA AZUL NATIONAL PARK, PERU.
}

by

Emilio Rodríguez-Izquierdo

Thesis

ENVIRONMENTAL STUDIES 593

[2009]

A 90 point thesis submitted to Victoria University of Wellington, as partial fulfilment for the degree of Master of Environmental Studies

School of Geography, Environment and Earth Sciences

Victoria University of Wellington

[April, 2009] 


\title{
BARRIERS AND TRIGGERS TO ADOPTING A PARTICIPATORY MODEL FOR CONSERVATION IN THE CORDILLERA AZUL NATIONAL PARK, PERU.
}

\author{
Emilio Rodríguez-Izquierdo
}

\begin{abstract}
Participatory approaches to the conservation management of protected areas are being implemented worldwide due to cost-effective and moral reasons. However, given the wide spectrum of participation, levels of participation across the conservation management process might vary from one stage to another. This study presents a unique analysis of how participation varies through the conservation management process, and provides the first step towards creating multi-variate models containing key determinants of perceived participation.

This thesis is based on research in the Cordillera Azul National Park, a relatively new protected area in the Peruvian Amazon, where I interviewed some of the main stakeholders and conducted a questionnaire in three communities of the Park's buffer zone. My main findings are: levels of participation did indeed vary across different stages of the Park's management. Also, the perceived benefits and costs of the National Park together with the attitudes towards conservation were influencing the perceived responsibility for the Park's management. Thus, I suggest that if managers want to increase community participation in the protected area's management, they might need to focus on identifying those community members with particular attitudes and concentrate on the benefits and costs of conservation.
\end{abstract}

Key words: community participation, conservation management, Cordillera Azul National Park, Peru, attitudes, perceived benefits and costs. 


\section{Acknowledgements}

First and foremost I would like to thank my supervisor Dr. Michael Gavin for the advice, (the always positive) comments, and encouragement he has given me throughout this project. I not only learned a lot from you, but I could not have finished this study without your support. Muchas gracias!

I would also like to thank all the participants in this research. Without your contributions, my research would not have been possible. I am especially grateful to all the inhabitants of Chambira, Selva Andina and Santa Rosillo for their hospitality and sincere generosity. Community members provided both valuable time and information. Dyusulpaa/ Muchas gracias!

Great thanks to Miguel Macedo, Miguel Vásquez and all the staff of CIMA, and Rubén Paitán of INRENA for their invaluable assistance and advice. I also learned enormously from you, and you impressed me with your cordiality and friendliness. Mis más sinceras gracias!

I am grateful to Education New Zealand for your generous offer -2007 New Zealand Postgraduate Study Abroad Award; and also to the School of Geography, Environment, and Earth Sciences for awarding me a 2008 Strategic Research Grant. You enabled me to travel and stay longer in the field.

Special thanks to Rosa, Amaya and Andrew Cross for their warmth, hospitality and encouragement throughout these three years, you made me feel at home. Also, I really want to thank Alonso Ocampo and Yannik Behr for their support, and for all the endless talks and laughs. Big thanks to the rest of my friends (Jenny, Josue, Jan and Karly, John, Claire P., David W., Claire R., Ivan and Terezka, etc.) for all the good times we had together. To all of you: Muchas Gracias/Vielen Dank!

Lastly, and most importantly, I want to thank all my family for their endless support. I am really grateful to my parents for all their love and financial support that made my dreams come true. Your continual affection ad advice has always encouraged me to do what I love. From the bottom of my heart, I also thank my sister for all her love. Gracias de todo corazón! 


\section{Table of Contents}

Abstract

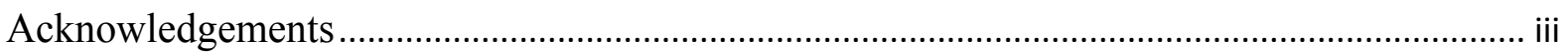

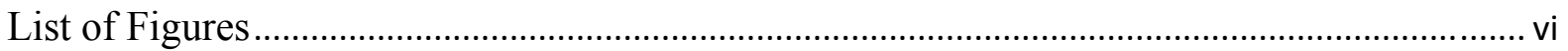

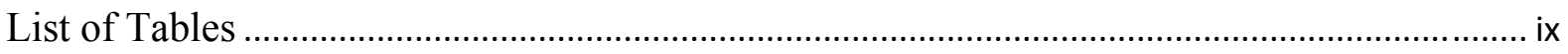

Chapter 1: Introduction .............................................................................................................. 1

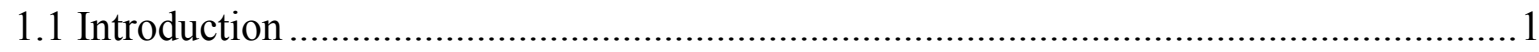

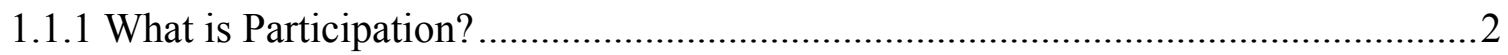

1.1.2 Participation across Conservation Management................................................. 4

1.1.3 The Link between Perceived Participation and the Perceived Benefits and Costs of

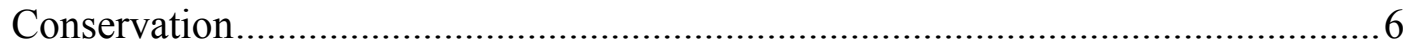

1.1.4 Barriers to more Participation in Conservation .................................................... 8

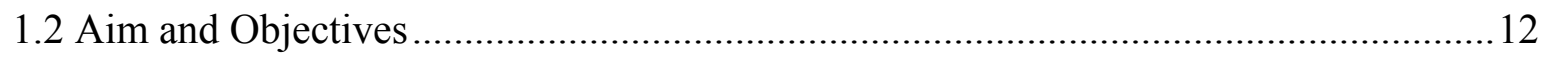

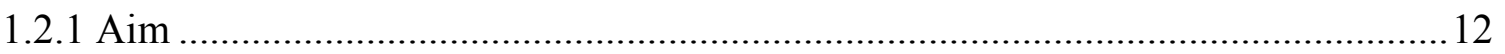

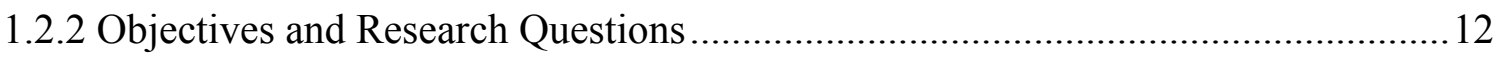

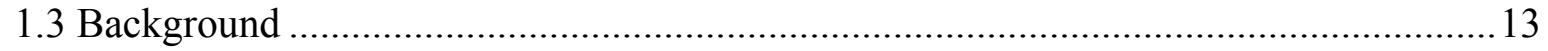

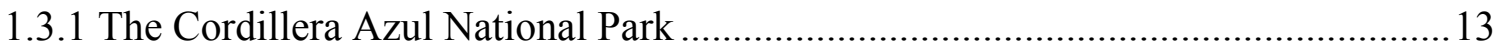

1.3.2 The Management of the Cordillera Azul National Park ......................................... 14

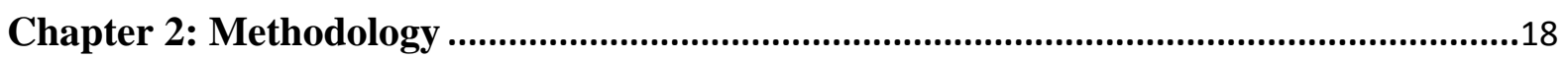

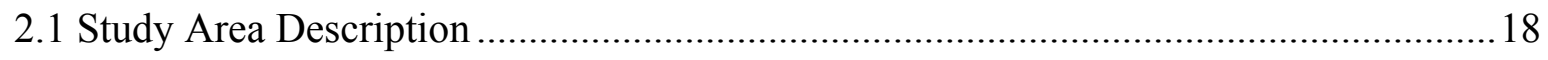

2.1.2 Communities’ inhabitants: Indigenous, Naturales and Immigrants ......................20

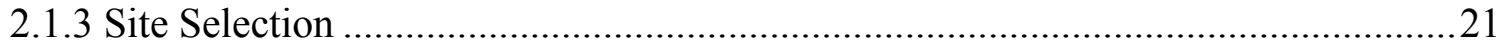

2.1.4 Brief Description of each Community ..............................................................22

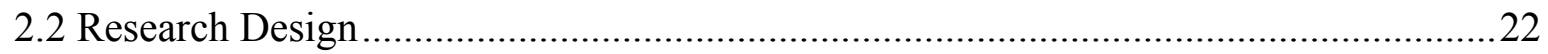

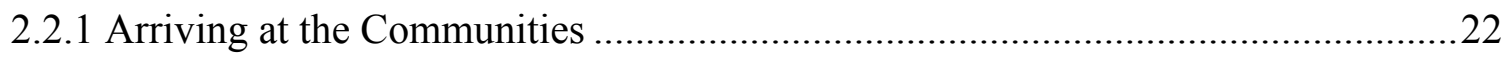

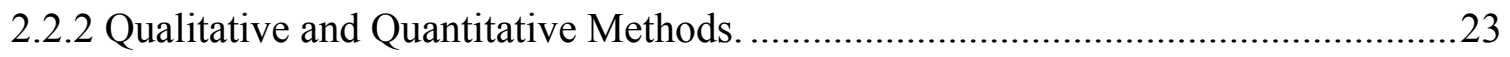

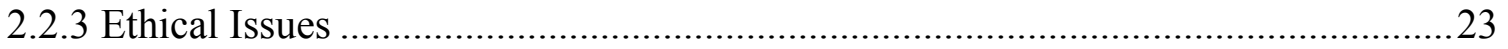

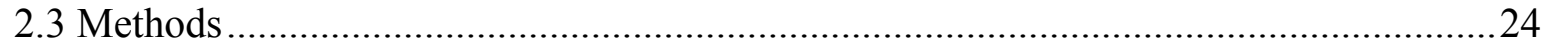

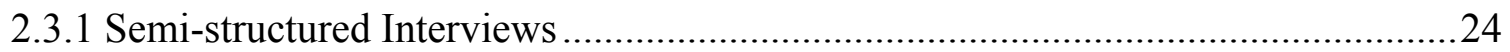

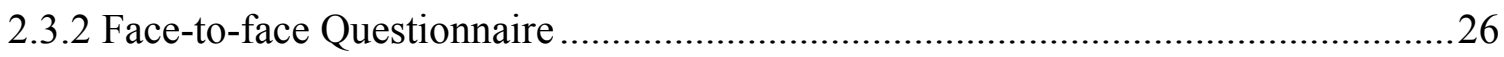

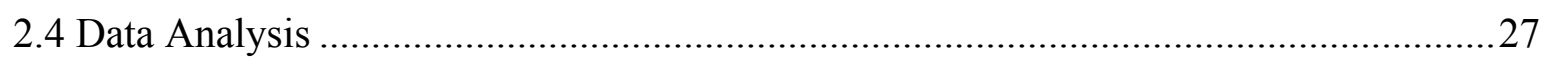




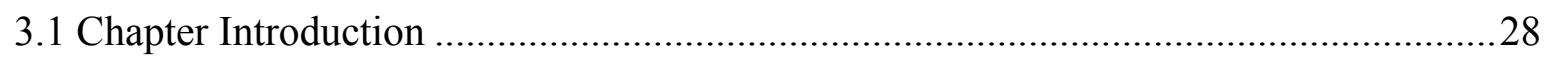

3.2 Levels of Participation at Different Management Stages............................................29

3.2.1 Perceived Levels of Participation in the Park's Establishment ...............................31

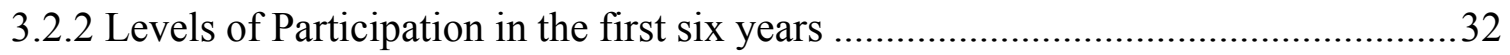

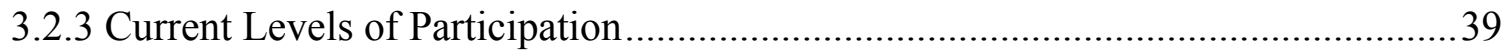

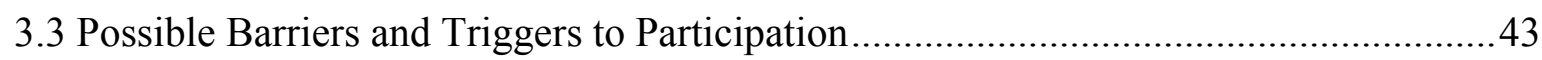

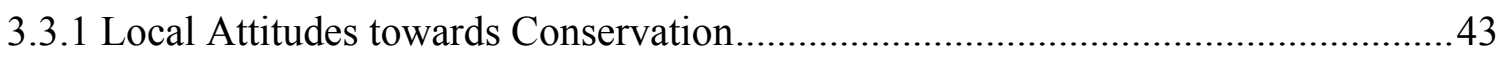

3.3.2 Communities-Conservationists Relationships ................................................ 45

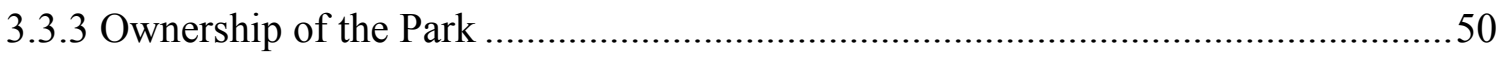

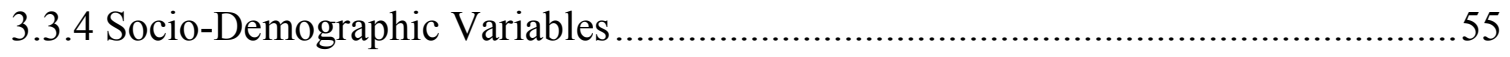

3.4 Relationship between Participation and Perceived Benefits and Costs ........................57

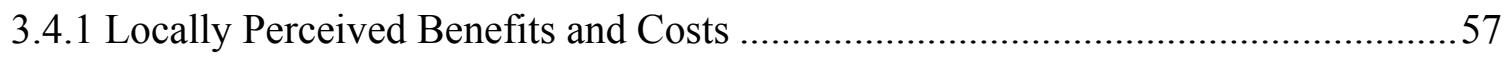

3.4.2 Conservationists' Perceptions of Communities' Park Acceptance and Perceived

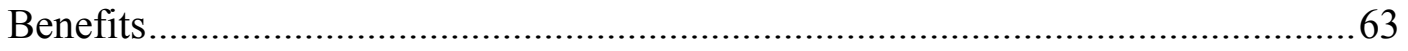

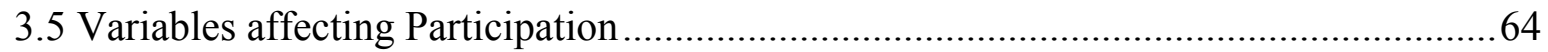

Chapter 4: Discussion and Conclusions ..............................................................................

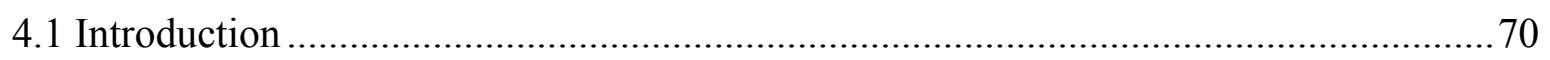

4.2 Estimating Levels of Participation across PNCAZ's Management Stages .................... 70

4.3 Participation link to Perceived Protected Area's Cost-Benefits....................................75

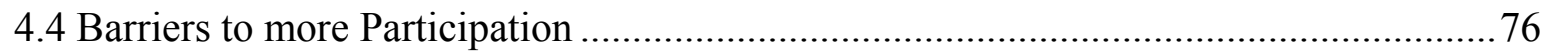

4.4.1 Views of Participation and Attitudes towards Community Participation.................77

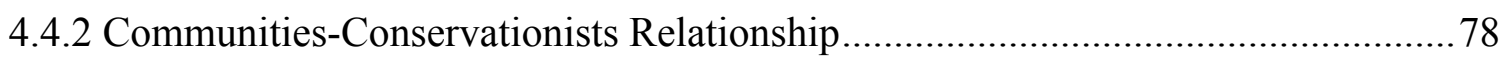

4.4.3 Communities' Perceived Control over the PNCAZ ..............................................79

4.4.4 Effect of Socio-Demographic variables on Participation ......................................79

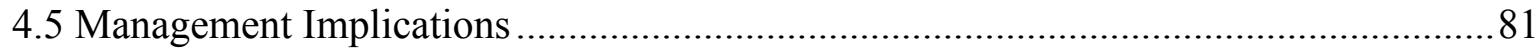

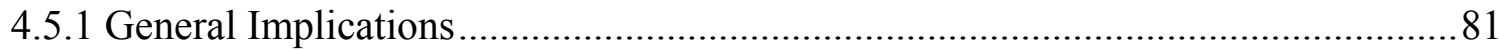

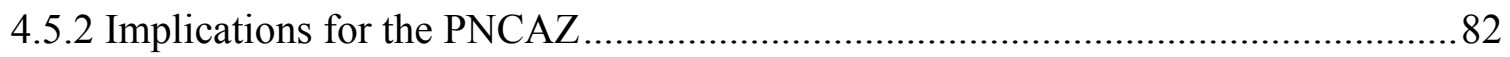

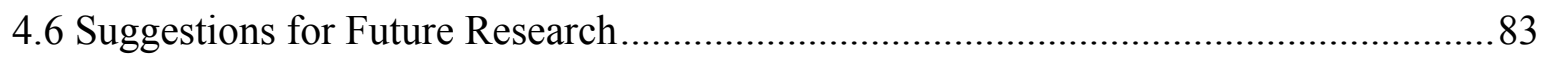

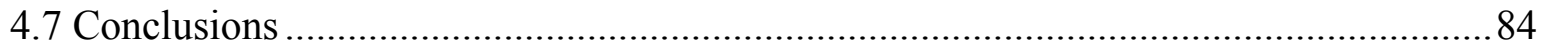

Appendix 1: CIMA's working sector division of the Park....................................................... 86

Appendix 2: Written permission of the Head of the Park............................................................ 87 
Appendix 3: Information Sheet and Informed Consent Form for Semi-structured Interview

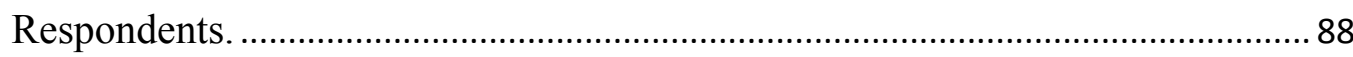

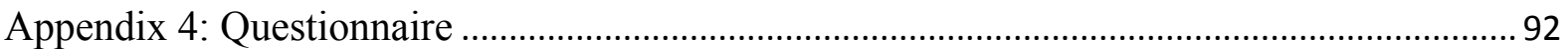

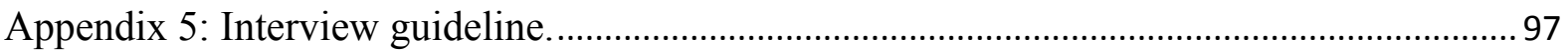

Appendix 6: Respondents views of the ownership of the Park................................................... 98

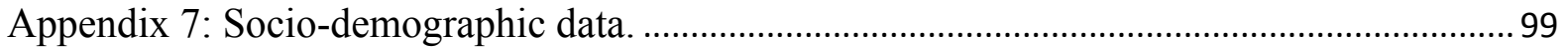

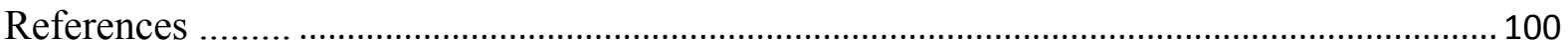




\section{List of Figures}

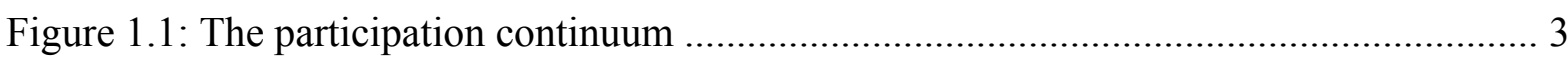

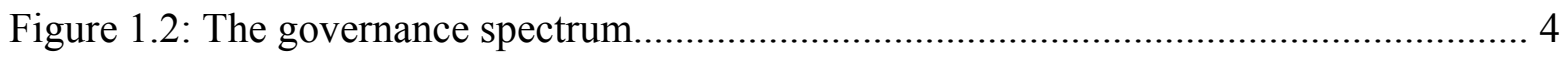

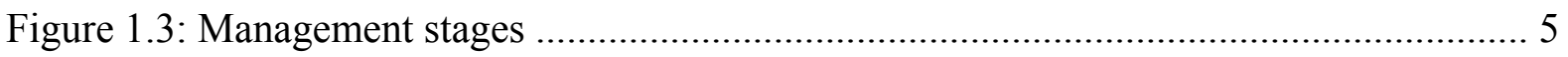

Figure 1.4: Potential variables affecting participation in conservation ................................. 9

Figure 2.1: The Location of the Cordillera Azul National Park, showing political departments and the other Peruvian Protected Areas ........................................ 19

Figure 2.2: The location of the three communities involved in the study........................... 20

Figure 3.1: The PNCAZ's management stages in the generic management

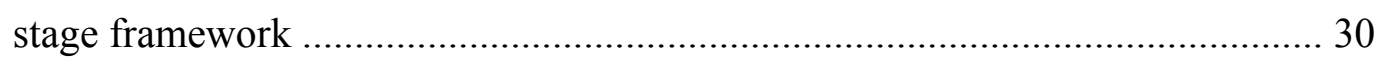

Figure 3.2: Perceptions about communities participating in the Park's decisions ................ 35

Figure 3.3: Community people awareness of Acuerdos Azules .......................................... 38

Figure 3.4: Perceived involvement of local people in the Park's management .................... 39

Figure 3.5: Communities perceived responsibility for the Park's management .................. 40

Figure 3.6: Desire for more participation in the management of the Park ........................... 44

Figure 3.7: Respondents' views of their relationship with the Park staff .......................... 47

Figure 3.8: Respondents' perceptions about CIMA staff listening to community people ..... 48

Figure 3.9: Respondents' perceptions about Park guards listening to community people .... 49

Figure 3.10: Respondent's perception of the PNCAZ's tenure ........................................ 51

Figure 3.11: Relationship between ownership and perceived local involvement

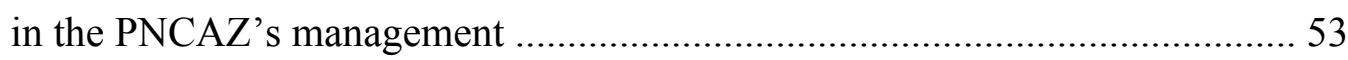


Figure 3.12: Relationship between ownership and perceived community responsibility for the Park's management .....

Figure 3.13: Views of the benefits emerging from the Park 57

Figure 3.14: Views of the benefits from the bush inside the Park 59

Figure 3.15: Opinions about costs caused by the Park 60

Figure 3.16: Opinions about the Park having more positive impacts 61

Figure 3.17: Potential variables affecting Perceived Participation in the PNCAZ 65

Figure 4.1: PNCAZ management stages in the participation continuum 72 


\section{List of Tables}

Table 2.1: List of interviewees 25

Table 3.1: Number of participants per community 28

Table 3.2: Relationship between locally perceived participation and locally perceived communities-conservationists relationship 50

Table 3.3: Spearman correlations coefficients for the socio-demographic variables 56

Table 3.4: Correlation between perceived participation and the locally perceived benefits and costs 62

Table 3.5: Spearman's correlation coefficients between the perceived participation variables and its potential predictors 66

Table 3.6: Outline of the results from the logistic regression analysis for 'Perceived responsibility for the Park's management' 68

Table 4.1: Levels of participation at different management stages 71 


\section{Chapter One: Introduction}

\subsection{Introduction}

Numerous studies demonstrate that participation of local communities is a crucial component of conservation management (e.g., Adams \& Hulme 2001; Carpenter 1998; Horwich \& Lyon 2007; Kothari 2006; Ostrom 1990; Spiteri \& Nepal 2006; Tai 2007; Thakadu 2005). A more participatory approach to the management of protected areas seems to have the greatest potential for generating a legitimate process of conservation; one that is regarded as right and just by the people most affected (Brechin et al. 2002; da Silva 2004; Haller et al. 2008; Wilshusen et al. 2002). Also, participatory processes in conservation management seem to increase compliance and reduce conflicts arising from the restraints in resource use that are intrinsic to any biodiversity protection programme (Agrawal \& Gibson 2001; Berkes 2007; Brechin et al. 2002). Thus, the literature suggests that local participation in natural resource management is preferred to more protectionist approaches for two main reasons: For one, more participatory management can be more cost-effective. Community participation can foster communities' vested interests in conservation, and consequently reduce enforcement costs as well as improve the effectiveness of conservation management (Menzies 2007; Spiteri \& Nepal 2006; Thakadu 2005). In addition, there are social justice or moral reasons, as participatory processes are supposed to take into account the views and opinions of those more directly affected by protected areas (Adams \& Hulme 2001; Brechin et al. 2002; Horwich \& Lyon 2007; Menzies 2007; Spiteri \& Nepal 2006). This thesis will contribute to the existing conservation management literature in four ways: by examining how participation varies through the conservation management process; by analysing potential barriers to achieve greater levels of participation; by examining the link between perceived participation and locally perceived benefits of conservation planning; and finally, by providing locally relevant information on the impacts of participation on the Cordillera Azul National Park, a relatively new Peruvian protected area in the biodiversity hotspot of the Peruvian Amazon.

In the remainder of this chapter, I will first outline definitions of participation and how it varies across conservation management; followed by a review of the relationship between participation and the perceived benefits and costs of conservation, the barriers to participation in natural resource management, and an overview of the Cordillera Azul National Park. 


\subsubsection{What is Participation?}

The protectionist approach to conservation was the main management paradigm until a move towards more participatory management models started approximately two decades ago (Berkes 2007; Chapin 2004; Gavin et al. 2007; Meffe et al. 2002; Robinson \& Redford 2004). Promoters of strict protected areas argue that population growth further increases pressure on natural resources, and therefore it is critical for the conservation of natural resources to set aside these areas (Agrawal \& Gibson 2001; Berkes 2007). Furthermore, the protectionist approach posits that local communities which rely on these natural resources, can be expected to exploit these resources without restraint (Agrawal \& Gibson 2001). Lastly, under this argument, resource degradation takes place because private property rights are absent. Thus, the protectionist management paradigm interpretation of Garret Hardin's (1968) 'Tragedy of the Commons' is that conservation policies should aim at an authoritarian protection of natural resources which will solve the absence of property rights that leads to unsustainable uses of natural resources (Agrawal \& Gibson 2001; Berkes 2007; Bromley 1991).

In the late 1980s and early 1990s however, there was a major paradigm shift towards a more "people-oriented" conservation. These types of participatory management models include "community-based natural resource management" (CBRM), "collaborative resource management" (CRM), "grassroots conservation," "internally-motivated conservation programs," "integrated conservation and development projects" (ICDPs) and "communitybased conservation" (CBC) (Berkes 2007; Brechin et al. 2002; Chapin 2004). There are differences among these terms in relation to what the projects' goals are and the scale of the projects (Horwich \& Lyon 2007). Nonetheless, these participatory models emerged as a response to the inefficiencies of state-managed conservation, and they all seek to involve local communities in conservation to varying degrees (Menzies 2007).

Definitions of participation vary depending on the context and background in which participation is applied (Kumar 2002). Community participation in conservation management involves a wide spectrum reflecting the continuum in conservation from protectionist approaches to community-driven programmes (see Figure 1.1). In this spectrum participation ranges from people being told what to do, to local people in complete control over their own resources and lives (Kumar 2002). Thus, in terms of community participation, an instructive process would mean virtually no participation, as communities are only informed of management decisions. On the other side of the participation continuum are informative 
practices where communities are the ones informing the government about management decisions (da Silva 2004).

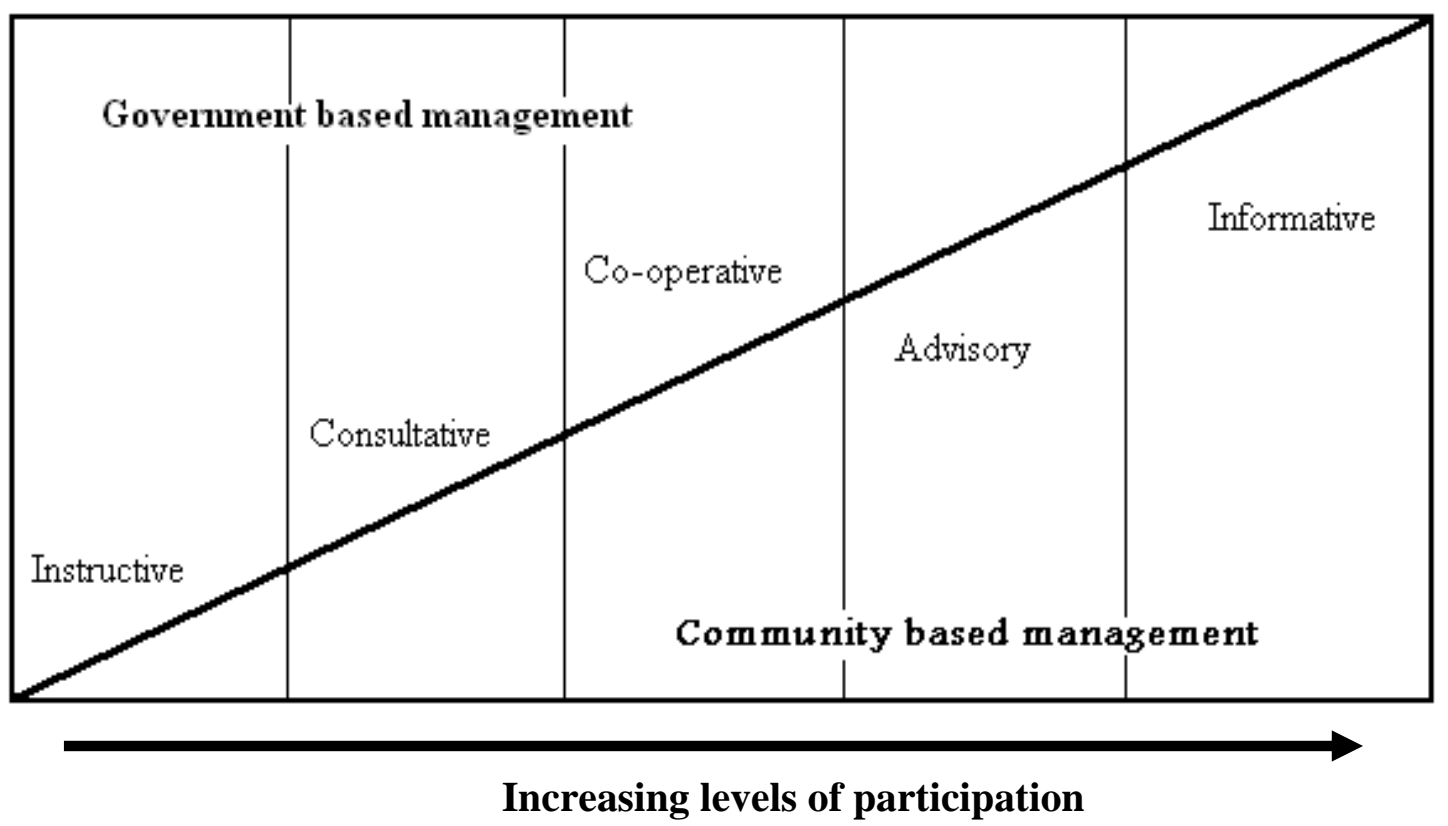

Figure 1.1: The participation continuum (Adapted from da Silva 2004).

Community participation can be viewed as a process of community empowerment (Adams \& Hulme 2001; Slocum et al. 1995). Through increased participation, individuals and local groups are given more power to organize and shape their own lives (Slocum et al. 1995). Participation is also a matter of governance, and hence a matter of power balances (da Silva 2004). If some people are gaining power that implies that others are losing it (Mayo \& Craig 2004). As participation has different meanings for different people, the participation continuum translates into a governance spectrum where the varying degrees of participation in natural resource management can be seen as different options in the governance of protected areas (see Figure 1.2). Consequently, some organizations, such as the World Bank, have seen community participation as a means to achieve specific goals or objectives; so it could be said that even though they foster a participatory approach, this form of conservation management is still largely top-down (Mayo \& Craig 2004). Alternatively, other organizations (mainly NGO's) see participation as an end in itself, where the focus is on building the peoples' ability to take part in the management process (Kumar 2002; Mayo \& Craig 2004). 


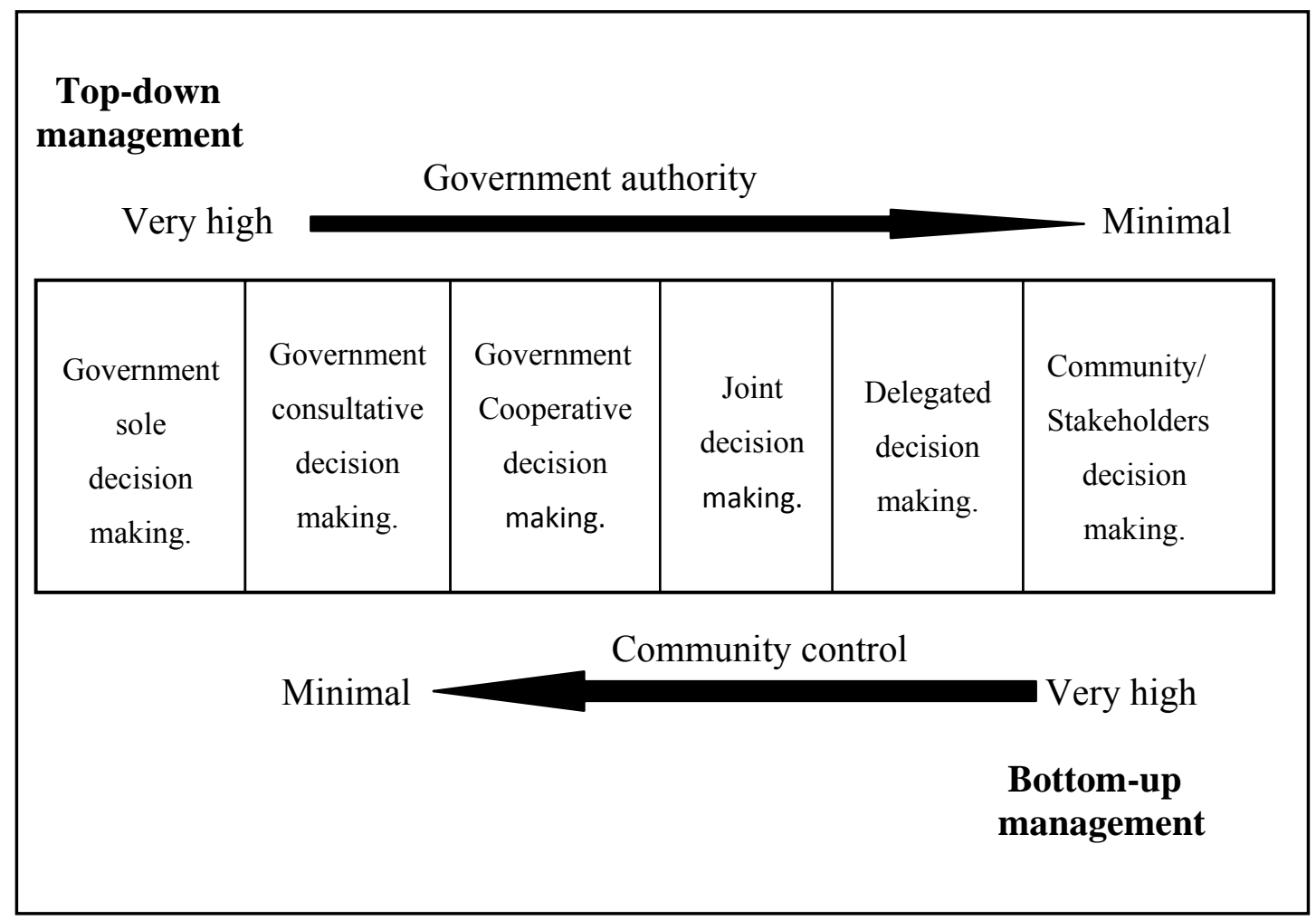

Figure 1.2: The governance spectrum (Based on Dearden et al. 2005 and

Horwich \& Lyon 2007).

The literature in conservation management mainly refers to levels of participation in a generic sense; however conservation is not one event but a process with many stages (Berkes 2007; Margules \& Pressey 2000; Salafsky \& Margoluis 2004). Therefore, given the wide spectrum of participation, levels of participation across the conservation management process will be likely to vary from one stage to another.

\subsubsection{Participation across Conservation Management}

Conservation encompasses a mix of disciplines (including fields such as biology, economics, geology, philosophy, etc.) with the ultimate goal of preventing the loss of life on this planet (Hambler 2004). Also, conservation happens in a complex system, with multiple and unpredictable factors affecting conservation action (Salafsky \& Margoluis 2004). Thus, conservation management is an evolving, iterative process including different stages (see Figure 1.3), such as planning, implementation and monitoring (Berkes 2007; Margules \& Pressey 2000; Salafsky \& Margoluis 2004).

The planning stage involves determining who will participate in the project and the overall mission (Salafsky \& Margoluis 2004). This stage includes collecting and reviewing all the 
data and information about the protected area and its surroundings to define the (conservation) management goals and determine how they may best be achieved (Margules \& Pressey 2000; Worboys et al. 2005). These actions might end up with the development of a management plan outlining the main goal and objectives of the project and the specific actions that will be undertaken to achieve the project aim (Salafsky \& Margoluis 2004). After that, the implementation phase involves all the actions required to achieve the management targets (Salafsky \& Margoluis 2004; Worboys et al. 2005). Finally, the monitoring stage involves assessing the project performance; this phase also includes the evaluation of all the management tools implemented (Margules \& Pressey 2000; Worboys et al. 2005). In what is known as adaptive management, the monitoring stage is integrated into the project as an essential step to improve the management decisions being made (Salafsky \& Margoluis 2004). Thus, results from the monitoring phase should be used as feedback information to modify project objectives and adapt management tools and actions to fit changing conditions and the availability of new information (Margules \& Pressey 2000; Salafsky \& Margoluis 2004).

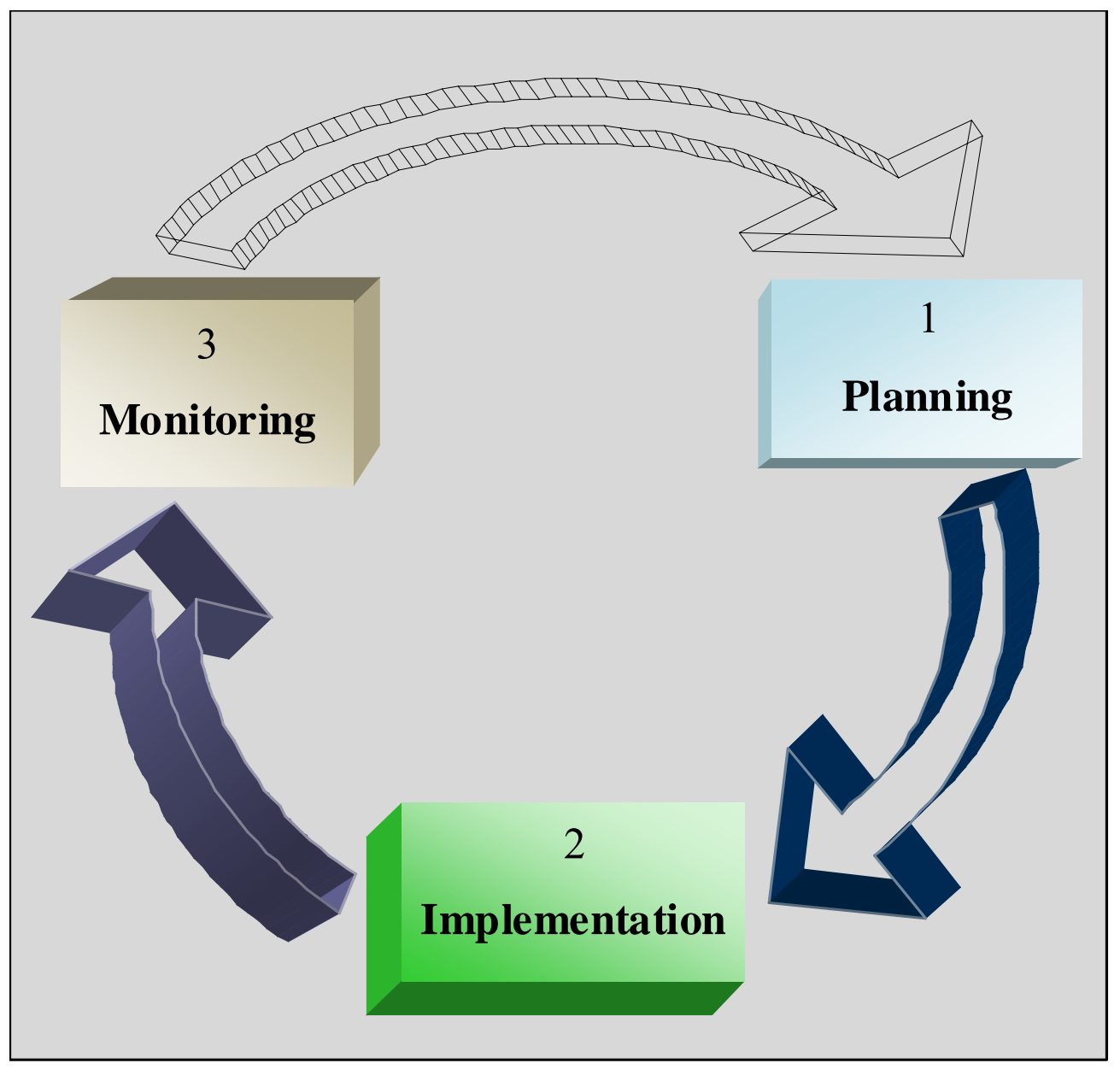

Figure 1.3: Management stages. 
Literature on conservation management has tended to focus on the outcomes of participatory processes at either the end of a conservation project or over certain periods of time, but without distinguishing the management stages comprised in that period (Berkes 2007). However, the conservation process comprises different stages (Berkes 2007; Margules \& Pressey 2000; Salafsky \& Margoluis 2004), each with an opportunity for different levels of participation.

Therefore, this thesis will make a new and important addition to the existing literature in conservation management by analysing how participation varies through the conservation management process.

\subsubsection{The Link between Perceived Participation and the Perceived Benefits and Costs of Conservation}

The literature suggests a potentially strong link between the locally perceived net benefits of conservation and local levels of participation. The relationship between these variables may go in either direction. On one hand, incentives are critical in getting local communities to participate in conservation management (Castro \& Nielsen 2001; Haller et al. 2008; Hedge \& Enters 2000; Kiss 2004; Menzies 2007; Spiteri \& Nepal 2006; Thakadu 2005). In other words, the perceived benefits and costs of conservation might change community people's interest in participating, and thus affect the levels of local participation in conservation. On the other hand, community participation in conservation seems to foster communities' vested interest in conservation (Menzies 2007; Spiteri \& Nepal 2006; Thakadu 2005). That is to say, locally perceived participation will influence the locally perceived benefits and costs.

Given that the conservation of natural resources usually implies high costs related to State enforcement, the protection of these resources is usually imperfect and inefficient (Menzies 2007; Ostrom 1990; Spiteri \& Nepal 2006; Thakadu 2005).Thus, the conservation of natural resources often relies on communities' agreement to abide by management regulations. Consequently, to effectively manage a protected area, the loss of rights by local people and the opportunity costs - the best alternatives given up when choices are made (Daily \& Farley 2004)- of conservation, must be outweighed by economic benefits and/or other incentives that encourage communities' self-enforcement (Adams \& Hulme 2001; Salafsky et al. 2001; Spiteri \& Nepal 2006; Thakadu 2005). Although it is not clear that more participation will necessarily bring more benefits to communities, it seems that if community members are 
expected to participate in the management of protected areas, then local people need to perceive that the benefits of participating in the management process will be greater than the costs. Thus, incentives become a crucial component of participatory processes (Castro $\&$ Nielsen 2001; Haller et al. 2008; Hedge \& Enters 2000; Kiss 2004; Menzies 2007; Spiteri \& Nepal 2006; Thakadu 2005).

Therefore, it seems that increased participation might increase locally perceived benefits of conservation (Menzies 2007; Spiteri \& Nepal 2006; Thakadu 2005). Nonetheless, if people perceive more benefits than costs then they may also be more willing to participate. Thus, the relationship between perceived participation and locally perceived benefits (i.e. more perceived benefits than costs) appears to be a two-way relationship.

In fact, Haller et al. (2008) are the only authors who have empirically examined the relationship between participation in the management of protected areas and locally perceived benefits. Haller et al. (2008) show that based on one case study from the Amarakaeri Communal Reserve, in the Peruvian Department of Madre de Dios, the participatory conservation process allowed indigenous leaders to gain more political power permitting them to secure their land rights. These land rights were a critical benefit to local people and consequently they supported the protected area. Conversely, in a different Tanzanian case study, Haller et al. (2008) found that communities opposed a participatory conservation process due to its high economic costs and lack of political gains. Therefore, increased local participation in conservation does not necessarily mean that both communities and protected areas are better off (Wells et al. 2004). It appears however, that the benefits from participatory conservation approaches are principally: the generation of a legitimate process; a more cost-effective conservation model; communities' empowerment; and the ecosystem services and ecological benefits of a protected area. On the other hand, conservation costs include local loss of rights and land, which might involve involuntary resettlement of local people or communities (Agrawal et al. 2008); opportunity costs of conserving the resources; and occasionally more community responsibilities, which require time and resources that communities might not be able to sustain by themselves (Thakadu 2005). Nevertheless, it seems that communities will be willing to participate in conservation as long as they perceive it will benefit them (i.e. the benefits outweigh the costs) in some way (Adams \& Hulme 2001; Haller et al. 2008; Kumar 2002; Menzies 2007; Thakadu 2005). 
Therefore, if one of the outcomes from increased participation is an increase in the locally perceived benefits, then it would reinforce the importance of fostering participatory approaches to conservation. Alternatively, if an increase in the locally perceived benefits or costs affects levels of participation, it would be an important variable to take into account when establishing participatory conservation process.

Therefore, in this case study the relationship between perceived participation and the locally perceived benefits and costs will be empirically examined. Further exploring this relationship will be an important contribution to the existing yet sparse literature in conservation management that has investigated the correlation between perceived participation and the benefits and costs of conservation.

\subsubsection{Barriers to more Participation in Conservation}

There are many factors affecting levels of community participation in conservation programs. My research focuses specifically on five potential barriers (see Figure 1.4) to greater participation: local perceptions of the benefits and costs of the project; levels of devolution of power to local people; levels of local acceptance and perceived control over the project; community attitudes towards conservation; and lastly, the relationship between community members and conservation agencies. Also, communities are not homogeneous entities where all individuals share the same interest and values (Agrawal \& Gibson 2001). Conservation values of individuals may be affected by different socioeconomic variables, such as residence time or education levels (Gavin \& Anderson 2007; Spiteri \& Nepal 2006; Thakadu 2005), which in turn might affect the willingness of people to participate and their perceptions of the benefits generated by conservation programs (Thakadu 2005). Figure 1.4 presents an overview of the factors studied in this thesis. 
Socio-demographic variables:

- Residence Time.

- Education Levels.
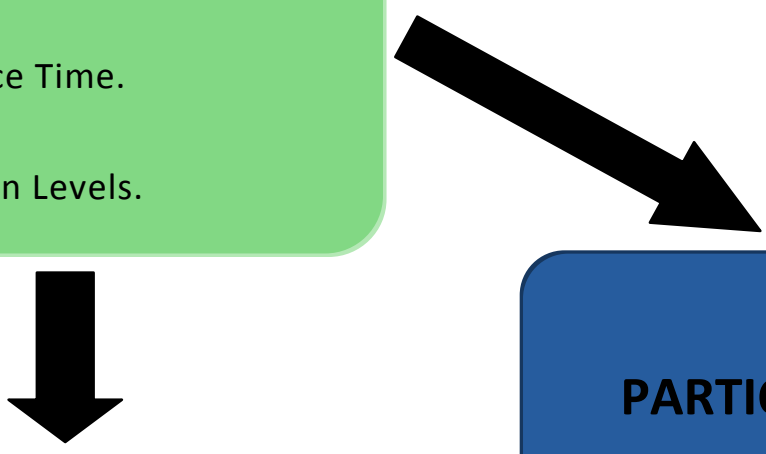

Potential Barriers and Triggers:

- Devolution of Power.

- Attitudes towards Conservation.

- Communities-Conservationists

Relationship.

PARTICIPATION

- Perceived Ownership of the project.

- Perceived Benefits and Costs.

Figure 1.4: Potential variables affecting participation in conservation.

Figure 1.4 illustrates that the potential barriers to participation in conservation management are also likely to be affected by the levels of participation as well. Also, literature shows that socio-demographic variables might affect participation and the potential barriers too (see Figure 1.4). I will now explore the literature related to each of these focal barriers to participation.

In many cases community-based conservation performance has been below expectations (Adams \& Hulme 2001; Agrawal \& Gibson 2001; Berkes 2003; Kellert et al. 2000; McShane \& Wells 2004; Mutandwa \& Gadzirayi 2007). One explanation focuses on the inadequate devolution of power and responsibility to communities. Thus, communities may be asked to bear the burden of protection and caring of protected areas ${ }^{1}$, but may not enjoy the same level of decision-making authority (Kumar 2002; Menzies 2007). Hence, under the rhetoric of participation, many conservation projects appear to be highly participatory, reaching levels of

\footnotetext{
${ }^{1}$ This is not to say that communities are responsible for protecting protected areas, but rather that these tasks are the only space left for communities' participation in conservation.
} 
co-operation - usually termed as co-management- or even advisory levels (see Figure 1.1), but it often turns out that when community participation is analysed in terms of community power, these same conservation programmes are falling more on the side of minimal community control of the project (see Figure 1.2) (Kumar 2002). For instance, a study about governance of protected areas by Dearden et al. (2005) pointed out that based on responses from 41 countries, the overall management of protected areas had improved (between 1992 and 2002). However, although most of the respondents felt that the stakeholders' participation in the management had increased, many believed that community involvement could still be improved by increasing the levels of power sharing.

Despite many conservation projects are considered as participatory ventures, the majority of these projects are initiated and managed outside the communities (Menzies 2007). It is not surprising then, that many of these projects fail to achieve high levels of community participation. First, communities are usually more interested in social and economic development than in biodiversity protection (Kellert et al. 2000). Thus, communities' interests usually diverge from the goals of conservation-focused projects (Agrawal \& Gibson 2001; Berkes 2007; Menzies 2007; Wells et al. 2004). In turn, without a clear incentive, communities might be reluctant to be involved in conservation projects (Castro \& Nielsen 2001; Spiteri \& Nepal 2006). Second, communities may not perceive that they have any control over the project if there is only token power sharing between conservationists and local people (Adams \& Hulme 2001). Moreover, many conservation projects have been planned and started outside the communities (Berkes 2007; Chapin 2004; Menzies 2007; Sayer \& Wells 2004). Consequently, once the project was started, conservation and/or government agencies had to invest a lot of time and money to ensure communities' perceived ownership and acceptance of the project (Sayer \& Wells 2004). Thus, community participation is often seen as the means to secure community support in the long-term (Chapin 2004; Kumar 2002; Mayo \& Craig 2004). Therefore, devolution of power will influence local people's perceptions of their responsibility over the protected area's management, which in turn is an important precursor to community participation in conservation (Adams \& Hulme 2001; Kumar 2002; Menzies 2007). Furthermore, symbolic power sharing is also likely to undermine the relationship between communities and conservationists, and thereby affect the attitudes of community members towards conservation (Spiteri \& Nepal 2006). 
Local people's attitudes towards protected areas can be as much a trigger to participation as they can be a barrier to community involvement in conservation management. Behaviour (i.e., manner of acting) can be affected by numerous variables (e.g. social and cultural norms, peoples' values, environmental awareness); and attitudes, defined as positive or negative feelings about someone or something; are one key component of people's behaviour (Jacobson et al. 2006; Kollmuss \& Agyeman 2002). In addition, if there is no mutual trust between conservationists and local people, or communities distrust conservationists' intentions, then local people will not be willing to participate (Adams \& Hulme 2001; Menzies 2007; Thakadu 2005).

Also, socio-demographic variables such as time of residence and levels of education might influence local people's use of natural resources (e.g., Gavin \& Anderson 2007), and hence, their attitudes towards conservation as well as the perceived costs and benefits of conservation (Adams \& Hulme 2001; Spiteri \& Nepal 2006; Thakadu 2005). Thus, sociodemographic variables would indirectly affect participation in conservation. For example, Gavin \& Anderson (2007) found that residence time was a key factor shaping resource use patterns in the Cordillera Azul. Given the role of the Cordillera Azul National Park in placing limits on resource use, then residence time might influence a household's motivation to participate in management. Families that have been in the region for a longer time are more likely to extract more resources from the forest (Gavin \& Anderson 2007), and in turn may have more interest in the outcomes of park management. Also, levels of education have been found to influence attitudes toward conservation programs (Spiteri \& Nepal 2006). For example, households with lower literacy levels might have less labour access outside their communities and consequently be more dependent on local resources. Hence, attitudes towards conservation might also differ based on education levels (Hedge \& Enters 2000; Thakadu 2005), with the less literate households being more likely to support conservation (Thakadu 2005).

Therefore, the examination of all these possible barriers to increased participation in conservation management will represent the first attempt to create a multi-variate model of factors determining perceived participation. 


\subsection{Aim and Objectives}

\subsubsection{Aim}

To use the case study of the Cordillera Azul National Park in Peru to examine how participation may vary across stages of conservation management, what the potential triggers and/or barriers to increased community participation might be; and the possible management implications of perceived levels of participation.

\subsubsection{Objectives and Research Questions}

Objective 1: Examine the levels of local participation at different stages of the Park's management.

Objective 2: Examine the possible barriers to more participation in the Cordillera Azul National Park.

1) How different stakeholders understand participation in conservation.

2) What are local attitudes towards conservation?

3) What is the relationship between conservationists and local communities?

4) How the locally perceived ownership of the Park relates to perceived participation?

5) How different socio-demographic variables (time of residence and education levels) relate to perceived levels of participation?

Objective 3: Examine the relationship between locally perceived levels of participation and locally perceived costs and benefits stemming from the Park.

Objective 4: Explore the implications of the perceived levels of participation for the conservation management in the Cordillera Azul National Park. 
In the remainder of this chapter I will provide the necessary background of the case study area, the Cordillera Azul National Park, as well as outline the Park's administrative format and the main management tools applied. In Chapter 2: Methods, I will present the two methods -a questionnaire and semi-structured interviews- used in this thesis. Chapter 3: Results, focuses on the analysis of the findings of these two methods. Lastly, Chapter 5: Discussion and Conclusions, presents the findings in light of the objectives, and an interpretation of the results according to the literature reviewed at the beginning of this chapter.

\subsection{Background}

\subsubsection{The Cordillera Azul National Park}

Located in Northern Peru, the Cordillera Azul National Park comprises 1,353,190 hectares. The Park is a mix of mountain peaks and ridges, as well as broad lowland valleys and slopes, high-altitude lakes and marshlands. The Park represents one of the most geologically diverse areas in Peru with unusual, eroded rock formations and triangular-shaped hills known as 'Vivian' rock formations. The Cordillera Azul National Park's Andean forests are extraordinarily rich in biodiversity, being home to an estimated 4000 to 6000 plant species and an equally extraordinary diversity of animals. Some of these species are endemic, and also a small number of these species had been recently discovered (INRENA 2006). For instance, in 2000 a team comprised of Peruvian and international scientists carried out a Rapid Biological Inventory (a three-week survey) that registered more than 1,800 species of plants and animals, 28 of which were new to science (The Field Museum of Chicago 2007). Only a few groups of Cacataibo people live in voluntary isolation (not contacted) within the Cordillera Azul National Park (in the Southeast part of the Park). However, coca fields, logging operations, new roads, and rapidly growing communities lie just outside the Park's border (The Field Museum of Chicago 2007). The Park's buffer zone consist of over two million hectares, which is more densely populated on its western side (Gavin et al. 2007; INRENA 2006).

Once the results of the Rapid Biological Inventory were presented in March of 2001, the Agriculture Ministry decided to establish the Cordillera Azul National Park as soon as possible. Thus, the Peruvian Association for Conservation (Asociación Peruana para la Conservación -APECO) and the Field Museum of Chicago prepared all the technical files 
required for the creation of the protected area. In May 22, 2001, the President of Peru, Valentín Paniagua Corazao, signed a decree (Supreme Decree No 031-AG- 2001) establishing the Cordillera Azul National Park, the ninth Peruvian National Park (INRENA 2006; Young $\&$ Rodríguez 2006). Peru has approximately $13 \%$ of its territory within a national system of protected areas known as the National System of Natural Protected Areas (Sistema Nacional de Áreas Naturales Protegidas por el Estado-SINANPE), which consists of 55 protected areas, 11 of which are National Parks, the strictest form of biodiversity protection (Young \& Rodríguez 2006). Due to the fact that Peru's government dedicates a large percentage of its income to the payment of international debt, resources are usually insufficient to effectively manage all the protected areas (Gavin et al. 2007; Young \& Rodríguez 2006). For this reason most of the costs of the Peruvian protected areas are covered by international funds (Haller et al. 2008). Under new Peruvian regulations, protected areas can be officially managed by private organizations (Young \& Rodríguez 2006). Article 17 of the 1997 Peruvian Law of Natural Protected Areas (Law No 26834), claims that "the State recognizes and promotes private participation in the management of Natural Protected Areas" and provides six different modalities of private participation. An example of this private participation in the management of protected areas is the Cordillera Azul National Park.

\subsubsection{The Management of the Cordillera Azul National Park}

In this section, I will discuss six tools used for the management of the Cordillera Azul National Park. I will first discuss the Park's administrative format and the Cordillera Azul Management Plan; followed by a review of the Mapping of Social Assets and Resource Use and the Peasant Rounds. Finally, I will go over the Acuerdos Azules and the Management Committee.

A Peruvian NGO, Centre of Conservation, Research and Management of Natural Areas (Centro de Conservación, Investigación y Manejo de Áreas Naturales - CIMA) manages the Cordillera Azul National Park (Parque Nacional Cordillera Azul-PNCAZ ${ }^{2}$ ) in partnership with a government agency known as the National Institute of Natural Resources (Instituto Nacional de Recursos Naturales -INRENA), and with technical support from The Field Museum of Chicago. Contrary to previous strategies in Peru, where parks were managed

\footnotetext{
${ }^{2}$ From this point on, PNCAZ -or the Park- in this thesis will refer to both the Cordillera Azul National Park and its main buffer zone. Although neither CIMA nor INRENA can administer the buffer zone, the integrated management of the Park means that the buffer zone is considered as part of the PNCAZ.
} 
under protectionist policies, CIMA fosters a more participatory conservation strategy (Gavin et al. 2007). On August 1, 2008, CIMA was granted the Total Management Contract of the PNCAZ. According to the Peruvian Law of Natural Protected Areas (Law No 26834), under this type of management the NGO is in charge of the management and administration of the National Park for a maximum period of twenty years (Cerdán 2002). Also, the Ministry for the Environment was created on May 13, 2008, which meant that INRENA's functions are decreased to only be in charge of the surveillance and control inside the National Park, but not -as it previously was- in the Park's buffer zone (CIMA and INRENA staff, personal communication).

According to the Peruvian Law of Natural Protected Areas (Law No 26834, article 20) every protected area must have a Management Plan (Plan Maestro). Management Plans are the highest level planning documents of Peruvian's protected areas. These plans should be developed under participatory processes and need to be approved by a National Authority INRENA's Chief, and must be revised every five years. The first Management Plan for the PNCAZ was approved on November 26, 2004, and was valid until 2008. Given that CIMA was granted the Total Management Contract of the Park, it is now CIMA's responsibility to develop - under a participatory process- the new Management Plan within a year (Article 28 of the Resolution No 270-2001-INRENA).

As outlined in Figure 1.3 the first management stage is the planning phase which concludes with the creation of a management plan. Thus, the first PNCAZ's Management Plan was developed by INRENA in collaboration with CIMA. In doing so, an important management tool used by CIMA for both the data gathering and the participatory development of the PNCAZ's Management Plan was the Mapping of Social Assets and Resource Use (Mapeo de Usos y Fortalezas -MUF). The MUF combined participatory social asset mapping with resource use mapping in order to obtain socioeconomic and geographic information about the communities surrounding the National Park (Gavin et al. 2007). When, in 2003, the MUF was applied for the first time in Peru, a participatory approach was used with the information from 53 communities retrieved by community representatives called 'community facilitators' (facilitadores comunales) trained by CIMA (INRENA 2006). It was not a conventional participatory or rapid appraisal method mainly because the information was gathered over a period of two months, and it did not rely on the usual 'strengths, weaknesses, opportunities, and threats' (SWOT) framework that provides limited understanding of communities' capacities and attitudes (Gavin et al. 2007). The MUF has been applied again in 2005 and 
2008 to build on the baseline data. In both editions (2005 and 2008) the data gathering has been done directly by CIMA staff in meetings with some community representatives (numbers of communities' participants vary from two people to more than eight). Also, the number of communities involved has been increased to more than 80 communities in the 2008 MUF (CIMA staff, personal communication).

The data gathered via the MUF include a list of community organizations along with their role and importance. These data allow Park managers to target specific organizations for possible management collaborations. One of the main organizations present in many communities is the Peasant Rounds (Rondas Campesinas). The Peasant Rounds is a name given to autonomous peasant patrols in rural Peru. The Peasant Rounds started in the Peruvian department of Cajamarca in the mid-1970s as a protection force against theft, especially cattle rustling (Fumerton 2001). On the other hand, some communities organised Peasant Self-Defence Organisations (Comités de Autodefensa) in response to the coercion and violence exerted by the Shining Path $^{3}$ (Sendero Luminoso). In other areas these selfDefence organisations were imposed by military forces on the rural communities as a counterinsurgency strategy (Fumerton 2001). Therefore, while Peasant Rounds emerged from within the communities as organizations having a quasi-police role, the origins of Peasant Self-Defence Organisations are more related to the state's anti-guerrilla strategy. This has meant that foreign donors and NGOs have often seen the Peasant Self-defence Organisations as 'paramilitary' groups (Fumerton 2001), while Peasant Rounds are viewed as legitimate grassroots organisations that have actually evolved to be in charge of general community well-being. In turn, caring for the local environment is part of the duties of the Peasant Rounds (INRENA and CIMA staff, personal communication).

Also, in part II, section 2, of the PNCAZ's Management Plan -Strategies to Implement the PNCAZ's Management Plan- the Acuerdos Azules (Blue Agreements) were presented as a key management tool (section 2.4 of the Management Plan). These Acuerdos Azules are part of the second management stage -the implementation phase-outlined in Figure 1.3. The rationale behind these Acuerdos Azules was to involve communities in the protection and caring of the National Park. To do so, communities were asked to sign an agreement to

\footnotetext{
${ }^{3}$ The Shining Path was a Maoist-inspired guerrilla organization that emerged on the 1980s in the Peruvian department of Ayacucho. The organization was almost extinct by 2000 (Fumerton 2001).
} 
commit to being involved in the caring of the Park in exchange for technical support and environmental education programmes and workshops (INRENA 2006).

Finally, as a mean to apply of the monitoring stage (see Figure 1.3), the Peruvian Law of Natural Protected Areas (Law No 26834, article 15) requires that every protected area should have a Management Committee (Comité de Gestión del Área Protegida). Management Committees consist of " Local Governments with jurisdiction over the Natural Protected Area; as well as representatives of public and private sectors, local organizations developing their activities around the protected area, and local people organized through participatory mechanisms that have been established for this purpose." (Article 6 of the Directorial Resolution No 001-2001-INRENA-DGANPFS). All those actors are to be invited to participate by the Head of the protected area. These Management Committees are to be approved by the government agency -INRENA- and must be comprised of at least five members. The idea behind the Management Committees is "to foster a participatory management of the Natural Protected Areas, in order to contribute to the preservation of the National Heritage and the sustainable development" (Directorial Resolution No 001-2001INRENA-DGANPFS). According to the objectives of the Management Committee, this institution is supposed to support and collaborate with the management and administration of the Natural Protected Area. The Head of the protected area, or the General Directorate of Protected Areas, determine the issues to be addressed by the Management Committee in meetings held at least twice a year. 


\section{Chapter Two: Methodology}

\subsection{Study Area Description}

The research project was done in the northern buffer zone of the Cordillera Azul National Park (Parque Nacional Cordillera Azul -PNCAZ) in Peru (see Figure 2.2). The Park is located in central Peru (see Figure 2.1) between the Huallaga and Ucayali rivers, and it spans four political departments: San Martín, Loreto, Huánuco and Ucayali (see Figure 2.1). The Park contains the largest remaining lower-montane forest in Peru (INRENA 2006). Also, the PNCAZ is located within the Tropical Andes hotspot, considered to be one of the leading hotspots in terms of endemic species/area ratios of both plants and vertebrates (Myers et al. 2000).

This study focused on the perspectives of three main stakeholders-CIMA, INRENA, and local communities. The majority of the interviews of CIMA and INRENA officials were done in the city of Tarapoto. This is the largest city in the Department of San Martin with a total population of 68,295 (INEI 2007). The surveys were done in three local communities:

Chambira, Selva Andina and Santa Rosillo, with 50, 30 and 40 households respectively (see Figure 2.2) (CIMA staff, personal communication). Most families rely on slash-and-burn agriculture, growing crops for subsistence and coffee for sale, but some also have cows, pigs and chickens. Also, many community members, especially from Santa Rosillo, depend on hunting and fishing for subsistence. 


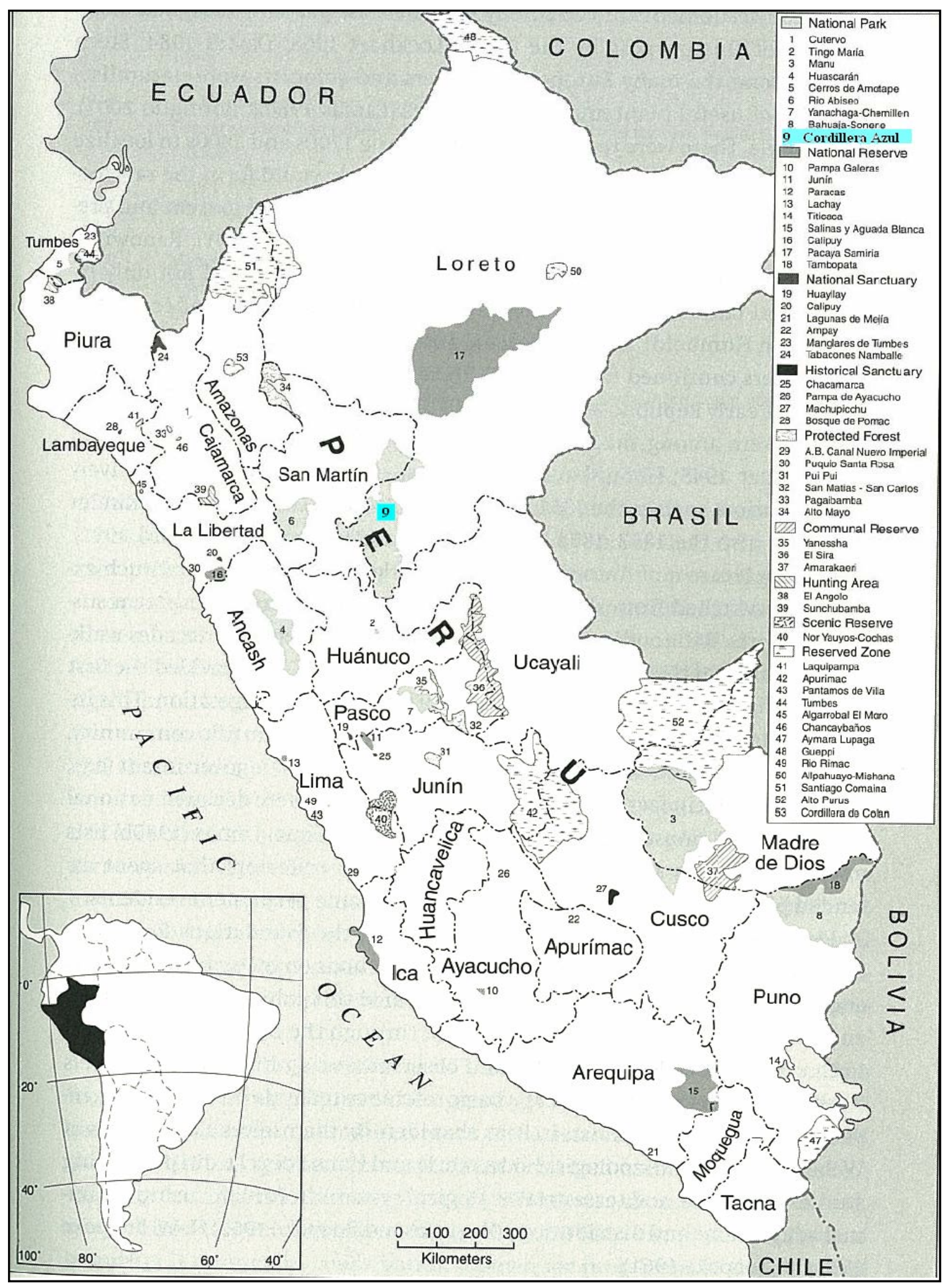

Figure 2.1: The Location of the Cordillera Azul National Park, showing political departments and the other Peruvian Protected Areas.

(Adapted from Young \& Rodríguez 2006). 


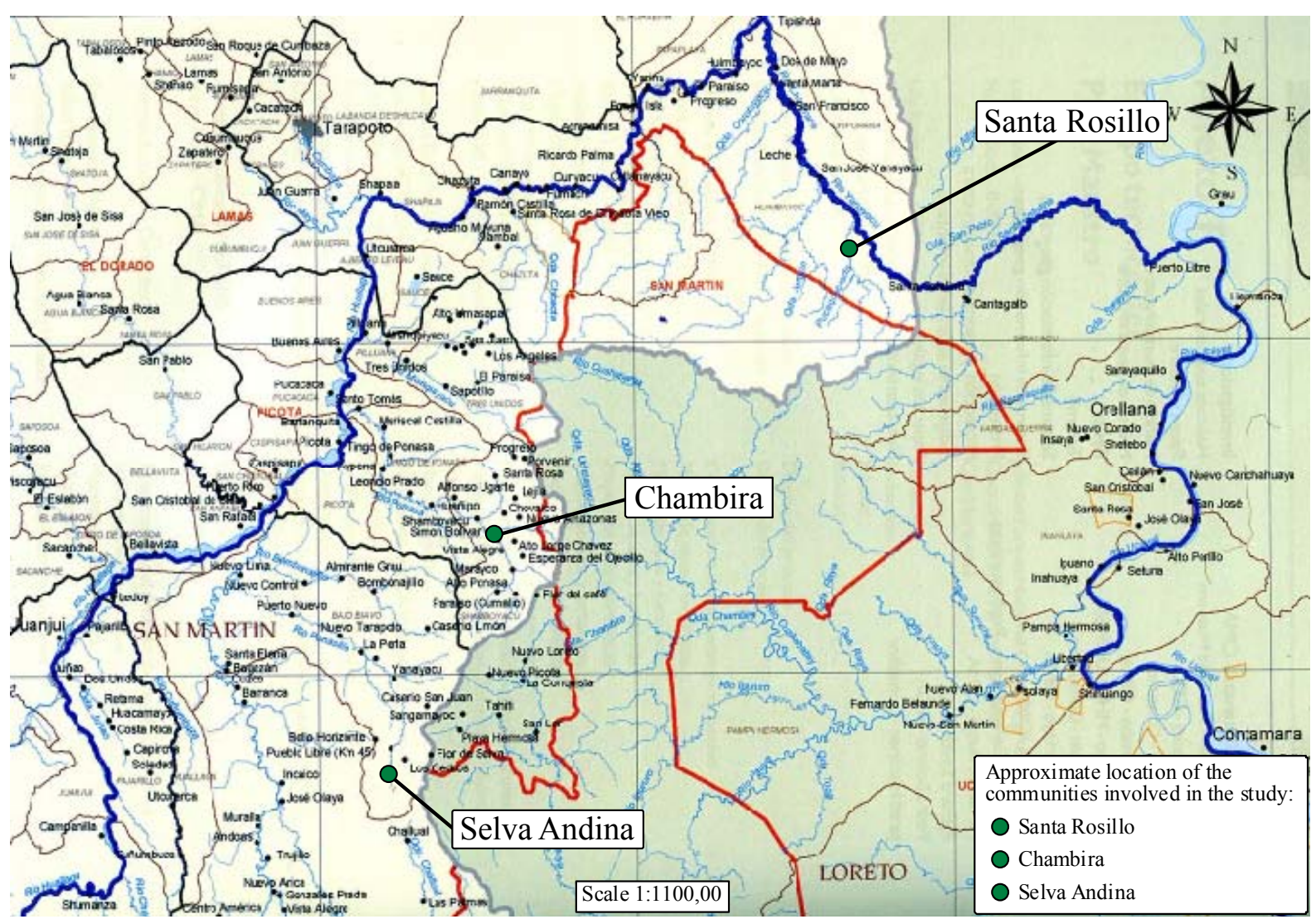

Figure 2.2: The location of the three communities involved in the study. (Modified from

INRENA 2006). Red line indicates the Park's boundary; dark blue line highlights the boundary of the main buffer zone.

\subsubsection{Communities’ inhabitants: Indigenous, Naturales and Immigrants}

According to INRENA (2006), inhabitants of the buffer zone communities can be classified under three different categories: Indigenous people (referred to locally and by INRENA as "nativos") are those people who have been living in the area for at least four generations. Naturales are those people who were born in the same Department as the community they now live in, but they have not been living in the community for more than three generations. Finally, immigrants have moved to the buffer zone communities in recent years (no more than one generation).

These categories are subjective, and within each category there is a great deal of variance. For instance, a natural from San Martin Department when compared with another natural from Ucayali Department would probably have very few commonalities; in fact, there would be as many differences between them as there would be with an immigrant from Cajamarca or Piura Departments. Nonetheless, in the absence of a better categorization, as well as for practical reasons, I decided to follow this locally employed demographic classification. 


\subsubsection{Site Selection}

When choosing focal communities I followed the recommendations of the local NGO managing the Park - CIMA Cordillera Azul - and from Ruben M. Paitán, the Head of the Park. Two months before starting my study, I worked as a volunteer for CIMA. This gave me a better understanding of the area and the Park's management. Also, it allowed me to develop a closer relationship with the people working for the NGO in Tarapoto, as well as with those working for the government agency - INRENA. The advice of both CIMA and INRENA staff made my approach, and the trip itself, to these communities easier and safer. My position as a former CIMA volunteer may have led to some bias when I collected and analysed the data. To avoid this, I emphasised to potential informants that I was not working for CIMA and explained how my role differed from that of CIMA's managers. Also, I chose three communities that I did not visit during my work with CIMA.

Ethnicity appeared to be an important factor influencing the use of natural resources (INRENA 2006). I chose three communities that provided a mixed sample of indigenous, naturales and immigrants. Consequently, I chose one community where the majority of the residents were naturales (Santa Rosillo), one community with half of the population naturales or indigenous and half immigrant (Chambira), and finally one community where the majority of the inhabitants were immigrants (Selva Andina). When deciding which communities to work with, I controlled for the size of community, distance to the Park, and ease of access to communities. I chose communities with 30-50 households for sampling convenience. This limitation may introduce some bias in the study as communities with more inhabitants may lead to different observations of the perceived levels of participation. Also, I chose some of the closest communities to the PNCAZ's boundary as these communities would be the most affected by the Park's creation. Finally, I also tried to work with communities where outside organisations, especially CIMA and INRENA, had not a very strong presence, so informants would be less likely to hide their opinions about the National Park or its management.

Hence, the three communities selected were comparable in terms of size and distance to the boundary of the Park. However, CIMA and other NGOs have a strong presence in Chambira (due to the fairly easy access to the Shamboyacu sector, CIMA and other outside organisations have a strong presence in most of the communities of this sector), though probably less important than in other communities in this area. Since the inception of the park, CIMA has been working in Selva Andina, although the work intensity has not been 
constant through the years. Finally, in Santa Rosillo, CIMA worked for some time during the Park's establishment and then stopped working. A new extension agent has been recently (in 2008) assigned to work in that sector.

\subsubsection{Brief Description of each Community}

Chambira is the largest community of the three chosen. The community has approximately 267 inhabitants and is located in the Shamboyacu sector ${ }^{4}$, between 200 and 400m (INRENA 2006). Chambira has access to electricity and piped water, and there is also a primary school in the community. Half of the inhabitants are immigrants, whereas the rest are either naturales or indigenous. Chambira is about 1.5 hours walking distance to the Park, with a Park guard post at the entrance to the National Park.

Selva Andina is located in the Bajo Biavo sector (see Appendix 1) between 800 and $1000 \mathrm{~m}$ (despite the altitude differences, all the communities are located in lowland moist tropical forest). It has approximately 250 inhabitants with almost all families coming from other Peruvian Departments (immigrants). In this community the access to electricity is limited to a generator, and they pipe water from a nearby river to a community tap. Selva Andina is located about 20 minutes walk from the Park. Near the Park boundary there is a Park guard centre (about ten minutes walk from the community). Park guard centres are bigger than guard posts, with two or three Park guards compared to just one Park guard at a post.

Finally, Santa Rosillo is the most remote community of the three, and it is located in the Huimbayoc sector (see Appendix 1), between 0 and 200m. Most of the inhabitants are naturales. There is no access to electricity and water needs to be collected from the river nearby. Santa Rosillo is about one hour walking distance to the Park, and about three hours walk to the closest Park guard centre.

\subsection{Research Design}

\subsubsection{Arriving at the Communities}

Even though I am a native Spanish speaker, my accent made it clear to everyone that I was a foreigner. I was always aware of the potential bias my accent and outsider status could create, especially to the questionnaire respondents, due to the deference effect. Respondents may not honestly answer questions, but rather say what they think the interviewer wants to hear

\footnotetext{
${ }^{4}$ This is a CIMA's working sector, based on the political division and the local physiography (see Appendix 1).
} 
(Bernard 2002). Thus, from the beginning I always tried to emphasise that I was a postgraduate student, doing a study related to the PNCAZ. I also mentioned that I was not working for anyone, and it was really important for my study to get the respondent's own opinions.

Also, to avoid bias I did not visit any of these three communities while working with CIMA as a volunteer. I always arrived for my first visit walking alone on Sundays, as these days are usually set aside for all the inhabitants to stay in the community for communal meetings or to play soccer in the afternoon. I wanted all community members to see that my study was independent and not affiliated with other organisations or individuals active in the region.

\subsubsection{Qualitative and Quantitative Methods.}

This study takes a pragmatic theoretical perspective, in which the focus is on the problem itself rather than the method. Thus, the intended end is what mainly drives the research. Also, a pragmatic paradigm fosters a pluralistic approach to gain a better understanding of the problem (Cherryholmes 1992; Creswell 2003). Also, this thesis employs a mixed methods approach, because triangulating methods can help neutralize biases inherent to any single methodology (Bernard 2002; Creswell 2003). The study started with a literature review in order to identify the main factors affecting participatory approaches in community conservation. Then a mixture of quantitative (a questionnaire) and qualitative (semistructured interviews) methods was used to collect data simultaneously during the study.

\subsubsection{Ethical Issues}

I obtained approval from the Human Ethics Committee of Victoria University of Wellington (Approval number: 15,580). All the survey respondents were informed of the objectives and purpose of the research before I started the survey. Also, I had to first gain permission from community authorities to stay in each community and carry out my research. This study was also done with the written permission of the Head of the Park (see Appendix 2 ) and the agreement of CIMA. The ten interviewees (see details on method below) all read and kept the Information Sheet of the research, and agreed to participate in this study (see Appendix 3). They also granted permission for me to use the results of this research, including their names and quotations for my Master's thesis and other potential publications.

Informed consent was verbally obtained before I started the questionnaire with community members (see details on method below). Obtaining a written consent to participate in this 
research was not feasible for the following reasons: First, it would increase the duration of the questionnaire (which would significantly diminish people's willingness to participate). It was also likely that several of the informants were illiterate, and most importantly it would also undermine the anonymity of the questionnaire. However, I emphasized it was for a foreign university study, that they could withdraw the survey at any time, or refuse to answer any questions they did not want to answer, and stressed that it was quick and completely anonymous. Before starting the questionnaire I always tried to avoid mentioning the PNCAZ since that would directly interfere with the first section of the questionnaire (see Appendix 4).

\subsection{Methods}

\subsubsection{Semi-structured Interviews}

Semi-structured interviews lasted approximately one hour. All 10 interviews were based on the use of an interview guide (see Appendix 5) which ensured that the main topics were covered, but still left some space to follow new leads (Bernard 2002) in case other relevant issues arose during the interview.

Given that this research focuses on the different main stakeholders' perspectives of the Park's management, I decided to interview CIMA experts as well as some INRENA officials (see Table 2.1). There were two main factors when deciding whom to interview. On the one hand, I was interested in having the points of view of those who were involved in the establishment of the National Park. Thus, I had interviews with former -mostly from the upper-level management positions- CIMA employees, the former Head of the Park, and a couple of Park guards who have been working in the PNCAZ since its establishment. On the other hand, I also interviewed those who might have a greater influence now and in the immediate future of the Park's management. In some cases it was possible to interview people who fit in both the categories (being involved during the Park's creation and having some influence in the Park's current management), such as Alaka Wali from the Field Museum of Chicago and Ruben Paitán, the current Head of the Park and a former CIMA employee.

Because my supervisor, Dr Michael Gavin, had previously conducted research in the PNCAZ, he provided me some key contacts at CIMA, and ideas as to the main stakeholders I could interview. Also, in forming the list of people to interview, there was significant input from Miguel Macedo (CIMA's head of the extension section). I also applied the snowball 
sampling technique (Bernard 2002), that in many cases confirmed the list I had in mind.

Table 2.1 provides a list of those experts interviewed and their professional affiliations.

Table 2.1: List of interviewees.

\begin{tabular}{|c|c|c|}
\hline $\begin{array}{l}\text { Name of the } \\
\text { interviewees }\end{array}$ & Organisation & Affiliation \\
\hline $\begin{array}{l}\text { Luis F. Benites } \\
\quad \text { Hidalgo }\end{array}$ & INRENA. & Former Head of the Park. \\
\hline $\begin{array}{l}\text { Rubén Mark Paitán } \\
\text { Santillán }\end{array}$ & INRENA. & Current Head of the Park. \\
\hline $\begin{array}{l}\text { Dave G. Pogois } \\
\text { Loayza }\end{array}$ & CIMA- Cordillera Azul. & PNCAZ Programme Director. \\
\hline $\begin{array}{l}\text { Miguel O. Macedo } \\
\text { Bravo }\end{array}$ & CIMA- Cordillera Azul. & $\begin{array}{l}\text { Head of CIMA's extension } \\
\text { section. }\end{array}$ \\
\hline $\begin{array}{c}\text { Fernando B. Rubio del } \\
\text { Valle }\end{array}$ & CIMA- Cordillera Azul. & $\begin{array}{c}\text { Former Head of CIMA's } \\
\text { protection team. }\end{array}$ \\
\hline Alaka Wali & $\begin{array}{l}\text { The Field Museum of } \\
\text { Chicago. }\end{array}$ & $\begin{array}{l}\text { Director of the Center for } \\
\text { Cultural Understanding and } \\
\text { Change (CUCC). }\end{array}$ \\
\hline $\begin{array}{l}\text { Miguel H. Vásquez } \\
\text { Salazar }\end{array}$ & CIMA- Cordillera Azul. & $\begin{array}{l}\text { Head of the extension agents } \\
\text { team. }\end{array}$ \\
\hline $\begin{array}{l}\text { Andres Cenepo } \\
\text { Chashnamote }\end{array}$ & INRENA. & $\begin{array}{l}\text { Park guard and local } \\
\text { community member. }\end{array}$ \\
\hline $\begin{array}{c}\text { Adler Shapiama } \\
\text { Tangoa }\end{array}$ & INRENA. & Park guard. \\
\hline Lily Rodríguez ${ }^{5}$ & CIMA- Cordillera Azul. & $\begin{array}{l}\text { Former CIMA President } \\
\qquad(2002-2005)\end{array}$ \\
\hline $\begin{array}{l}\text { Rudy A. Valdivia } \\
\text { Pacheco }\end{array}$ & INRENA's Intendancy. & Official. \\
\hline
\end{tabular}

${ }^{5}$ Despite having the same -first- surname we are not relatives. 


\subsubsection{Face-to-face Questionnaire}

I used a face-to-face structured questionnaire to survey local community members. There were many reasons to choose a face-to-face structured questionnaire instead of selfadministered questionnaires. For one, because some of the respondents were illiterate, the face-to-face method allowed me to confirm that participants understood the questions. Also, given that I was interested in heads of households' perceptions about Park management, it was crucial to have their opinions as quickly as possible to avoid any bias due to informants discussing my questionnaire questions. So by using a face-to-face questionnaire I could make sure that the questionnaire was answered individually. Before collecting data in the three focal communities, the questionnaire was piloted with some of CIMA's extension agents and members of the following communities: Nuevo Loreto, Sangamayo and Huimbayoc.

The questionnaire had four sections (see Appendix 4). The first section had questions to test knowledge of the Park. The second section was related to Objectives 1 (examine the levels of local participation at different stages of the Park's management) and 2 (examine the possible barriers to more participation in the PNCAZ) of my thesis. This part of the questionnaire had questions related to attitudes towards participation and perceived levels of participation, as well as questions about relationships with Park staff. In the third section there were questions about respondents' perceived benefits and costs arising from the Park relating to Objective 3 (examine the relationship between locally perceived levels of participation and locally perceived costs and benefits stemming from the PNCAZ) of the thesis. The last section had socio-demographic questions, which also contributed to Objective 2.

The questionnaire was administered early in the morning (6-8 am, before people went to work to their fields) and in the afternoon (5-7 pm, when people came back from working) to minimise interference with daily activities in the households I sampled. I conducted the questionnaire as far away from other potential respondents as possible in order to prevent them from overhearing the questions. Also, I only sampled permanent residents of the community and households within a 15 minutes walk from the community centre (very few houses were farther away than 15 minutes walk, and community members living that far away from the centre of the community were not as involved in the community decisionmaking).

All the participants were randomly selected, and I tried to sample as many households as possible in each community (58\% of the households in Chambira, $73 \%$ in Selva Andina, and 
$57.5 \%$ in Santa Rosillo). Six people declined to participate, most of them claimed not to have enough time for answering the questionnaire. Due to time constraints, I was only able to survey one person per household. In nearly all cases, the households I approached selected the man as the head of household to be surveyed.

\subsection{Data Analysis}

Given that (quantitative) data were not normally distributed, I used Spearman's correlation test to analyse the relationship between different variables. Also, to evaluate the significance of each of the answers (the five possible options comprised in the Likert scale) to a particular question I used the 95\% confidence intervals. In those questions where two options (e.g., Agree and Disagree) had overlapping confidence intervals (showing a not significant difference between the two options) I further tested each option's significance against the other with a Pearson's chi-square test (Field 2005). Lastly, I ran a logistic regression analysis with the intention to examine the extent to which the different variables studied in this thesis were influencing the locally perceived participation levels.

Next, I compared and contrasted community people's perceptions with conservationists' opinions. In doing so, I used qualitative data from both the questionnaire's open-ended questions and the semi-structured interviews. Quotes have been translated to English and all have been edited to some extent, trying to avoid false starts or filler words (Bernard 2002). The open-ended questions allowed me to have a more in depth analysis of the results obtained from the questionnaire's qualitative data.

Questionnaire and semi-structured interview data analysis was carried out in a way that results were grouped within the main factors that the literature identified as variables affecting community participation in conservation management. Also, I followed a constant comparative analysis in examining the semi-structured interview data (Corbin \& Strauss 2008). In doing so, I coded data by comparing the similarities and differences of themes arising in each interview. Those themes that were conceptually similar were grouped under five categories:

1. Views of community participation.

2. Perceptions of levels of community participation.

3. Perceptions of communities' perceived benefits and costs.

4. Perceptions of conservationist-communities relationship.

5. Perceptions of communities' acceptance of the PNCAZ. 


\section{Chapter Three: Results}

\subsection{Chapter Introduction}

This chapter presents information from ten semi-structured interviews, as well as questionnaire data. Although 74 people answered the questionnaire (see Table 3.1), one respondent stated that he did not know about the existence of the PNCAZ, hence results are derived from a total of 73 informants.

Table 3.1: Number of participants per community.

\begin{tabular}{|c|c|c|c|}
\hline & $\begin{array}{c}\text { Approximate } \\
\text { number of } \\
\text { households }\end{array}$ & $\begin{array}{c}\text { No of heads of } \\
\text { households that } \\
\text { participated }\end{array}$ & $58 \%$ \\
\hline Chambira & 50 & 29 & $73 \%$ \\
Selva Andina & 30 & 22 & \\
\hline Santa Rosillo & 40 & 23 & $57.5 \%$ \\
\hline
\end{tabular}

The chapter is divided into three main sections. Each section relates to one of my thesis objectives. Thus, the first section presents results related to my first objective, the second section is related to my second objective, and the last part of this chapter relates to the third objective of this study. 


\subsection{Levels of Participation at Different Management Stages}

The first objective of this study was to examine the levels of local participation at different stages of the Park's management. The management of the PNCAZ can be divided into three main stages (see the introduction chapter for details on PNCAZ's history):

1) The establishment of the PNCAZ (2001-2002). This stage comprises the Rapid Biological Inventory and the legal processes to create the protected area.

2) The first six years (2002-2008) of the Park's management. During this stage the Park was managed under an agreement (Convenio) between CIMA and INRENA. This management phase involves two different steps:

2.1) the development of the park's first management plan (2002-2004). This period includes the application of the first Mapeo de Usos y Fortalezas (Mapping of Social Assets and Resource Use -MUF).

2.2) the implementation of the Management Plan (2004-2008). This period includes the establishment of Acuerdos Azules (Blue Agreements).

3) The current management stage (2008-present). This stage began with the granting to CIMA of the Total Management Contract of the PNCAZ. It involves the application of the (2008) MUF for the development of the new Management Plan.

Thus, results of levels of participation are presented for each of the three periods in which the PNCAZ's management can be divided. The three PNCAZ's management stages however, do not exactly correspond to the generic management stages outlined in section 1.1.2 (see Figure 3.1). 


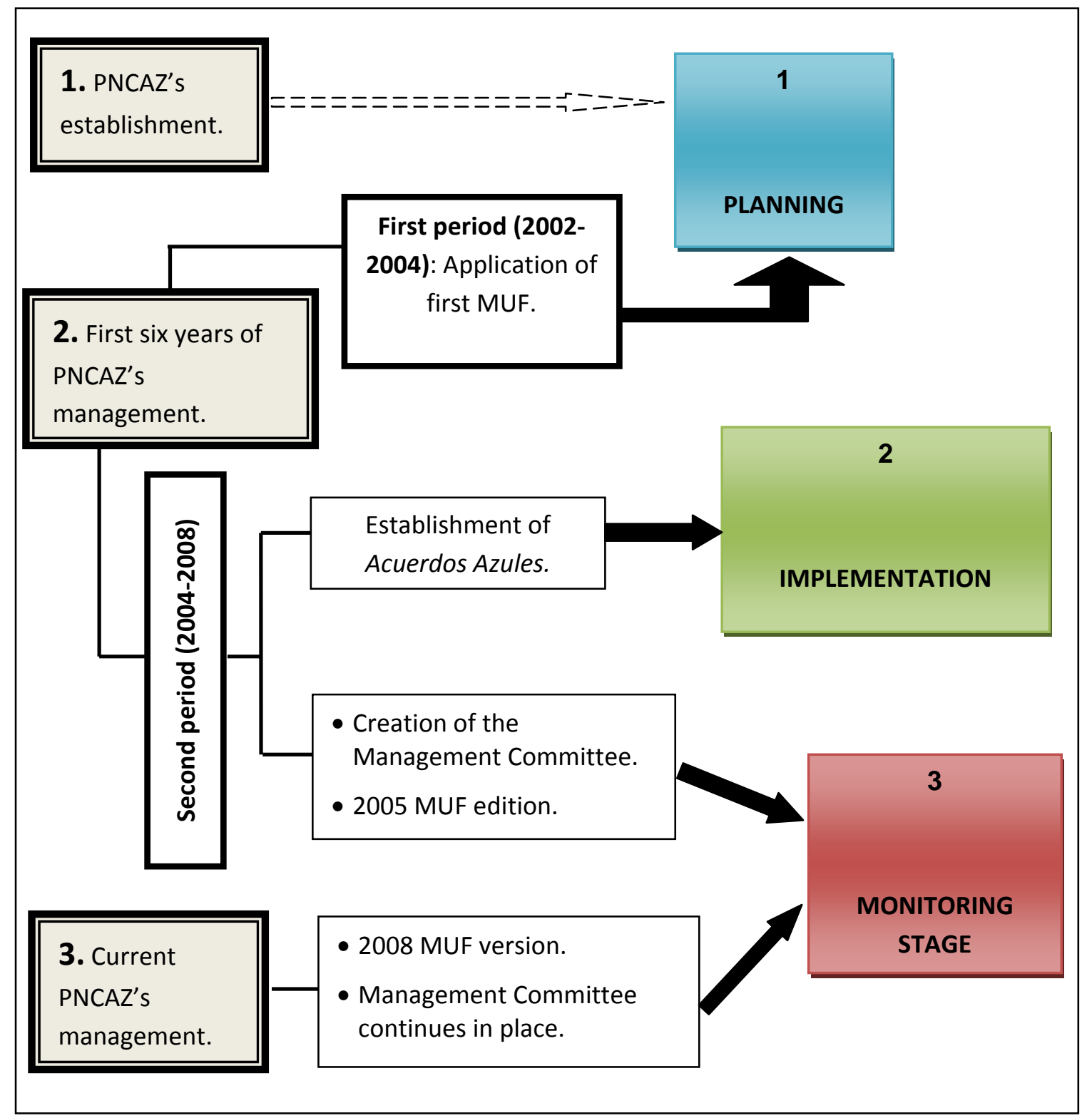

Figure 3.1: The PNCAZ's management stages in the generic management stage framework.

Figure 3.1 illustrates that some planning was necessary to create the Park, however a planning phase as such would be more clearly represented in the development of the PNCAZ's Management Plan. Also, the implementation of the PNCAZ's Management Plan would then relate to the 'implementation phase' of the generic management stages. Finally, the Management Committee meetings as well as the 2005 and 2008 MUF editions would all correspond to the 'monitoring phase'. 


\subsubsection{Perceived Levels of Participation in the Park’s Establishment}

All of the interviewees that were involved in the Park's establishment agreed that it was not very participatory. Some interviewees, such as Lily Rodriquez (Former CIMA President), mentioned that communities were at least consulted about the establishment of the PNCAZ, and that participation may have been limited by time: "[Communities] were not involved too much in the Park's establishment. We had to rush to establish the Park, I mean it is not easy to establish a Park and we had a window of time and political will of the minister to establish the Park and we took it to the fullest. There, the limiting factor was the time...”

As outlined in section 1.4.1, there was in fact a narrow window of political opportunity that led to a rapid succession of events concluding with the PNCAZ's establishment. Other interviewees, such as Luis Benites (Former Head of the Park) were even more sceptical, pointing out that participation varied geographically. Benites indicated that many communities were only informed about the fact that a National Park was going to be established, and that many other communities did not participate at all: "I think that those who are familiar with the [process of the Park's] establishment are aware that it was not too participatory. It was participatory in some areas like Pisqui, Shamboyacu, or Chazuta. But there was almost no [community] involvement in the part of Tocache and Aguaytía."

Fernando Rubio (Former Head of CIMA's protection team) expanded on the sentiments put forth by Rodríguez and Benites, noting the logistical and legal barriers to full participation in the Park's establishment:

In the establishment process there were some workshops to explain to the people [what a National Park is], but that was almost a formality. I mean you cannot have a very long process while having a consultation with all the people, because when you have finished with the 300 towns, then there is no Park... So, there was some [community involvement], but many [other communities] did not know. I think most of [the communities] are now wondering why they were not asked. And that is so because those who decide are not the communities, who decides about the establishment of a protected area is not the community, it is the State.

In line with this perception of the Park being established in the shortest period of time as possible was the opinion of Miguel Macedo (Head of CIMA's extension section): 
[Community participation in the Park establishment] was low, very low... There was not too much participation in the consultation at the community level[...] In Peru always, well, not only in Peru, but I guess that is at a worldwide level, there is always a rush to create things and no matter what the previous processes are, they are a waste of time[...] The Park was established and then communities were told: 'Now that we have the Park, I am going to explain to you what a Park is so you can criticise it or say that you support it.'

Thus, some interviewees made it clear that it was a decision in which communities had no voice. Three main themes appear to have influenced local participation in the PNCAZ establishment:

1) Participation might have been restricted by the need for expediency in the conservationists' agenda.

2) The political process needed for the establishment of a protected area might have also limited communities' participation.

3) Participation varied geographically.

Therefore, based on the background provided by the interviewees, it is not surprising that most of the community members surveyed did not know how their community was involved in the Park's establishment. Nearly half the respondents (32 of 73) had no idea how their community was involved with the Park's establishment. Another 14 informants discussed reaching an agreement, or that the community was united in supporting the Park's establishment. Only nine respondents mentioned that their communities were consulted in a meeting (two of them mentioned the MUF).

\subsubsection{Levels of Participation in the first six years}

The majority of the interviewees were to some extent critical of the level of participation achieved. Although many argued that the PNCAZ was managed under a participatory approach, and hence, the Park had levels of participation much greater than many other Peruvian protected areas; they were aware that participation levels could be improved. For instance, Ruben Paitán (Current Head of the PNCAZ) stated: "We are trying wherever possible to involve as many actors as we can... I do not think it is totally participatory at the 
level we would like it to be. But given our limited resources and given the context we operate in now, [the Park] has quite a high level of participation compared with other protected areas in the system [the Peruvian Protected Areas System, SINANPE].” Alaka Wali (Field Museums' Director of the CCUC) expanded on the opinion put forth by Paitán, and pointed out that communities' participation in the management varies depending on the type of decisions that were covered.

I think that it is much more participatory in its approach than anything I have read about it in other Parks [...] In some things it is a more top-down [approach], depends on what we are talking about. Decisions about what happens inside the Park itself, for example, or where we put the Park guard post ... This is almost (entirely) decided by the Park team. There is very little consultation about that with the community... But in other kinds of things, aspects of the Park management like where were the resource use zone is supposed to be, how much can people meet their resource needs within the Park, all of that, there was much deeper consultation. So, the voice of local people is included in the Management Plan. They were able to guide decisions that were made about those kinds of things. So it is a mixed bag, depends on the component[...] It has been more on the participatory side, it is not quite an empowerment for the most part yet, but it is moving towards empowerment in some areas. But I think we have a long way to go.

- Alaka Wali (Field Museums’ Director of the CCUC).

Fernando Rubio (Former Head of CIMA's protection team) was a bit more critical of the level of participation achieved: "I do not think [it is participatory management]. There are some efforts being made, but I think there is a whole institutionalism and a sense of the establishment that makes it hard to be able to be participatory.” Miguel Macedo (Head of CIMA's extension section) agreed, and argued that communities should have more participation in the Park's decisions: "I do not think [that it is participatory management]. Some processes have been started where the population is getting involved, such as the volunteer Park guards... But [the community people] do not directly participate in the decision making process, they should be more involved in the management itself."

Conservationists were also critical of the levels of participation reached in the Management Committee. The Management Committee is an institution comprised of public and private representatives that collaborates with the administration of the National Park. However, all 
the experts interviewed were critical of the Committee's status. For instance, Dave Pogois (PNCAZ Programme Director) stated:

I think the Management Committee's function should be at the level of decision-making, especially in policies related to the Park's management. But the Management Committee is not fulfilling that role, and I think we need to empower the Management Committee. I would say that the Committee is working as a supporting body in some activities, and even in this role, the Management Committee has not been very involved. The problem is that the Management Committee has not participated at the level of decision-making.

Fernando Rubio (Former Head of CIMA's protection team) agreed, and also pointed out that there were legal barriers that limited the influence of the Management Committee: "I think the Management Committee only gives recommendations. I would say that the name is still too big for what it really is... I believe it is a good tool, even though it is not legally allowed to have any real influence in the Park's management.” Miguel Macedo (Head of CIMA's extension section) went a step farther stating: "The Management Committee is a hoax; the name should be the Management Supporting Committee. Because the most the Management Committee can do is give some suggestions about the decisions being made about the Park, but the [Management] Committee does not have any direct function in the management of the protected area."

Despite the interviewees' perceptions, community members thought that their communities were participating. Thus, the vast majority of respondents (61 people) thought that communities participated in the Park's decisions (see Figure 3.2). 


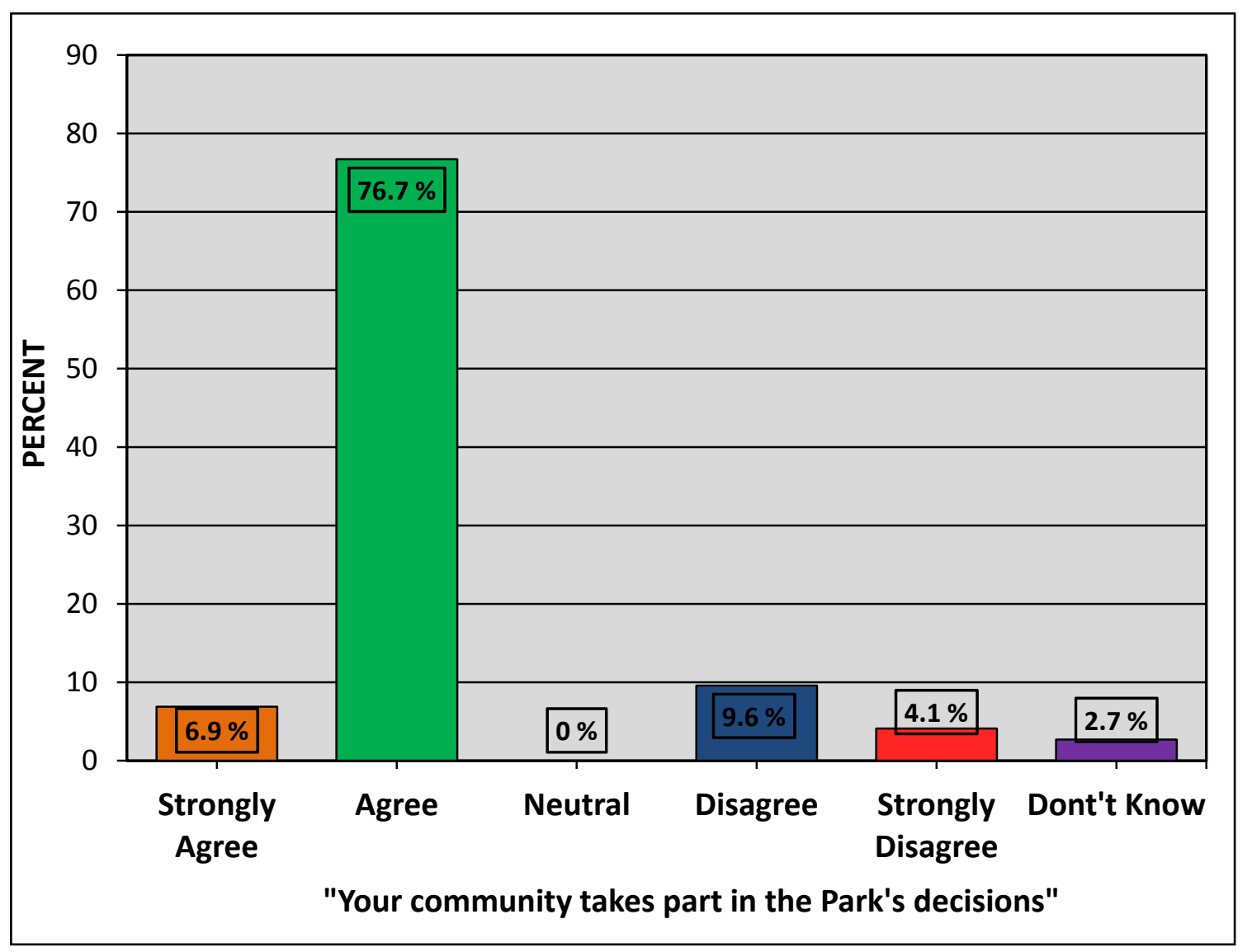

Figure 3.2: Perceptions about communities participating in the Park’s decisions.

In spite of this perceived involvement, people seemed unclear about how their communities were included in the decisions. For instance, when those that thought their communities were participating in the Park's decisions were asked about examples of decisions in which their community took part and how they thought that their community was taking part in the Park's decisions, most of the respondents said that they did not know. Only eight people were able to provide some examples of decisions that their community took part in. The decisions mentioned were principally about the fact that only people from communities in the buffer zone were allowed to hunt for subsistence inside the Park. For example, one respondent mentioned: "It was decided that outsiders could not enter the Park for hunting." And another stated that: "It was decided not to allow hunting for commercial purposes and to take care of the water." One respondent stated that the community were consulted in the determination of the Park's boundary: “The [Park's] boundary was agreed with the communities.” Thus, given the wording of the respondents answers it could mean that informants knew what decisions had been taken, but does not necessarily imply the informant participation in these decisions. 
Also, during this second management phase, the first edition of the MUF was carried out in 53 communities. During that version of the MUF the information was directly retrieved by community representatives called 'community facilitators'. Thus, comments by Miguel Macedo (Head of CIMA's extension section) and other interviewees seemed to indicate that some levels of participation were achieved in the 2003 MUF edition, contrasting their earlier quotes, which did not necessarily imply significant levels of participation. For instance, according to Miguel Macedo (Head of CIMA's extension section), the 2003 MUF meant a significant change -in Peru- in the way communities were involved in the planning of protected areas.

The MUF is a process that the first time it was applied, which was the best edition, involved people from the communities in the information gathering, while [in other protected areas] managers used to only do some workshops around the Park, known as a 'FODA' [strengths, weaknesses, opportunities and threats analysis -SWOT] [...] and then went back [to the communities] and show them the results. Instead, here, we [Park staff] wanted to have more community involvement.

Miguel Macedo (Head of CIMA’s extension section).

Alaka Wali's (Field Museums' Director of the CCUC) comments supported Macedo's ideas on the importance of the 2003 MUF version, and she also expanded on the reasons behind the MUF process:

When we [the Field Museum of Chicago team] had a meeting with CIMA we were told that the standard process for gaining community acceptance of the Park in the Management Plan was to hold six or seven workshops [...] I started to ask questions. So, who gets invited to the workshops? "Well, it is usually authorities of the communities, and they are there for a day or two, and then that is it." And I would say, "that is not participation; it does not get you the voice of underrepresented people in the communities, it does not get you the real ability to understand the ways that people will take ownership of the Park." Because the ultimate goal of that, is that communities feel as they have a role to play, and a stake in the management of the Park. [...] So, I thought that we needed to have more participation, and take longer, and use a more in depth methodology [...] [the 2003 MUF] was a deluxe version of the Mapping [MUF], 
because we had facilitators in each community that spent two months [gathering the information].

Lastly, during this second management stage the Acuerdos Azules were also implemented. The Acuerdos Azules were a management tool used to increase community participation by trying to get communities to commit to helping care for the Park in exchange for technical support and environmental education programmes and workshops. Interviewees' generally felt that the Acuerdos Azules did not work. Some argued that there was a lack of consistency when reaching these agreements. For instance, Alaka Wali (Field Museums' Director of the CCUC) stated: "I do not think we [Park staff] did a very good job of implementing the Acuerdos Azules [...] I think there was a lot of variability in how it was applied; it was not consistently used.” Miguel Macedo (Head of CIMA's extension section) agreed, and noted that a key failure was a lack of consistent application of the Acuerdos Azules concept by fieldworkers who were sent to the communities to establish the agreements:

Although CIMA's work was good, there were not strategies to follow. Basically, the people working here [in CIMA] went to the field and did their work in the best way they could. Thus, you had people that did very specific things with the Acuerdos Azules, while others reached very general agreements [...] The only thing that they [CIMA staff] knew was that everyone in the communities had to sign [the Acuerdos Azules], but there was not clarity about what were the commitments that need to be agreed.

Dave Pogois (PNCAZ Programme Director) expanded on the opinions put forth by Wali and Macedo, noting that the Acuerdos Azules should have been clearer about the duties and responsibilities both sides were agreeing to:

In some places where the Acuerdos Azules were specific in what was agreed, because the Acuerdos Azules were not implemented in all the communities, I think the activities more or less worked. But when the [Acuerdos Azules'] concept was misunderstood, and the Acuerdos Azules were applied without clearly specifying what had been agreed to; signing them without a clear, objective and specific idea, then it did not work. The Acuerdos Azules need to be more specific about what are the commitments assumed by both the communities and the institutions. 
Therefore, based on the background provided by the interviewees, it is not surprising that most of the community people (59 respondents) did not know about the Acuerdos Azules (see Figure 3.3).

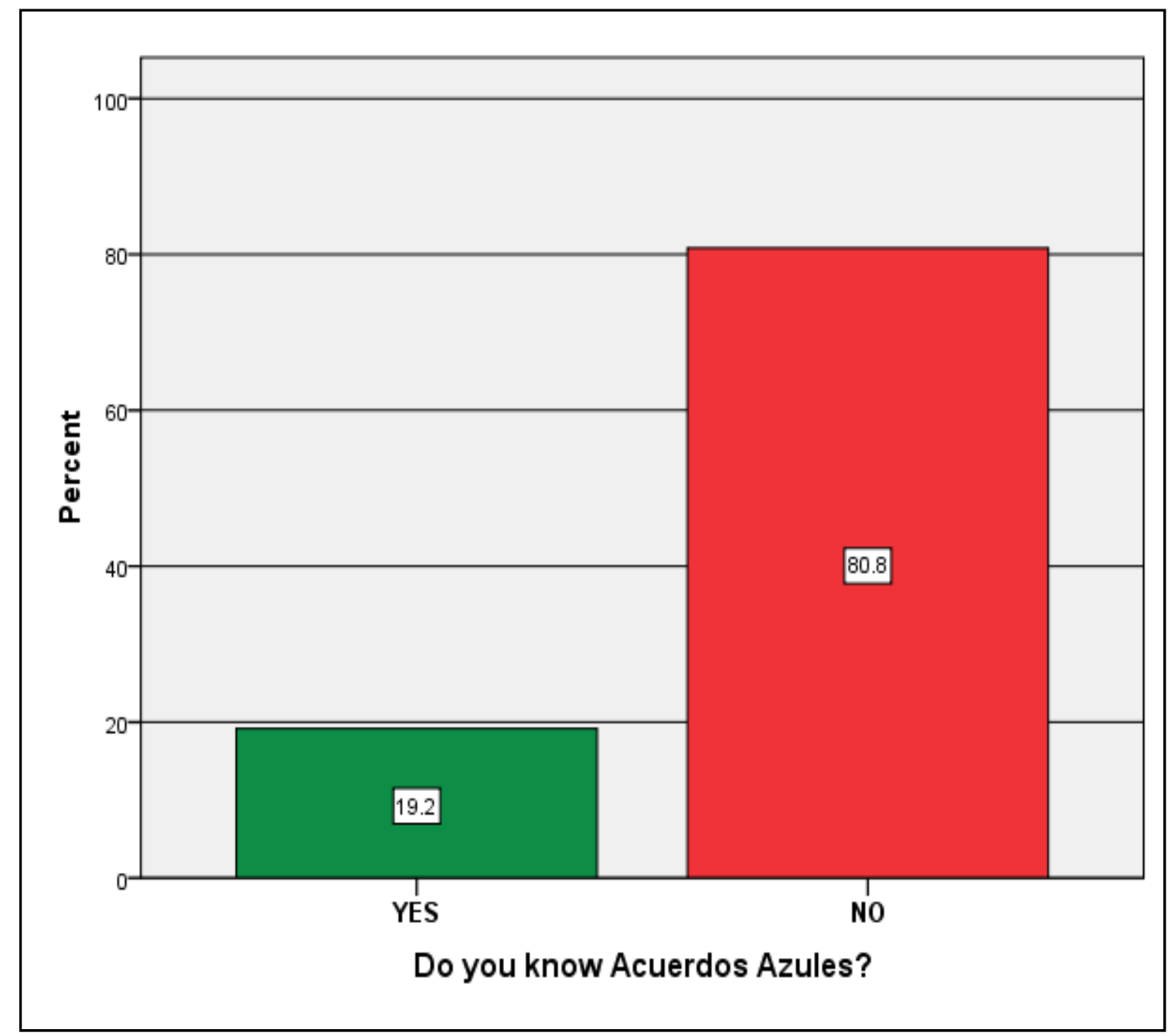

\section{Figure 3.3: Community people awareness of Acuerdos Azules.}

In addition, of the 14 respondents that knew the Acuerdos Azules, 11 thought that these agreements did take into account their communities' needs.

Therefore, it appears that conservationists were critical of the levels of participation achieved during this second PNCAZ's management stage. Even though some interviewees highlighted the participatory levels achieved in the 2003 MUF edition, all the experts interviewed were critical of the Management Committee status and also pointed out that the Acuerdos Azules did not work. On the other hand, community people perceptions were that they were participating in the Park's management, although only a few could offer an example of a decision in which their community was involved. Also, the majority of respondents did not know about the Acuerdos Azules. 


\subsubsection{Current Levels of Participation}

This stage of the PNCAZ's management involves the application, in 2008, of the MUF as part of the new Management Plan development. Also, in this third PNCAZ's management stage, the Management Committee continues in place. Given that this last PNCAZ's management stage has recently started, results about the Committee's role and performance presented in the previous section (section 3.2.2) also apply here.

\subsubsection{Communities’ Perceived Levels of Participation}

To identify local peoples' perceptions of the levels of participation in the current management phase, three different questions were asked in the questionnaire. I started by examining people's perceptions about levels of community participation, and after examined their perceived responsibility in the Park's management.

Results show that over $80 \%$ of the informants agreed or strongly agreed with the statement that local people were involved in the PNCAZ's current management (see Figure 3.4).

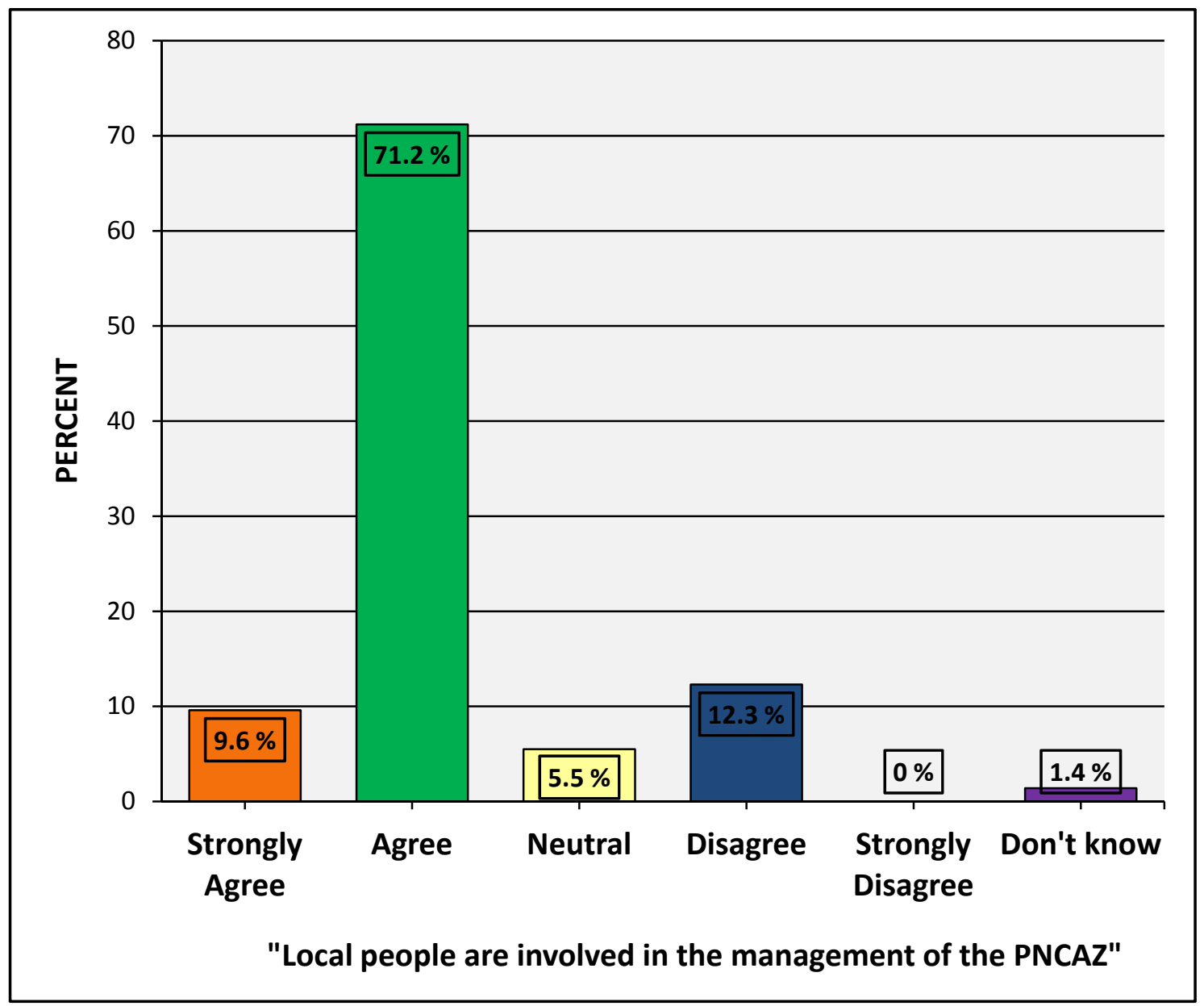

Figure 3.4: Perceived involvement of local people in the Park's management. 
Also, $84.9 \%$ of the local people I surveyed agreed or strongly agreed with the statement that their community was at least partially responsible for the Park's current management (see Figure 3.5).

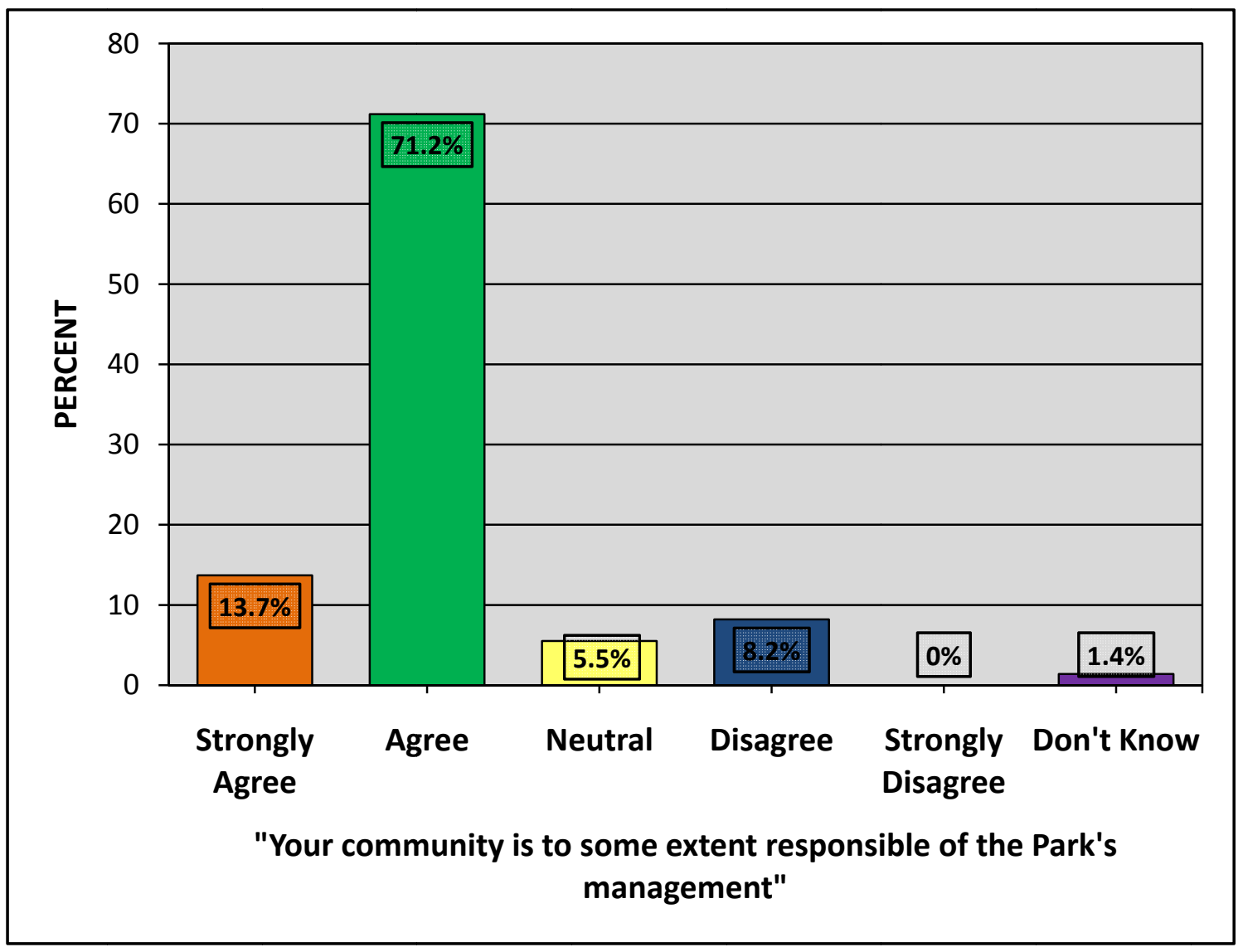

Figure 3.5: Communities perceived responsibility for the Park's management.

Given that the management of a protected area involves many different tasks, I aimed to determine peoples' perceptions about the potential community role in different aspects of the PNCAZ's management. Four main themes appeared when local people were asked what role they should play in the Park's management. The most common response given by 35 people was to help or support the Park guards in the conservation of the Park. This category involved both acting as informal Park guards and limiting the impact of personal resource use. For example one respondent mentioned: “Taking care, not cutting down trees, not burning, making sure that people do not come into the Park for hunting.” The second most common answer (13 people) involved supporting Park staff. For instance, one informant mentioned: 
“Doing jobs when they ask for support. Building tambos ${ }^{6}$ [small huts], for example." The third theme mentioned by 11 respondents was 'reaching agreements', as exemplified by the following quote: "All the community inhabitants agreeing to dialogue with CIMA and INRENA [staff] so they support our community and we [the community] support the institutions." The fourth theme came from nine respondents, who felt that levels of community support should reflect the levels of benefit received from the Park. For example, one person felt that: "[community involvement] should be in accordance to how [the Park staff] treats us [local people].” Or as another informant said: “We [community members] do not receive help or feel a [community] development. That is why I just devote myself to my farm, because I am tired of [false] promises.” There were also five people who said that they did not know.

The majority of respondents therefore, perceived that their communities were involved in the PNCAZ's management. Also, the aspects of the management where respondents saw communities' potential participation were mostly what could be termed as 'fieldwork', rather than in administrative roles. None of the respondents mentioned a desire for more community involvement in the Park's administration, including no discussion of involvement with the Management Committee. These ideas may reflect the modes of participation that have been offered to the communities. As Dave Pogois (PNCAZ Programme Director) mentioned: "Communities in the buffer zone are participating in some activities such as communal surveillance, in work like Peasant Rounds, and support for the Park, but apart from that there is no more participation.” Miguel Macedo (Head of CIMA's extension section) agreed that communities' participation in the Park's management was low: "People are not complaining about not participating. What actually happens is that they think that participating is just helping to take care of the Park."

Given the lack of an established definition of participatory management, interviewees were asked to define participation in the field of conservation management. Some interviewees pointed out that participation was a continuum, and hence, participatory management could vary in levels of participation but still be regarded as participatory. For example, Alaka Wali (Field Museums' Director of the CCUC) stated: "I think you have to look at this whole phenomenon on a kind of continuum, not just one thing is participation, and something else is

\footnotetext{
${ }^{6}$ These huts might be used by Park guards when they are patrolling. It is also possible, that the informant referred to Park signs that are built in the traditional way and using local resources such as the leaves of the Piasaba palm trees (Aphandra natalia) for the tambo's roofs.
} 
not participation. There is a continuum that can define the strategy for management of the resources.” In contrast, Fernando Rubio (Former Head of CIMA's protection team) argued that management is participatory only if the people have the power to shape the decisions being made: "Participation implies to have certain control over the things, not just to intervene, but also having the chance to influence. Those who are taking the initiative of creating this process allow you to also be able to, somehow, make your ideas prevail; and not only ask you about information and that is it, you have participated, thank you."

Alternatively, the definition given by Andres Cenepo (Park guard and local community member) more closely resembled community people's understanding of participatory management (as basically supporting the Park staff or working with them). He viewed community participation as mainly supporting the Park's management: “I understand participation as [the community] being involved in the jobs, being involved in conservation along with the Park guards and CIMA's staff. That they [the communities] are the spokespeople, they are the informers and at the same time, they also have to protect their buffer zone.” Based on this definition, Cenepo felt that the Park was being managed using a participatory approach.

\subsubsection{The 2008 MUF}

In order to develop the new Management Plan, the MUF was applied in approximately 80 communities in the PNCAZ's buffer zone between April and July of 2008. Unlike the first edition of the MUF (in 2003) this edition did not involve community facilitators gathering the information. Alaka Wali (Field Museums' Director of the CCUC) gave a hint of why the data gathering system changed:

Once you have that baseline [from previous MUF's data], then you do not have to repeat it [having community facilitators to retrieve information in each community] all the time, because the information does not change that fast. That is why we [Park staff] thought we could go to the workshop approach with four representatives of each community. These are updates [...] the other difference [with the 2003 MUF] is that now the extension agents are in the communities all the time, so they constantly update the information, and have all of that [information]. 
This decrease in the extent to which communities participated in the MUF, might indicate that participation is affected by issues of expediency with the conservationists' agenda.

Therefore, according to the conservationists opinions, in this third PNCAZ's management stage the Management Committee was still not properly implemented and the 2008 MUF edition was less participatory than in 2003. Thus, the results from most of the interviews seemed to point out that the current management stage might have lower levels of community participation than in the second PNCAZ's management stage. However, community people's perceptions were that they were participating in the PNCAZ's management and also, a significant number of respondents felt that they were responsible -to some extent- for the Park's management. This contradiction between conservationists and communities perceptions of the levels of participation might be explained by the different understanding of what participatory management means.

\subsection{Possible Barriers and Triggers to Participation}

The second objective of my thesis was to examine the possible barriers to more participation in the PNCAZ. Hence, this section presents the results of the different research questions (what are the local attitudes towards conservation? what is the relationship between conservationists and local communities? and, how locally perceived ownership of the Park relates to perceived participation?) related to the second objective.

\subsubsection{Local Attitudes towards Conservation}

Attitudes towards conservation are one of the key components determining people's behaviour (Jacobson et al 2006; Kollmuss \& Agyeman 2002). Therefore, analysing respondents' attitudes towards community participation in conservation might shed some light on whether local attitudes towards conservation are a hurdle to increase participation in the PNCAZ's management. As Figure 3.6 illustrates, 95.9\% of the respondents wanted even more community participation. Given the overwhelming support for more participation, it does not seem that attitudes towards participation are a barrier to more involvement in conservation management amongst questionnaire respondents. 


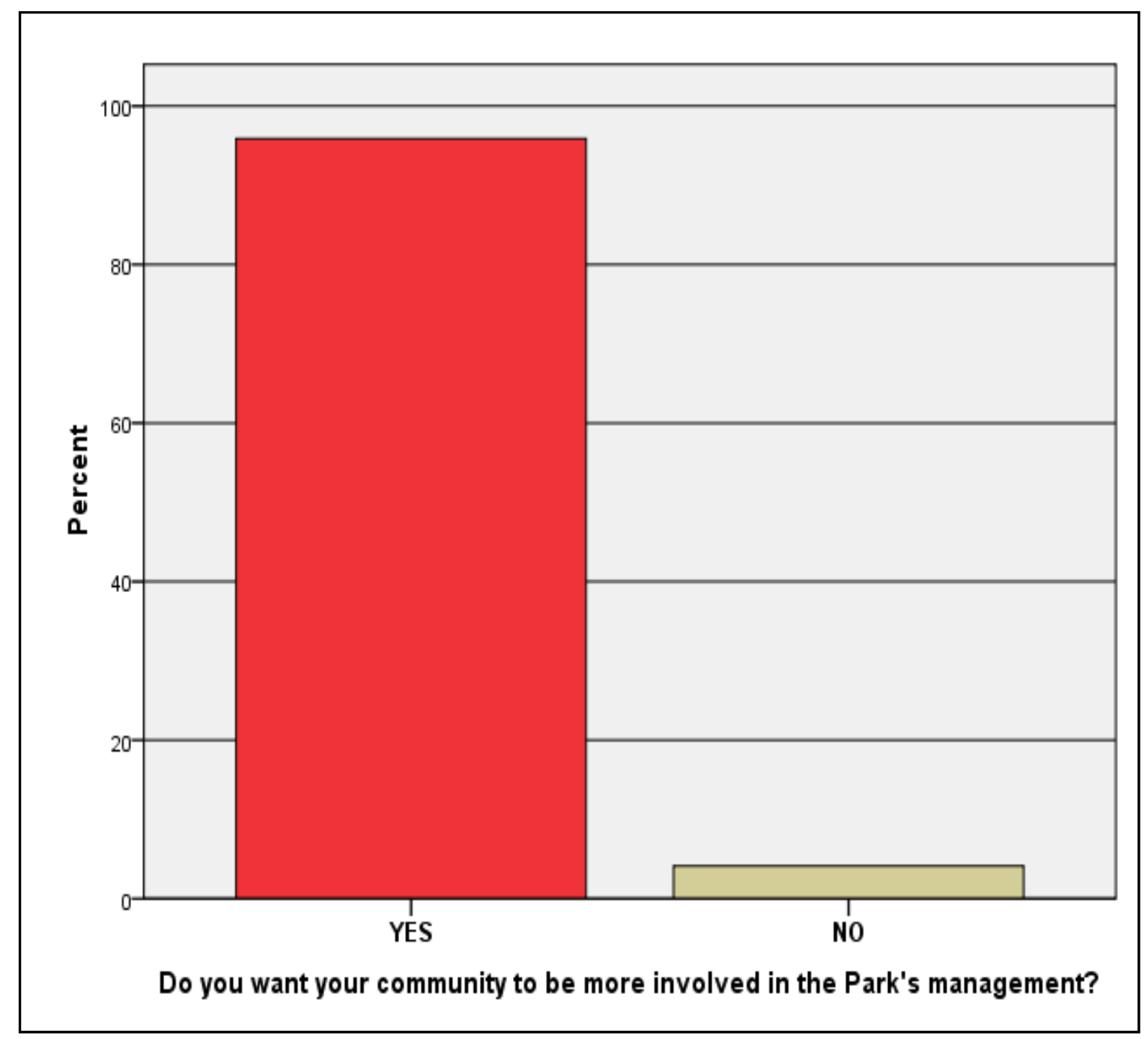

\section{Figure 3.6: Desire for more participation in the management of the Park.}

I categorised the reasons given by respondents about why they were willing to have their communities engaged in the management of the PNCAZ into four main themes. First, 31 respondents mentioned the important role that the Park plays in protecting both ecosystem services, like the need to 'keep the rain' and protect clean water, as well as the value of biodiversity, such as the presence of animals around the communities. The second most common reason stated ( 23 people) was that involvement in the Park's management was good for the community in terms of community development. One informant stated: "because it is good for the community"; and another respondent mentioned that being involved in management can help them: "to be more developed as a community, so it [the community] is more beautiful". The other main two reasons argued were: to increase knowledge, and due to the empowerment outcomes of participation. The category 'to increase knowledge' encompasses eight respondents' statements, such as: “Because we [community members] have a lot to learn about [the Park], and our children will also learn to appreciate what we 
have." Also two respondents provided statements that can be classified under the idea of 'community participation as an empowerment process.' For instance, one informant stated: "Because as a native community, we want to own our territory." This statement might indicate that the respondent viewed community participation in conservation as a mean to obtain (community) political gains. In line with this statement, another respondent argued that "We [the community people] have the right to participate; we are not going to allow foreigners to come here to take advantage [of the natural resources].” In this case, the respondent might have viewed community participation as a empowerment process to counteract the lobbying of some logging companies that usually are in conflict with communities due to extractive concessions (in the Park's buffer zone).

\subsubsection{Communities-Conservationists Relationships}

Literature shows that if there is not mutual trust between communities and conservationists, then local people will decline to participate in conservation management (Adams \& Hulme 2001; Menzies 2007; Thakadu 2005). The PNCAZ experts I interviewed also confirmed the importance of park staff forging good relationships with communities. For example, Fernando Rubio (former Head of CIMA's protection team) mentioned that having a good relationship with people in communities would positively affect communities' perceptions of the protected area; "I believe that good relationships are essential. To be involved in [communities'] soccer games, parties, dancing and music, to share everyday life, that is essential in order for them [community people] to accept new schemes that are rigid, preconceived... No one asked them that there was going to be a Park, and now they have a Park.”

First, conservationists' perceptions of their relationship with communities will be presented and then contrasted with the questionnaire results.

Overall, the perceptions from Park staff were that there was a good relationship with people in communities. As Ruben M. Paitán (Current Head of the PNCAZ) stated: "I think communities are important, and overall we have a good relationship with communities." Miguel Macedo (Head of CIMA's extension section) agreed: “At the community level we have a good relationship in the areas where extension work is done. Sometimes there is a better relationship with Park guards than with the extension agents, sometimes it is the other way around. Basically, I would say that there is a good coordination; people have a good 
relationship." However, some interviewees felt that local people were still dubious of the intentions of the Park staff and hence, relationships between conservationists and communities could be improved. As Andres Cenepo (Park guard and local community member) stated:

I think that we should decentralise INRENA offices, decentralise these offices to places closer to communities, where they would be more integrated with communities. Say, for instance, that the INRENA office is in Tarapoto, or in Lima, then that is too far. Thus, the [local] population will keep on thinking: "well, they [CIMA and INRENA] are managing it; they are doing things as they want." Therefore, there is some suspicion [among community people].

Fernando Rubio (former Head of CIMA's protection team) agreed with the idea of community people being a bit sceptical of staff intentions: "I think that overall, they [community people] have the same type of vision, a bit of distrust. Community people think that those who are promoting and leading the management of the Park might have some hidden interests. These topics always come up."

Results from communities were moderately positive in regards to relationships with Park staff. When I asked about respondents' relationship with the Park staff most of the informants (32 of the 73) chose the neutral option as illustrated in Figure 3.7. However, the second most answered was having a good relationship with the Park staff (29 respondents). 


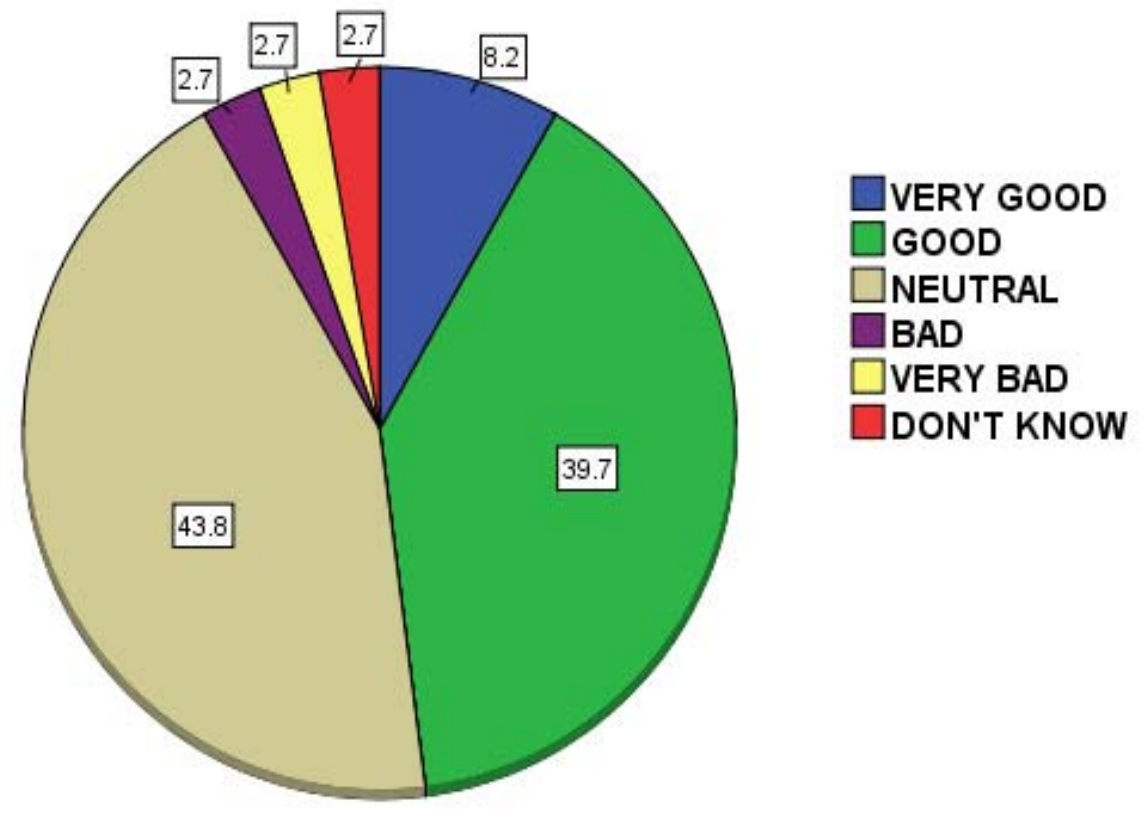

\section{Figure 3.7: Respondents' views of their relationship with the Park staff (in round percents).}

Following this, I asked two questions where I differentiated between CIMA (extension agents) versus INRENA (Park guards) staff. The questions were worded exactly the same but exchanged CIMA staff for Park guards. I focused on whether staff listened to community members. Thus, I used 'listening to local people' as a proxy for the overall relationship. The results for the CIMA question (see Figure 3.8) show a bimodal distribution with roughly half of respondents agreeing or strongly agreeing that CIMA listens to community problems and another roughly $40 \%$ disagreeing or strongly disagreeing. 


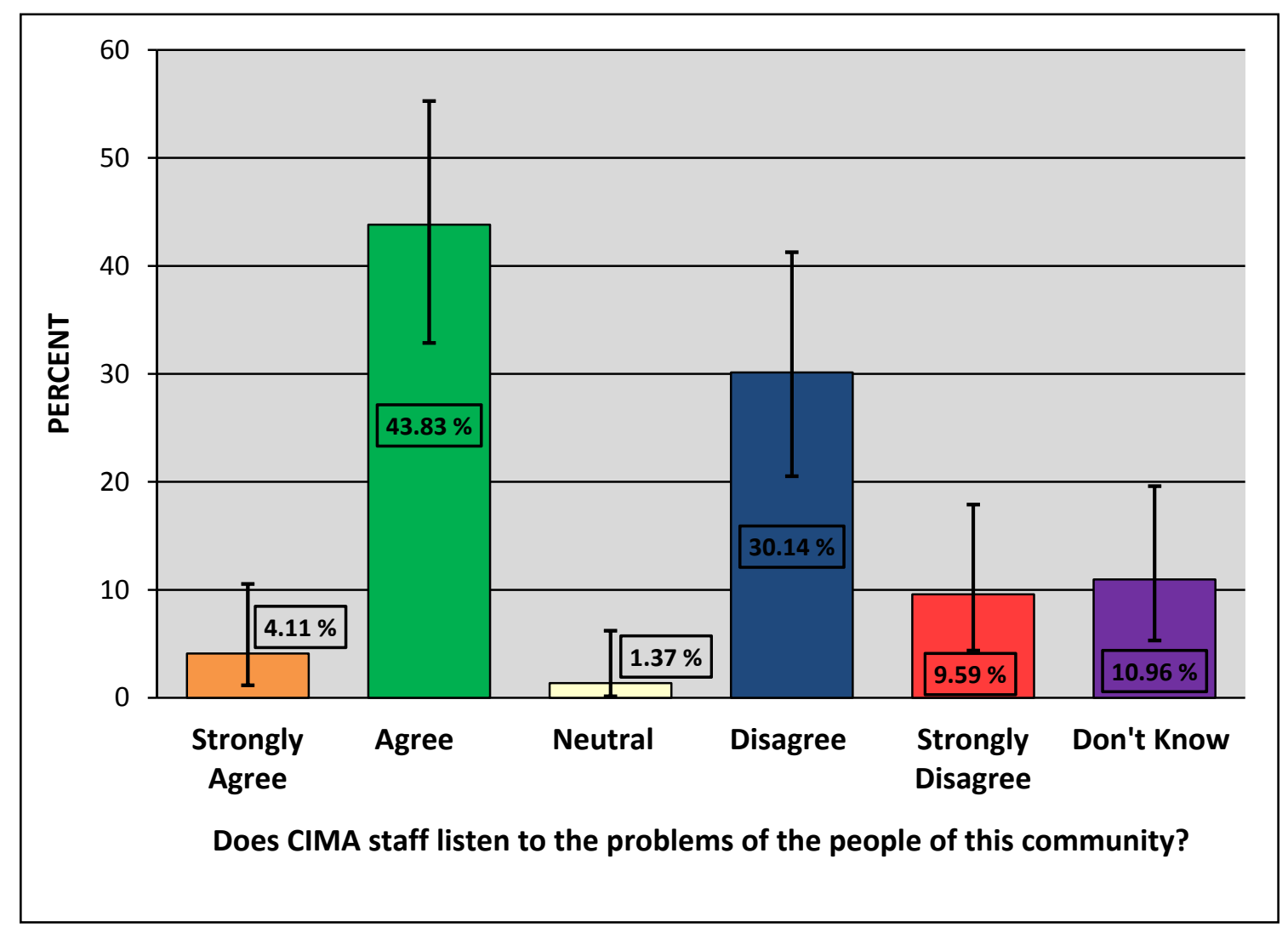

Figure 3.8: Respondents’ perceptions about CIMA staff listening to community people.

The 95\% confidence intervals (displayed as Y error bars in Figure 3.8) overlap for the Agree and Disagree options. Thus, there was no statistically significant difference between the two answers. Also, due to the lack of answers in certain categories, I dropped the 'Neutral' and 'Don't know' answers, and collapsed the scale to test for a significant difference between those in Agreement (including those who Strongly Agreed) versus those in Disagreement (including those who Strongly Disagreed). I found no significant difference between the Agreement and Disagreement options $\left(\chi^{2}(1)=0.562, p>.05\right)$.

On the other hand, as illustrated in Figure 3.9 more respondents agreed that Park guards were taking time to listen to their problems. Furthermore, after collapsing the scale -to test for a significant difference between Agreement versus Disagreement- for the Park guards question, I found that significantly more respondents were in agreement that Park guards listened to their problems $\left(\chi^{2}(1)=23.400, p<.001\right)$. 


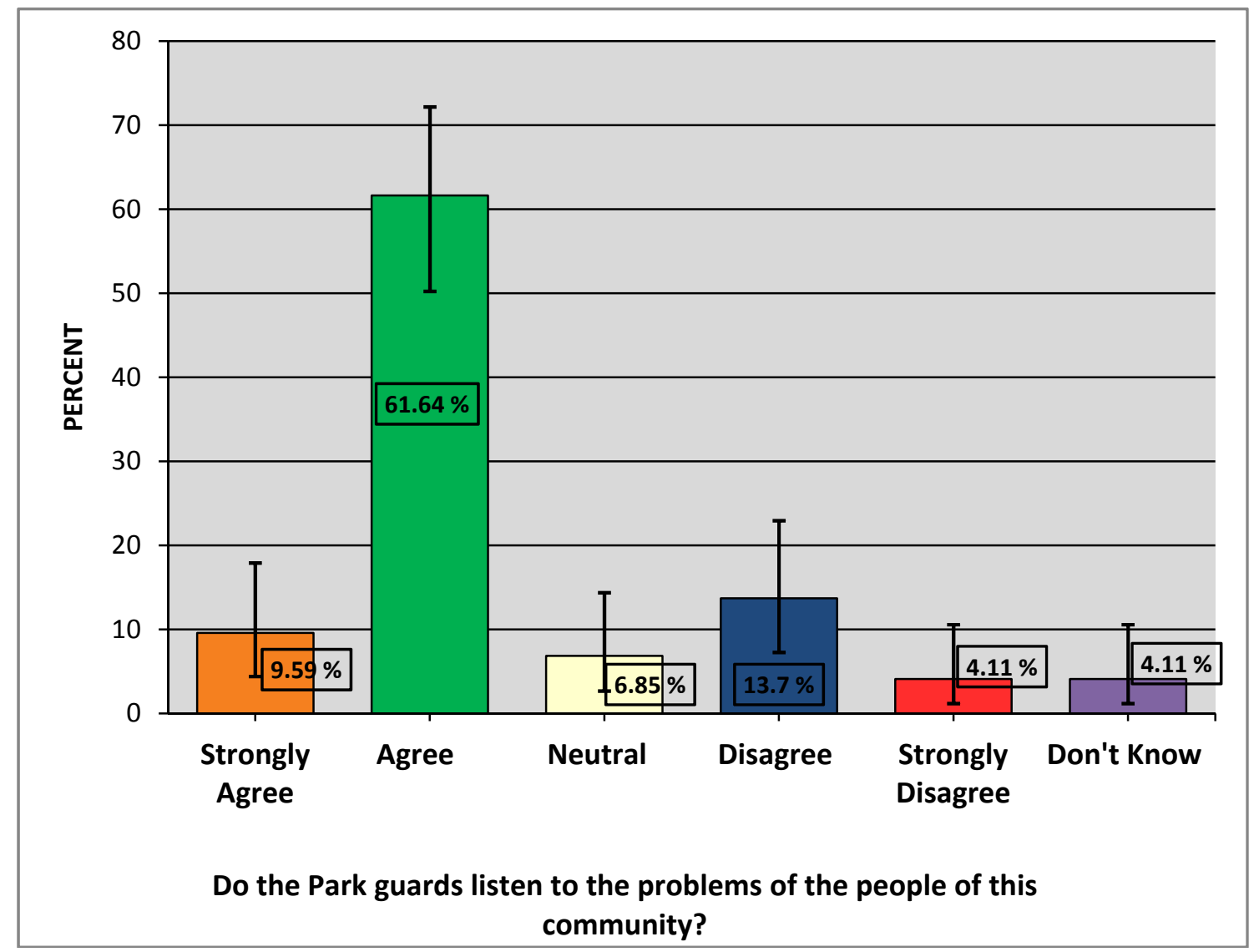

Figure 3.9: Respondents’ perceptions about Park guards listening to community people.

Therefore, results show that overall the communities-conservationists relationship seemed to be good, particularly the relationship between local people and Park guards.

Also, to analyse the correlation between the communities-conservationists relationship and the locally perceived participation I ran Spearman's correlation tests (see Table 3.2). To do so, I examined the correlation between the three questions analysed in this section that relate to the locally perceived relationship between communities and conservationists, and the two questions discussed in section 3.2.3.1 that relate to locally perceived participation. 
Table 3.2: Relationship between locally perceived participation and locally perceived communities-conservationists relationship.

\begin{tabular}{|c|c|c|c|}
\hline $\begin{array}{l}\text { Communities- } \\
\text { Conservationists } \\
\text { Locallionship } \\
\text { Perceived } \\
\text { Participation }\end{array}$ & $\begin{array}{l}\text { Respondent's views of } \\
\text { their relationship with } \\
\text { the Park staff }\end{array}$ & $\begin{array}{l}\text { Perceptions about } \\
\text { CIMA staff listening to } \\
\text { community people }\end{array}$ & $\begin{array}{l}\text { Perceptions about Park } \\
\text { guards listening to } \\
\text { community people }\end{array}$ \\
\hline $\begin{array}{l}\text { Local people are } \\
\text { involved in the } \\
\text { management of the } \\
\text { PNCAZ. }\end{array}$ & $\begin{array}{c}r_{\mathrm{s}}=.283\left(\mathrm{R}^{2}=.080\right) \\
\boldsymbol{p}<.05\end{array}$ & $\begin{array}{c}r_{\mathrm{s}}=.129\left(\mathrm{R}^{2}=.017\right) \\
p>.05\end{array}$ & $\begin{array}{c}r_{\mathrm{s}}=.382\left(\mathrm{R}^{2}=.146\right) \\
\boldsymbol{p}<. \mathbf{0 1}\end{array}$ \\
\hline $\begin{array}{l}\text { Your community is to } \\
\text { some extent responsible } \\
\text { of the Park's } \\
\text { management. }\end{array}$ & $\begin{array}{c}r_{\mathrm{s}}=.123\left(\mathrm{R}^{2}=.015\right) \\
p>.05\end{array}$ & $\begin{array}{c}r_{\mathrm{s}}=.087\left(\mathrm{R}^{2}=.008\right) \\
p>.05\end{array}$ & $\begin{array}{c}r_{\mathrm{s}}=.202\left(\mathrm{R}^{2}=.041\right) \\
p>.05\end{array}$ \\
\hline
\end{tabular}

Table 3.2 shows that there was a significant, yet weak (very low $\mathrm{R}^{2}$ ) positive relationship between the perceived involvement of local people in the Park's management and the locally perceived relationship with Park staff as well as with the Park guards (being the latter correlation more significant than the former). A possible explanation for the not significant correlation between the perceived involvement of local people in the Park's management and the locally perceived relationship with CIMA staff; is that respondents might understand Park staff as essentially being the Park guards. Also, based on these results it appears that communities-conservationists relationship is not correlated with the locally perceived responsibility for the Park's management.

\subsubsection{Ownership of the Park}

Community members expressed a wide range of opinions as to who owned the Park. Some of the categories (see Appendix 6) summarize the idea expressed by the respondents (e.g. the category: $1 / 2$ Peruvian $1 / 2$ Foreign). Data show that most of the community people perceived the Park as Peruvian, although almost the same amount of people did not know who has the ownership of the protected area (see Figure 3.10). 


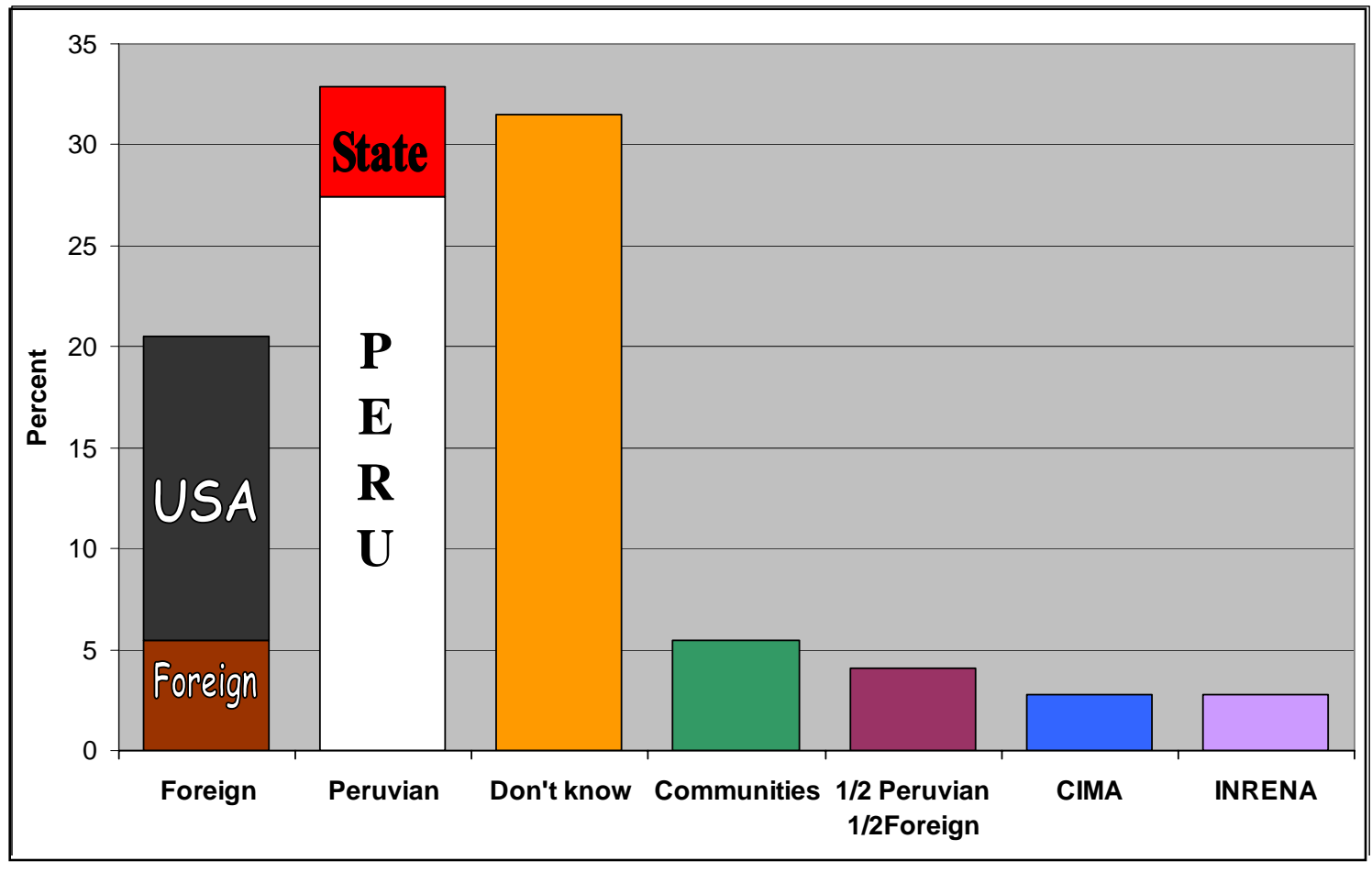

Figure 3.10: Respondent's perception of the PNCAZ's tenure.

The large number of respondents who felt that the Park was owned by foreigners (or the US government) (see Figure 3.10) might be explained by two main factors: The first reason is due to the Park's funding, which comes mainly from USAID and other foreign donors (for instance, the Park guards get paid in US dollars); the second factor is those who have economic interests inside the Park (e.g., logging companies) were opposed to the Park and tried to spread rumours that the National Park had been sold to the USA or other foreigners. For instance, Fernando Rubio (former Head of CIMA's protection team) stated: "I do not know if that will continue, but while I was there we had written in this regard, trying to explain or refuting all these lies - the famous lies that said that the Park belonged to the gringos; that they will expel the people and all of that." Miguel Vásquez (Head of CIMA's extension agents team) agreed:

[The communities] saw it under the point of view that the Park was not entirely

Peruvian... In the entire Park you had that, both in the Northwest and in the East. They usually said: "the Park belongs to the gringos [foreigners] who over time are going to come here". And as they said in some moment: "over time, the gringos will sell us water from the Park in bottles". 
Luis F. Benites (former Head of the Park) pointed out that economic interests of certain people were the underlying reason behind these rumours: "There were always people influenced by the external part, called enablers, or the people that always tried to get wood easily, convincing the communities. And in the communities there are always people that need something, and they do trade-offs or something like that.”

In order to see the correlation between the variables 'ownership' and the two questions about participation analysed in section 3.2.3.1 (see Figures 3.4 and 3.5), I had to run Pearson's chi-square tests. In these cases, I could not test the correlation using the Spearman correlation coefficient because the variable 'ownership' was a categorical variable with more than two categories. However, results violated the chi-square test assumption that all the expected frequencies should be greater than five even after I collapsed the scales.

Notwithstanding, as Figure 3.11 illustrates, it appears that respondents' perceptions of the Park's ownership did not have a major influence in their perceptions about local people involvement in the Park's management. Thus, informants who did not know who owned the PNCAZ and also those who thought that the PNCAZ was foreign owned, still agreed or strongly agreed that local people was involved in the protected area's management (see Figure 3.11 below). 


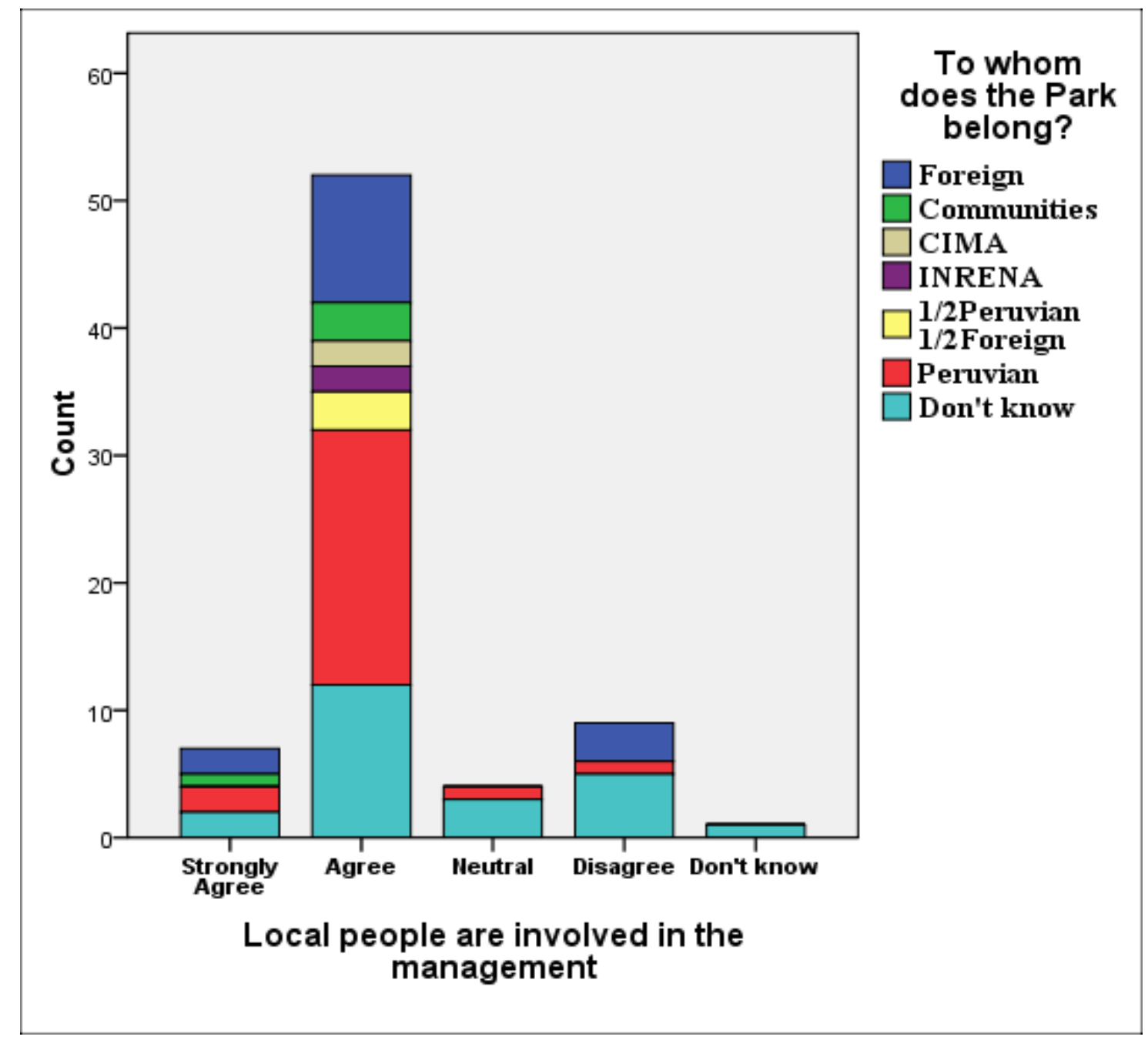

Figure 3.11: Relationship between ownership and perceived local involvement in the PNCAZ's management.

Furthermore, respondents' perceptions of the Park's ownership did not have either a major influence in their perceptions about local people responsibility for the PNCAZ's management (see Figure 3.12 below).

Notwithstanding, it seems that respondents that thought the Park was owned by communities, CIMA, INRENA or that was Peruvian but co-owned by foreigners, were perceiving that both local people were involved and had some responsibility for the PNCAZ's management. Nonetheless, as Figure 3.11 and 3.12 illustrate, there was a considerable variance in the relationship between the three main answers (Peruvian, Don't Know and Foreign) about the Park's ownership and the answers about perceived local involvement and perceived responsibility for the Park's management. 


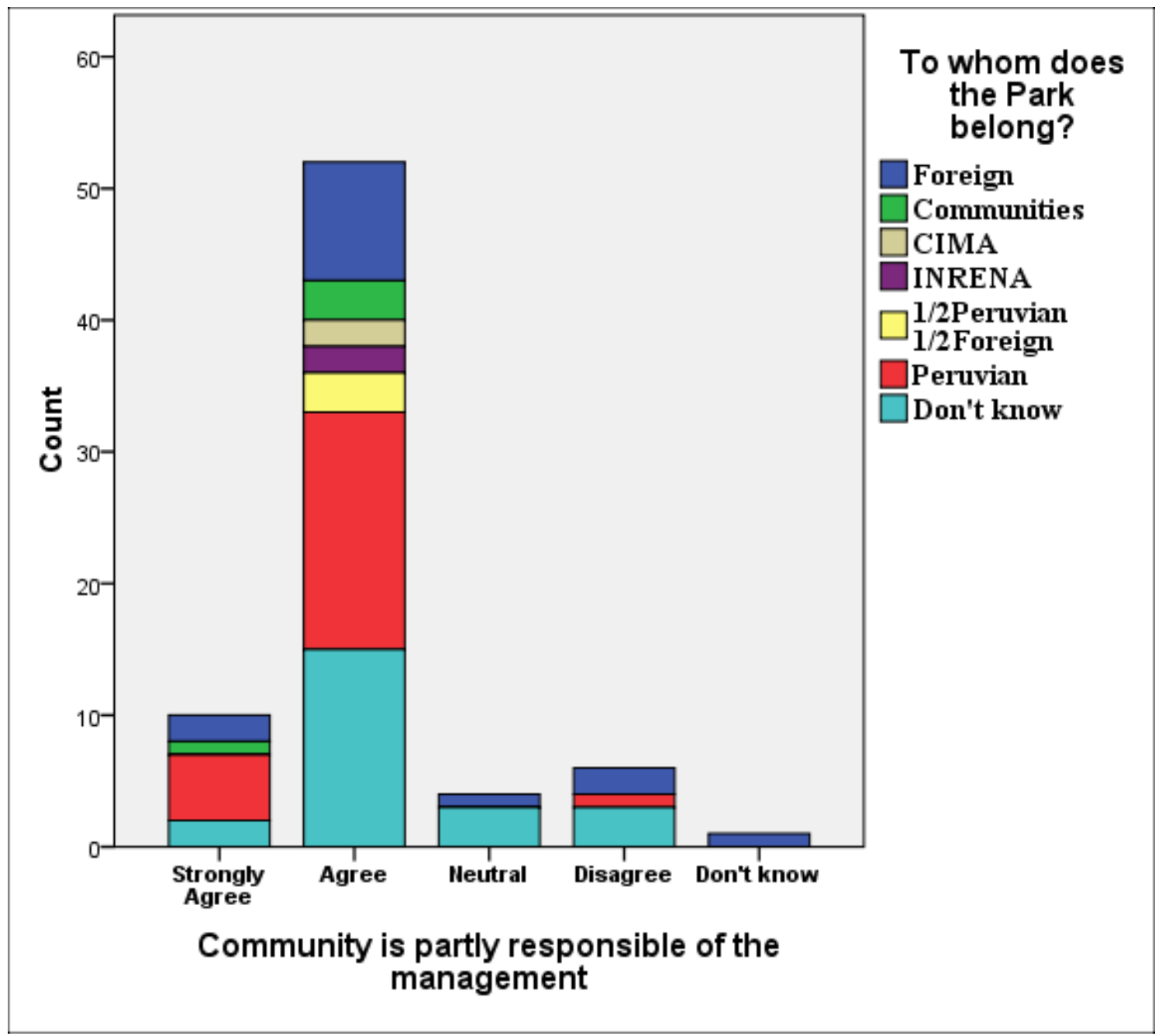

Figure 3.12: Relationship between ownership and perceived community responsibility for the Park's management.

Therefore, it seems that although many respondents did not feel they had a stake in the Park's ownership, the majority perceived the PNCAZ as Peruvian. However, ownership did not appear to be a major barrier to perceived participation. 


\subsubsection{Socio-Demographic Variables}

I also tested the potential effect of two different socio-demographic variables, residence time and education levels, on perceived participation. Thus, as Table 3.3 shows, I look at the correlation of these two socio-demographic variables and: the local attitudes towards participation in the Park's management (see section 3.3.1 and Figure 3.6), the perceived participation questions (see Figures 3.4 and 3.5 in section 3.2.3.1), the communitiesconservationists relationship questions (see section 3.3.2), and the locally perceived benefits and costs questions (see section 3.4.1 below).

Also, data for the socio-demographic variables of 'residence time' and 'level of education' had to be aggregated to allow the use of Spearman's correlation coefficients (see Appendix 7). The five categories for residence time were: people who had been living in the community from 0-5 years; those who had been living in the community between 6-10 years; those who had been there between 11-15 years; those who had been in the community between 16-20 years; and finally those who had been living in the community for 21 years or more. Also, there was one respondent that refused to answer this question reducing the total sample to 72 respondents.

The three categories for education levels were: primary education uncompleted; primary education completed; and secondary education uncompleted. Therefore, it is possible that some data significance was lost when all the different possibilities were aggregated into fewer categories. 
Table 3.3: Spearman correlations coefficients for the socio-demographic variables.

\begin{tabular}{|c|c|c|}
\hline & Residence Time & Levels of Education \\
\hline $\begin{array}{l}\text { Attitudes towards } \\
\text { Conservation }\end{array}$ & $\begin{array}{c}r_{\mathrm{s}}=-.122\left(\mathrm{R}^{2}=.015\right) \\
p>.05, \mathrm{~N}=72\end{array}$ & $\begin{array}{c}r_{\mathrm{s}}=-.009\left(\mathrm{R}^{2}=.000\right) \\
p>.05, \mathrm{~N}=73\end{array}$ \\
\hline $\begin{array}{l}\text { Local people are involved in } \\
\text { the management of the } \\
\text { PNCAZ. }\end{array}$ & $\begin{array}{c}r_{\mathrm{s}}=.040\left(\mathrm{R}^{2}=.002\right) \\
p>.05, \mathrm{~N}=72\end{array}$ & $\begin{array}{c}r_{\mathrm{s}}=.100\left(\mathrm{R}^{2}=.010\right) \\
p>.05, \mathrm{~N}=73\end{array}$ \\
\hline $\begin{array}{l}\text { Your community is to some } \\
\text { extent responsible of the } \\
\text { Park's management }\end{array}$ & $\begin{array}{c}r_{\mathrm{s}}=-.060\left(\mathrm{R}^{2}=.004\right) \\
p>.05, \mathrm{~N}=72\end{array}$ & $\begin{array}{c}r_{\mathrm{s}}=.031\left(\mathrm{R}^{2}=.001\right) \\
p>.05, \mathrm{~N}=73\end{array}$ \\
\hline Relationship with Park staff & $\begin{array}{c}r_{\mathrm{s}}=-.229\left(\mathrm{R}^{2}=.052\right) \\
p>.05, \mathrm{~N}=72\end{array}$ & $\begin{array}{c}r_{\mathrm{s}}=-.093\left(\mathrm{R}^{2}=.009\right) \\
p>.05, \mathrm{~N}=73\end{array}$ \\
\hline $\begin{array}{l}\text { Park guards listen to } \\
\text { community people problems }\end{array}$ & $\begin{array}{c}r_{\mathrm{s}}=-.104\left(\mathrm{R}^{2}=.011\right) \\
p>.05, \mathrm{~N}=72\end{array}$ & $\begin{array}{c}r_{\mathrm{s}}=-.024\left(\mathrm{R}^{2}=.001\right) \\
p>.05, \mathrm{~N}=73\end{array}$ \\
\hline $\begin{array}{l}\text { CIMA staff listen to } \\
\text { community people problems }\end{array}$ & $\begin{array}{c}r_{\mathrm{s}}=.086\left(\mathrm{R}^{2}=.007\right) \\
p>.05, \mathrm{~N}=72\end{array}$ & $\begin{array}{c}r_{\mathrm{s}}=.090\left(\mathrm{R}^{2}=.008\right) \\
p>.05, \mathrm{~N}=73\end{array}$ \\
\hline $\begin{array}{c}\text { Park has more positive than } \\
\text { negative impacts }\end{array}$ & $\begin{array}{c}r_{\mathrm{s}}=-.026\left(\mathrm{R}^{2}=.001\right) \\
p>.05, \mathrm{~N}=72\end{array}$ & $\begin{array}{c}r_{\mathrm{s}}=-.110\left(\mathrm{R}^{2}=.012\right) \\
p>.05, \mathrm{~N}=73\end{array}$ \\
\hline $\begin{array}{c}\text { Perceived Benefits from the } \\
\text { Park }\end{array}$ & $\begin{array}{c}r_{\mathrm{s}}=.000\left(\mathrm{R}^{2}=.000\right) \\
p>.05, \mathrm{~N}=72\end{array}$ & $\begin{array}{c}r_{\mathrm{s}}=-.178\left(\mathrm{R}^{2}=.032\right) \\
p>.05, \mathrm{~N}=73\end{array}$ \\
\hline $\begin{array}{l}\text { Perceived Benefits from the } \\
\text { bush inside the Park }\end{array}$ & $\begin{array}{c}r_{\mathrm{s}}=-.310\left(\mathrm{R}^{2}=.096\right) \\
p<.01, \mathrm{~N}=72\end{array}$ & $\begin{array}{c}r_{\mathrm{s}}=-.224\left(\mathrm{R}^{2}=.050\right) \\
p>.05, \mathrm{~N}=73\end{array}$ \\
\hline Perceived Costs from the Park & $\begin{array}{c}r_{\mathrm{s}}=-.044\left(\mathrm{R}^{2}=.002\right) \\
p>.05, \mathrm{~N}=72\end{array}$ & $\begin{array}{c}r_{\mathrm{s}}=-.090\left(\mathrm{R}^{2}=.008\right) \\
p>.05, \mathrm{~N}=73\end{array}$ \\
\hline
\end{tabular}

As Table 3.3 illustrates, there was only a significant (albeit weak) negative relationship between residence time and the locally perceived benefits from the bush inside the Park. 


\subsection{Relationship between Participation and Perceived Benefits and Costs}

The third objective of my thesis was to examine the relationship between locally perceived levels of participation and locally perceived costs and benefits stemming from the PNCAZ. Thus, the first part of this section shows the results of the questionnaire respondents' perceived benefits and costs from the PNCAZ. This is followed by the conservationists' perceptions regarding local acceptance of the protected area. Finally, the third part of this section looks at the relationship between levels of participation and the perceived benefits and costs.

\subsubsection{Locally Perceived Benefits and Costs}

In question 19 of the questionnaire I asked whether the National Park provided any benefit to the respondent and his/her family. Of the 73 respondents, 35 people disagreed with the possibility that the Park provided any benefit, 22 agreed, six were neutral, six informants strongly disagreed and four respondents strongly agreed (see Figure 3.13).

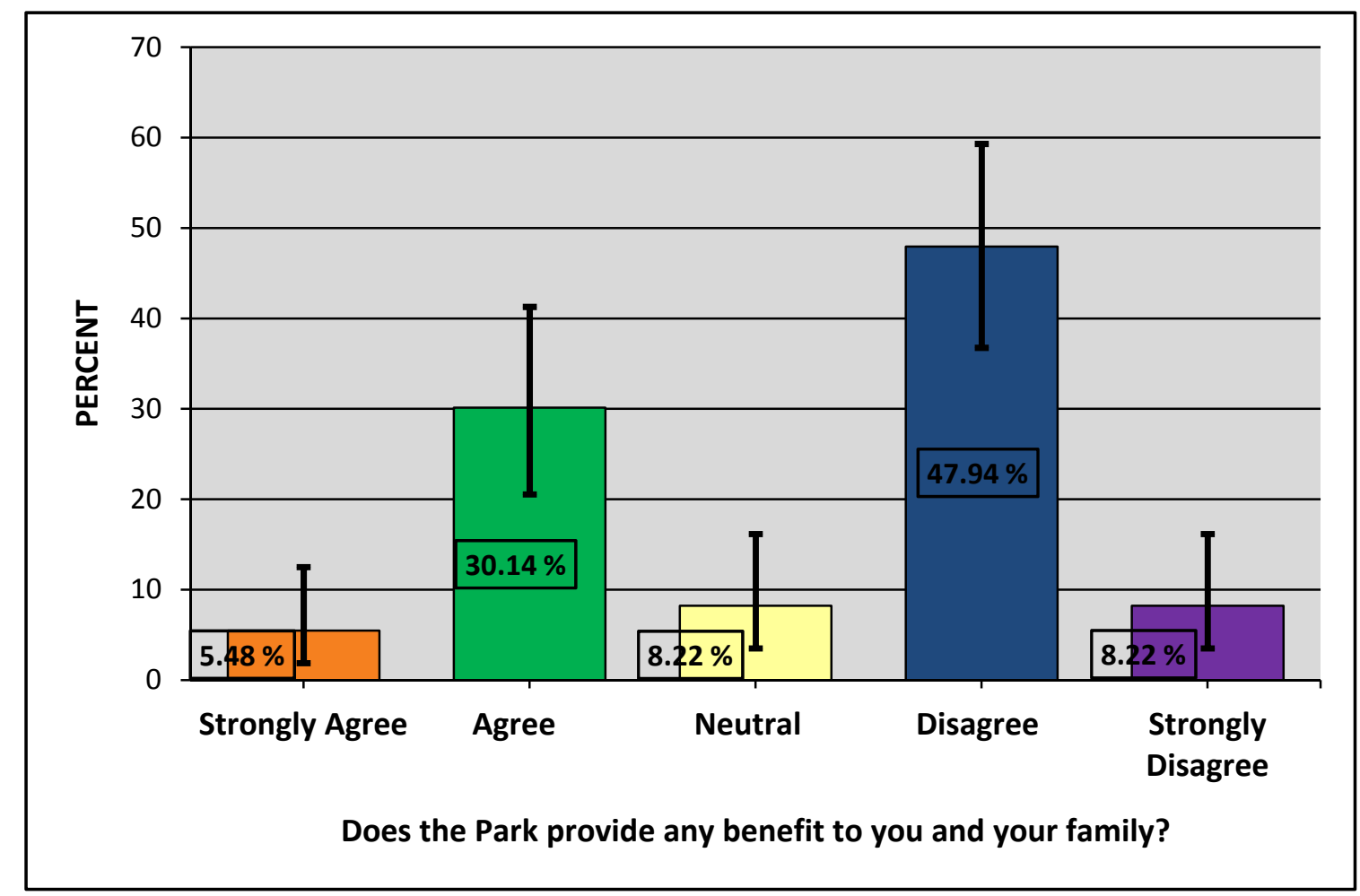

Figure 3.13: Views of the benefits emerging from the Park.

As illustrated in Figure 3.13, the 95\% confidence intervals for the Agree and Disagree options overlap. Thus, differences between the two options were not statistically significant. Also, due to the lack of answers in certain categories, I dropped the 'Neutral' and 'Don't know' answers, and collapsed the scale to test for a significant difference between those in 
Agreement (including those who Strongly Agreed) versus those in Disagreement (including those who Strongly Disagreed). I found no significant difference between the Agreement and Disagreement options $\left(\chi^{2}(1)=3.358, p>.05, \mathrm{~N}=67\right)$.

The 26 respondents that answered that the Park provided some benefit to them and their families were asked to list the benefits. Three main themes arose as a result of this openended question. Twelve people mentioned that the protected area provided ecosystem services by stopping deforestation, maintaining healthy natural resources or 'keeping the rain'. Eight people stated that the Park provided them with some work, or that their community received some kind of support from those managing the Park. One respondent said: "When we need something, the Park [staff] supports us, for example they provide us medicines against insect stings." Finally, six respondents mentioned that the PNCAZ was a source of animals for hunting and fishing. For instance, one informant stated: "We [community people] go fishing and hunting [into the PNCAZ] to eat [not for commercial purposes], with the Park guards' consent."

The next question was specifically asking whether the bush inside the Park provided benefits to the respondents and their families. Contrary to the previous question, this time notably more respondents agreed that the Park was giving them some benefits (see Figure 3.14). Thus, in order to test for a significant difference between those in Agreement (including those who Strongly Agreed) versus those in Disagreement (including those who Strongly Disagreed) I dropped the 'Neutral' and 'Don't know' answers and collapsed the scale. I found that significantly more respondents agreed with the statement that the bush inside the Park provided some benefits $\left(\chi^{2}(1)=7.667, p<.01, \mathrm{~N}=69\right)$. 


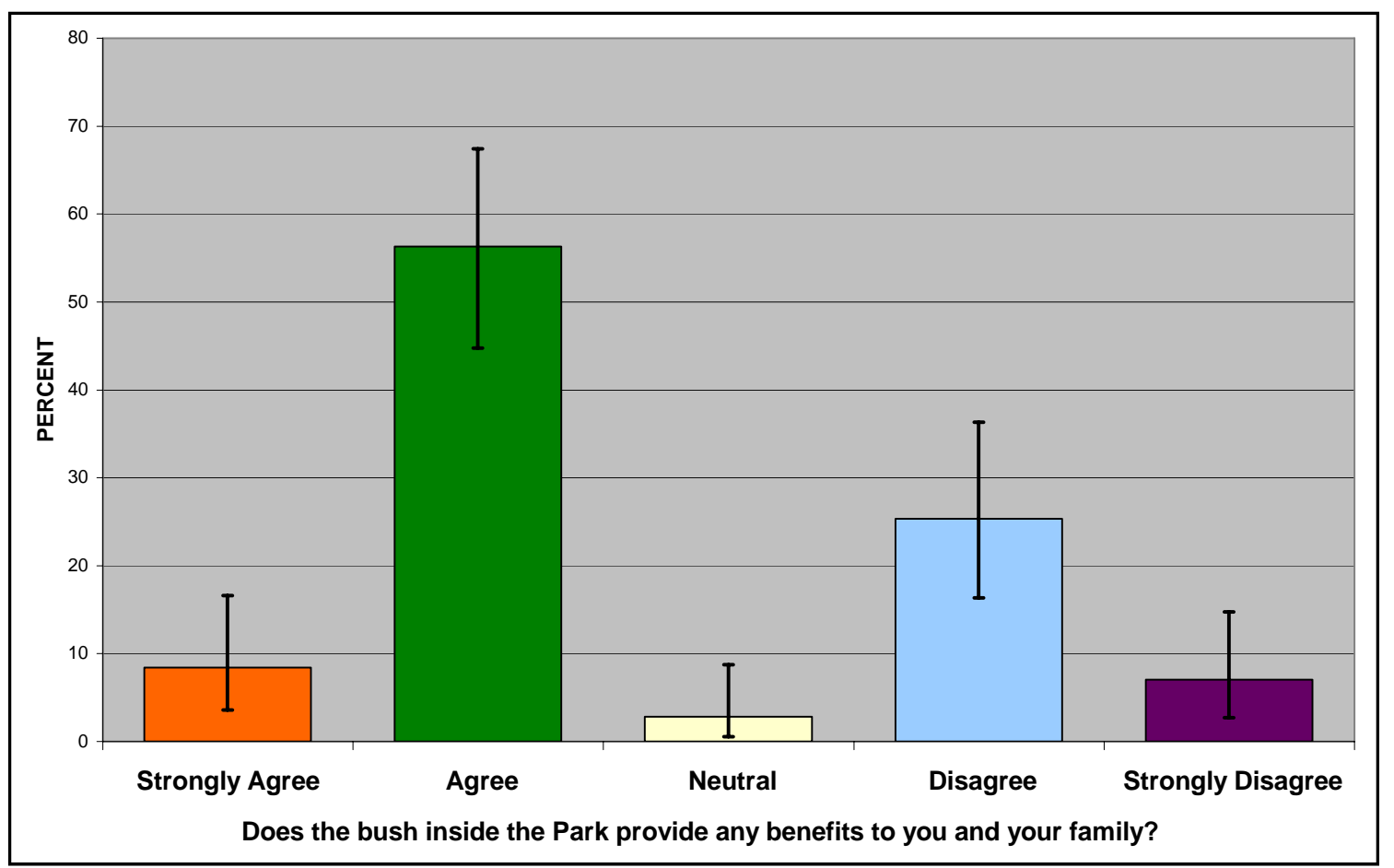

Figure 3.14: Views of the benefits from the bush inside the Park.

Again, to actually identify what the participants perceived as benefits, question 21 was followed by an open-ended question asking for a list of the bush's benefits. In this case four main themes emerged from the 46 answers. Eighteen people mentioned that the bush inside the Park provided animals for hunting. Seventeen respondents cited natural resources (including water) as the benefits from the bush inside the protected area. Nine people referred to ecosystem services such as oxygen and rain. Lastly, two people mentioned medicinal plants as an example of the benefits coming from the bush inside the PNCAZ.

To identify the perceived costs of living close to the National Park I asked if respondents had had any losses or problems because of the Park. As Figure 3.15 shows, remarkably more respondents did not consider the Park to have caused them any losses. 


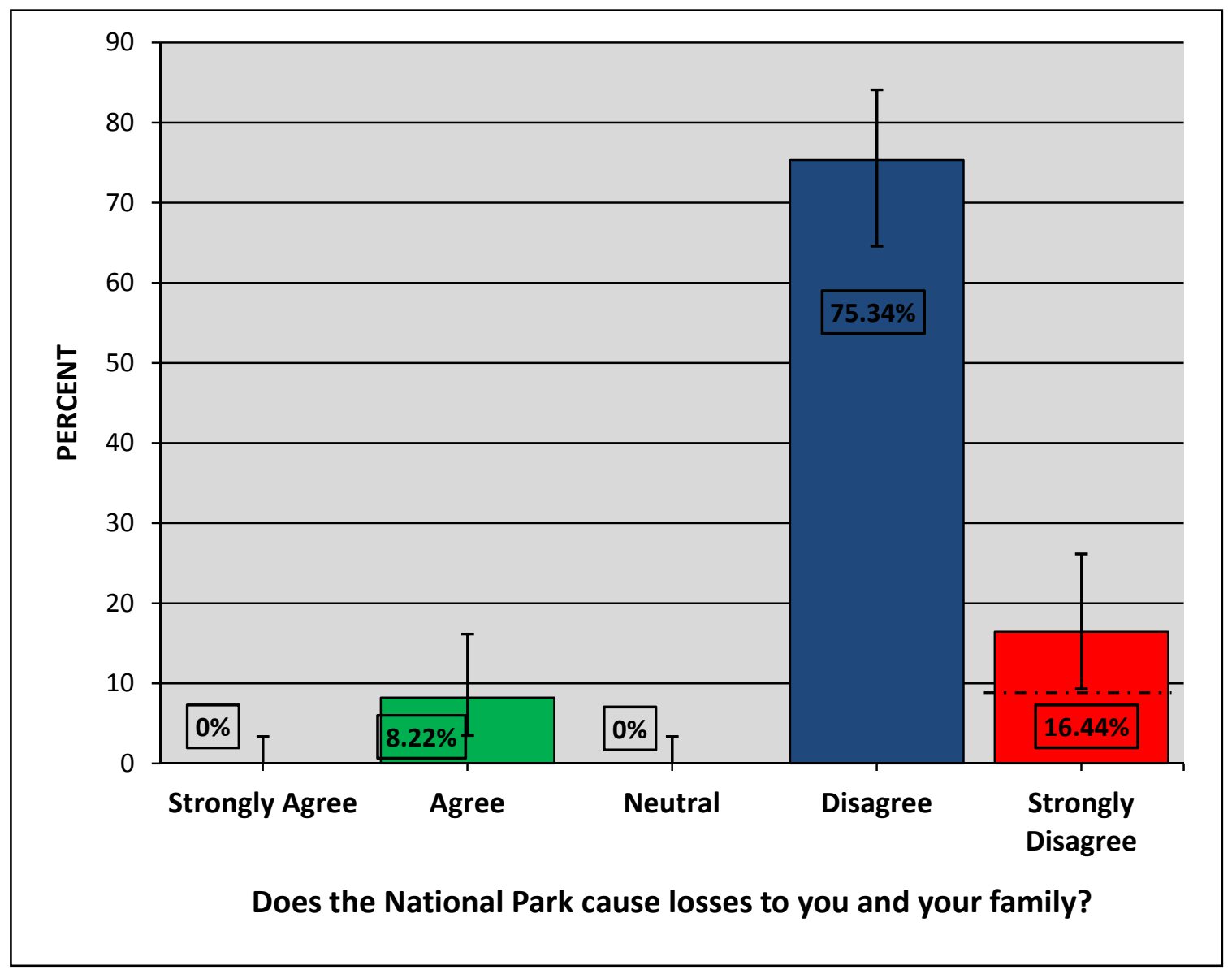

\section{Figure 3.15: Opinions about costs caused by the Park.}

After collapsing the scale (to a two point scale of agree vs. disagree), I found that significantly more respondents disagreed with the statement that the Park caused losses $\left(\chi^{2}\right.$ $(1)=50.973, p<.001, N=73)$. Only six people felt that the Park had caused them losses. Three of these people explained that they had lost land they had inside the Park. One informant argued that people were not allowed to enter the Park. The third respondent mentioned that the losses caused by the Park related to Park guards not controlling the entrance of illegal loggers into the Park.

Finally, I asked whether the Park had more positive than negative impacts on the respondents and their families. Of the 73 respondents, $67.1 \%$ felt that the Park was affecting their lives in a more positive manner, $24.7 \%$ of the respondents felt that the protected area affected them negatively, $4.1 \%$ of the people said that they did not know, and another $4.1 \%$ felt that the Park had neither positive nor negative impacts on their lives (see Figure 3.16). 


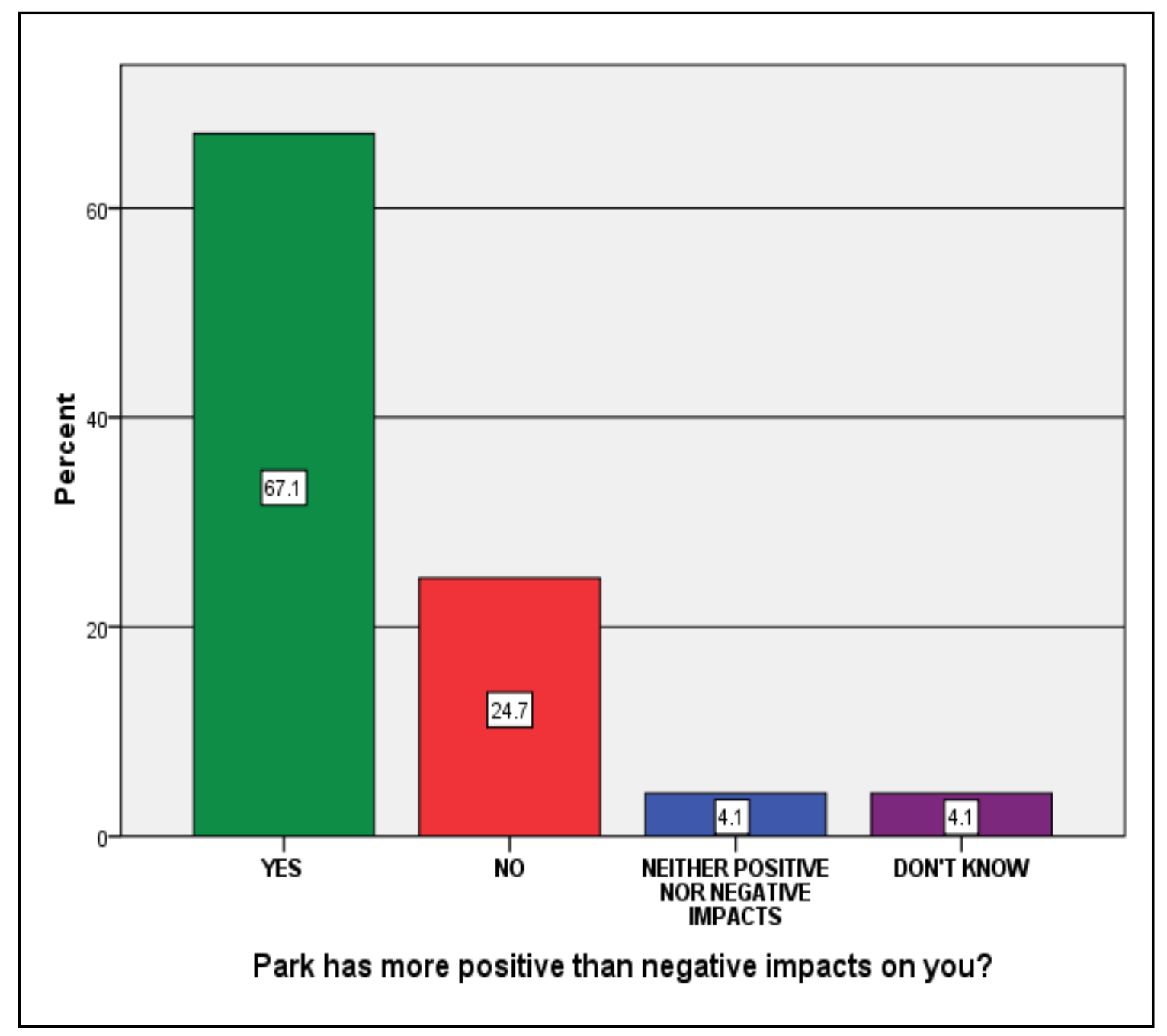

Figure 3.16: Opinions about the Park having more positive impacts.

However, due to the positive wording of the question I cannot disregard its bias effect on the participants' answers. Nevertheless, it seems that the trend is that the majority of the people from these communities did not perceive the PNCAZ as causing them losses, and that many were conscious of the benefits that stemmed from the National Park.

The literature suggests that community participation will influence locally perceived benefits and costs (Menzies 2007; Spiteri \& Nepal 2006; Thakadu 2005). In order to test this assumption, I looked at the relationship between the two questions on perceived participation (see Figures 3.4 and 3.5 in section 3.2.3.1) and: the three questions on perceived benefits, and the question on perceived costs. The results of the Spearman correlation test are outlined in Table 3.4. 
Table 3.4: Correlation between perceived participation and the locally perceived benefits and costs.

\begin{tabular}{|c|c|c|c|c|}
\hline & $\begin{array}{c}\text { The Park } \\
\text { provides } \\
\text { benefits to you? }\end{array}$ & $\begin{array}{c}\text { The bush inside } \\
\text { the Park } \\
\text { provides } \\
\text { benefits to you? }\end{array}$ & $\begin{array}{c}\text { The Park caused } \\
\text { losses to you? }\end{array}$ & $\begin{array}{l}\text { Park has more } \\
\text { positive than } \\
\text { negative impacts } \\
\text { on you? }\end{array}$ \\
\hline $\begin{array}{c}\text { Local people } \\
\text { are involved in } \\
\text { the } \\
\text { management } \\
\text { of the PNCAZ. }\end{array}$ & $\begin{array}{c}r_{\mathrm{s}}=.246 \\
\left(\mathrm{R}^{2}=.061\right) \\
p<.05 \\
\mathrm{~N}=73\end{array}$ & $\begin{array}{c}r_{\mathrm{s}}=-.063 \\
\left(\mathrm{R}^{2}=.004\right) \\
p>.05 \\
\mathrm{~N}=73\end{array}$ & $\begin{array}{c}r_{\mathrm{s}}=-.087 \\
\left(\mathrm{R}^{2}=.008\right) \\
p>.05 \\
\mathrm{~N}=73\end{array}$ & $\begin{array}{c}r_{\mathrm{s}}=.197 \\
\left(\mathrm{R}^{2}=.039\right) \\
p>.05 \\
\mathrm{~N}=73\end{array}$ \\
\hline $\begin{array}{l}\text { Your } \\
\text { community is } \\
\text { to some extent } \\
\text { responsible of } \\
\text { the Park's } \\
\text { management. }\end{array}$ & $\begin{array}{c}r_{\mathrm{s}}=.239 \\
\left(\mathrm{R}^{2}=.057\right) \\
p<.05 \\
\mathrm{~N}=73\end{array}$ & $\begin{array}{c}r_{\mathrm{s}}=.178 \\
\left(\mathrm{R}^{2}=.032\right) \\
p>.05 \\
\mathrm{~N}=73\end{array}$ & $\begin{array}{c}r_{\mathrm{s}}=-.155 \\
\left(\mathrm{R}^{2}=.024\right) \\
p>.05 \\
\mathrm{~N}=73\end{array}$ & $\begin{array}{c}r_{\mathrm{s}}=.205 \\
\left(\mathrm{R}^{2}=.042\right) \\
p>.05 \\
\mathrm{~N}=73\end{array}$ \\
\hline
\end{tabular}

As illustrated in Table 3.4, the correlation was significant (albeit weak) between the locally perceived benefits from the Park and the two questions on perceived participation. However, these results do not clarify the causality direction, so it might be the case that an increase in perceived participation will translate in an increase in the perceived benefits from the Park, or could also happen that an increase in the perceived benefits from the Park translates into an increase in the perceived participation. 


\subsubsection{Conservationists' Perceptions of Communities’ Park Acceptance and Perceived Benefits}

Community members' perceptions regarding the general net benefits of the Park correspond with interviewees' opinions about communities accepting the Park and being conscious of the Park's benefits. For instance, Dave Pogois (PNCAZ Programme Director) mentioned that communities accept the Park and he pointed out that in other protected areas where that was not the case, conflicts were taking place.

There is a sense of legitimacy to the Park. Communities have a clear concept of the Park, it is not ideal, there is still a way to go, but there is a difference with other [protected] areas... If you compare it with other protected areas, then the situation is immensely different. For instance, there are people [in communities near other protected areas] that tell you, even Management Committees that tell you that they want to invade the Park because it is for the population.

- Dave Pogois (PNCAZ Programme Director).

In line with this, Alaka Wali (Field Museums' Director of the CCUC) also pointed out that in the PNCAZ communities were not rejecting the Park and hence you could not see major conflicts: "I think the evidence for that is the fact that you do not see a lot of encroachment, you do not see a lot of illegal activities; you do not see them rejecting the CIMA team in their communities. From what people told me there has been really good participation in the landuse planning, which is hard work, and so people have been doing that."

Andres Cenepo (Park guard and local community member) agreed with the fact that communities perceived the Park's benefits to some extent: "I cannot say that there is a 100 percent acceptance [...] But around 80 percent of the population knows what the benefits are, what the use norms inside the protected area are, what they have to do and what they should not do.” Also, Lily Rodríguez, the former CIMA president, pointed out that people have always had a positive perception of the Park: "There was never a rejection of the Park because these are areas that people did not use much. That is why I think there has never been a rejection of the Park."

However, Adler Shapiama (Park guard) indicated that communities might have changed their perceptions about the Park over time: "At the beginning there was a rejection of the 
Park, but nowadays mainly because of the scarcity of water resources, there is a change in opinion. They [the communities] see the Park as an ally for environmental protection. Also, they see it as an institution that could help them in some administrative tasks.” Miguel Macedo (Head of CIMA's extension section) also disagreed with Rodríguez about community people accepting the Park from the beginning:

The people now have more knowledge [about the Park]. At the beginning it was more difficult to get communities to accept the Park. But now, there is more compromise, even though it might be doing small things like contracting them to work, for instance. Then you manage to get people slowly identifying with the Park.

Therefore, the perceptions of both CIMA's staff and INRENA's officials appeared to be that communities did not seem to be rejecting the PNCAZ. Many interviewees also mentioned that although community people might not have been completely committed to the National Park, the majority of the communities saw value in the Park. Thus, it appears that conservationists associated the low levels of conflicts in and around the PNCAZ to the fact community people seemed to accept the Park. In turn, this local acceptance of the Park might have been caused by communities having an overall perception of net benefits (benefits outweigh the costs) coming from the Park.

\subsection{Variables affecting Participation}

These findings illustrate that multiple factors are likely to affect (perceived) participation, with any given variable only able to explain a part of the variance in the locally perceived participation. Consequently, all the correlation coefficients for the variables measured in this study were very low when using bivariate analyses. Therefore, in order to clarify how the different variables measured in this thesis might be combining to influence participation (see Figure 3.17) two multiple regression analysis were conducted. 


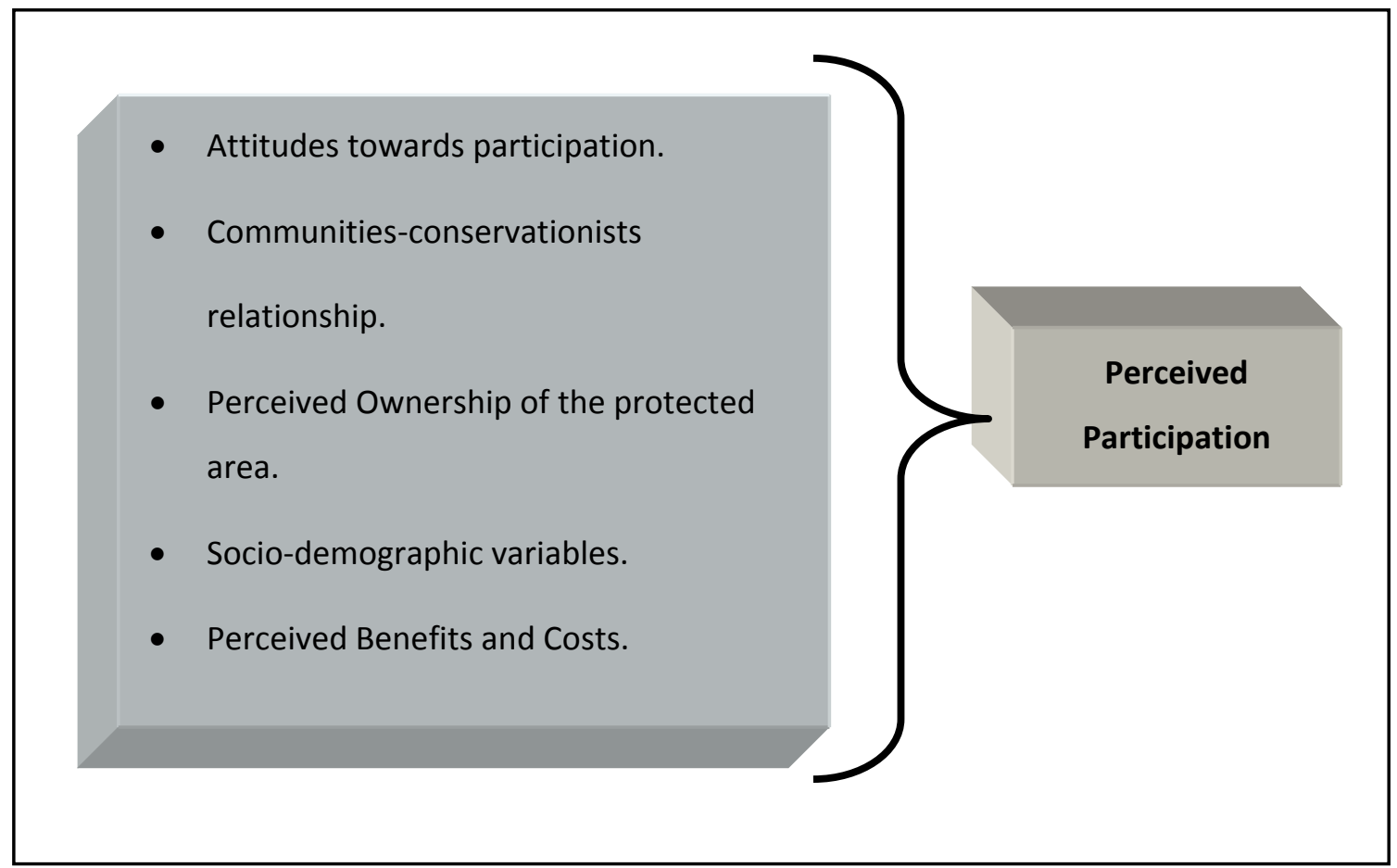

Figure 3.17: Potential variables affecting Perceived Participation in the PNCAZ.

The outcome or dependent variables of the analysis were the perceived participation questions (one related to the perceived local involvement in the Park's management the perceived local involvement in the Park's management, and the other question related to the perceived responsibility for the Park's management). However, these variables were not a true five point scale because the 'Strongly Disagree' option had a frequency of zero (see Figures 3.4 and 3.5). Thus, it could be argued that these were not continuous variables. Therefore, I collapsed both questions in order to have dichotomous variables. In doing so, I collapsed the options 'Strongly Agree' and 'Agree' into the category of 'Perceived Local Involvement' for the question about locally perceived involvement in the management of the PNCAZ; and into the category 'Perceived Responsibility' for the question about locally perceived responsibility for the management of the PNCAZ. Those who 'Disagreed' where now categorised as 'Not Perceived Local Involvement' and 'Not Perceived Responsibility' respectively. However, it reduced the sample to an overall of 68 people, as those people (six people in both cases) that fall in the category of 'Neutral' or 'Don't know' were discarded. Therefore, the two locally perceived participation variables had the following frequencies:

- Perceived Local Involvement: 59 respondents.

- Not Perceived Local Involvement: 9 respondents. 
> Perceived Responsibility: 62 respondents.

Not Perceived Responsibility: 6 respondents.

To determine which variables could be potential predictors (independent variables) of participation, I ran correlation tests (Spearman or chi-square tests) for each of the potential variables affecting participation (see Figure 3.17) with the two perceived participation variables. Table 3.5 outlines the variables that had a significant correlation with the two 'perceived participation' variables.

Table 3.5: Spearman's correlation coefficients between the perceived participation variables and its potential predictors.

\begin{tabular}{|c|c|c|}
\hline & $\begin{array}{c}\text { Perceived local involvement } \\
\text { versus } \\
\text { Not Perceived Local } \\
\text { Involvement }\end{array}$ & $\begin{array}{c}\text { Perceived responsibility } \\
\text { versus } \\
\text { Not Perceived } \\
\text { Responsibility }\end{array}$ \\
\hline $\begin{array}{c}\text { Attitudes towards } \\
\text { participation }\end{array}$ & Not significant \\
\hline $\begin{array}{c}\text { How is your } \\
\text { relationship with the }\end{array}$ & $r_{\mathrm{s}}=.284\left(\mathrm{R}^{2}=.081\right)$ & $r_{\mathrm{s}}=.438\left(\mathrm{R}^{2}=.192\right)$ \\
Park's staff? & $p<.05 ; \mathrm{N}=68$ & $\begin{array}{c}\text { Not significant } \\
\text { Does the Park provide } \\
\text { any benefit to you and } \\
\text { your family? }\end{array}$
\end{tabular}

Therefore the questions (independent variables) included in the regression analysis were:

$\checkmark$ Attitudes towards conservation (Do you want your community to be more involved in the Park's management?).

$\checkmark$ Communities-conservationists relationship (How is your relationship with the Park's staff?; Does CIMA staff listen to the problems of the people of this 
community?; Do the Park guards listen to the problems of the people of this community?).

$\checkmark$ Perceived benefits and costs (Does the Park provide any benefit to you and your family?; Does the bush inside the Park provide any benefit to you and your family?; Does the National Park cause losses to you and your family?).

Lastly, given that the outcomes or dependent variables were categorical dichotomies, I ran two (stepwise) logistic regressions with seven independent variables.

For the case of the perceived local involvement in the Park's management, the residual chisquare statistic was $\chi^{2}(7)=14.532, p<.05, \mathrm{~N}=68$. Because the probability for the residual chi-square of the model (significant at .042) was just smaller than .05, it meant that none of the variables excluded from the model could make a significant contribution to the predictive power of the model (all the predictors had $p>.05$ ). As a result, none of the independent variables were added to the model, and the logistic regression terminated at this stage. Therefore, none of the seven potential variables analysed were in fact notably affecting the perceived local involvement in the Park's management.

A possible explanation for this result in the logistic regression analysis is that there was not a lot of variance in the answers obtained about the perceived local involvement in the Park's management. Thus, there was not much variance in the perceived local involvement in the Park's management that could be explained for any given variable.

The results of the regression analysis for the 'perceived responsibility for the Park's management' are presented in Table 3.6 (see below). In this case, three of the seven independent variables were affecting the 'perceived responsibility for the Park's management'. 
Table 3.6: Outline of the results from the logistic regression analysis for 'Perceived responsibility for the Park's management'.

95\% Confidence Intervals for $\exp b$

\begin{tabular}{|c|c|c|c|c|}
\hline & $B(S E)$ & Lower & $\exp b$ & Upper \\
\hline \multicolumn{5}{|l|}{ Included } \\
\hline Constant. & $-5.185(3.809)$ & & & \\
\hline Attitudes towards conservation & $7.790(6.156)$ & 0.014 & 2415.846 & $4.194 \times 10^{8}$ \\
\hline $\begin{array}{c}\text { Does the Park provide } \\
\text { any benefit to you } \\
\text { and your family? }\end{array}$ & $2.386 *(1.045)$ & 1.402 & 10.868 & 84.267 \\
\hline $\begin{array}{l}\text { Does the National Park cause } \\
\text { losses to you and your family? }\end{array}$ & $\begin{array}{c}-1.826^{*} \\
(0.908)\end{array}$ & 0.027 & 0.161 & 0.955 \\
\hline
\end{tabular}

Note $R^{2}=.476$ (Hosmer \& Lemeshow), .247 (Cox \& Snell), .550 (Nagelkerke). N= 68 . Model $\chi^{2}(3)=19.309, p<.001 . * p<.05$.

As illustrated in Table 3.6, two of the three independent variables were in fact significantly predicting whether local people will feel responsible for the Park's management or not. In the case of the 'perceived benefits from the Park', the 'exp b' was greater than one, which indicated that as the predictor (i.e. the perceived benefits from the Park) increased, the odds of the outcome occurring (i.e. perceived responsibility for the management) increased. However, the interval between the lower and the upper confidence intervals was quite wide. Confident intervals represent the range of values within which we think the population value falls (Field 2005). Thus, wide confident interval values indicated that the estimates (of the perceived responsibility) produced by this variable (the perceived benefits from the Park) would not be too representative of the true population values. On the other hand, the ' $\exp b$ ' for the 'perceived costs of the Park' was less than one (with a relatively tight confidence interval). Thus, it indicated that as the 'perceived costs of the Park' increased the 'perceived responsibility for the Park's management' decreased. The 'attitudes towards conservation' was also (positively) affecting local people's perception about their responsibility for the Park's management.

Lastly, values of the different $R^{2}$ ranged from .247 to .550 . This meant that among $24.7 \%$ to $55 \%$ of the variation in the outcome variable (the perceived responsibility for the 
management) was accounted for by the final model produced in the logistic regression analysis. Thus, $R^{2}$ values seemed to indicate that the predictors or independent variables moderately predicted the outcome or dependent variable. Furthermore, the chi-square value of the model was in fact quite significant $(p<.001)$, which indicated that the model was a significant fit of the data. 


\section{Chapter four: Discussion and Conclusions}

\subsection{Introduction}

In this chapter the findings of this case study will be discussed in the context of the thesis objectives and research questions. This chapter will conclude with a discussion of the implications of the results for the PNCAZ management and more generally, for the conservation management field.

\subsection{Estimating Levels of Participation across PNCAZ’s Management Stages}

The first objective of this thesis was to examine the levels of local participation at different stages of the Park's management. Estimates of the participatory levels allow for an evaluation of the PNCAZ's management that might contribute to the improvement of this management model.

Participation in conservation management is not one thing, but rather an evolving process of empowerment (Adams \& Hulme 2001; Slocum et al. 1995) that involves different levels of participation (Kumar 2002; da Silva 2004) across the participation continuum (see Figure 1.1). Literature in conservation management mentions that participation can differ from one conservation project to another, but this thesis is the first study which explicitly examines how participatory levels might also vary across management stages.

Results from this case study showed that levels of participation did indeed vary across different stages of the PNCAZ's management (see Table 4.1). During the Park's inception, levels of participation were very low, but community participation increased notably in the following management stage (see Figure 4.1). The participatory methodology applied with the MUF (Mapping of Social Assets and Resource Use) allowed for the increase of communities' participation in the management of the Park. On the other hand, the current management stage of the PNCAZ seemed to be less participatory than the previous period (see Table 4.1 and Figure 4.1). 
Table 4.1: Levels of participation at different management stages.

\begin{tabular}{|c|c|c|c|}
\hline $\begin{array}{l}\text { Management } \\
\text { Stage }\end{array}$ & $\begin{array}{l}\text { Evidence of Levels } \\
\text { of Participation }\end{array}$ & $\begin{array}{l}\text { Barriers to } \\
\text { Participation }\end{array}$ & $\begin{array}{l}\text { Level of } \\
\text { Participation } \\
\text { achieved }\end{array}$ \\
\hline $\begin{array}{l}\text { PNCAZ } \\
\text { establishment }\end{array}$ & $\begin{array}{l}\text { Communities' } \\
\text { unawareness of } \\
\text { the establishment } \\
\text { process. }\end{array}$ & $\begin{array}{l}\text { - Conservationists' } \\
\text { agenda. } \\
\text { - Political process } \\
\text { required. }\end{array}$ & $\begin{array}{l}\text { Instructive } \\
\text { (Government } \\
\text { sole decision- } \\
\text { making) }\end{array}$ \\
\hline $\begin{array}{l}\text { First six years } \\
\text { of the Park's } \\
\text { management } \\
(2002-2008)\end{array}$ & $\begin{array}{l}>\text { Community } \\
\text { perceived } \\
\text { participation in } \\
\text { Park's decisions. } \\
>\text { 2003 MUF: } \\
\text { highly } \\
\text { participatory } \\
\text { process. } \\
>\text { Management } \\
\text { Committee } \\
\text { creation. } \\
>\text { Conservationists' } \\
\text { criticism of } \\
\text { participatory } \\
\text { levels achieved. }\end{array}$ & $\begin{array}{l}\text { - Acuerdos Azules not } \\
\text { properly } \\
\text { implemented. } \\
\text { - Management } \\
\text { Committee not } \\
\text { appropriately } \\
\text { working. }\end{array}$ & $\begin{array}{l}\text { Consultative/ } \\
\text { Co-operative } \\
\text { (Low/medium } \\
\text { levels of } \\
\text { participation). }\end{array}$ \\
\hline $\begin{array}{l}\text { Current } \\
\text { management } \\
\text { stage (2008- } \\
\text { present) }\end{array}$ & $\begin{array}{l}\text { Local people } \\
\text { thought they } \\
\text { were } \\
\text { participating } \\
\text { though they } \\
\text { would like to } \\
\text { participate more. }\end{array}$ & $\begin{array}{l}\text { - Dysfunctional } \\
\text { Management } \\
\text { Committee. } \\
\text { - } 2008 \text { MUF: less } \\
\text { participatory version. }\end{array}$ & $\begin{array}{l}\text { Consultative } \\
\text { (Low levels of } \\
\text { participation). }\end{array}$ \\
\hline
\end{tabular}

As illustrated in Table 4.1 the levels of participation varied with each management stage. Accordingly, the three management periods in which the PNCAZ management has been divided in this study vary across the participation continuum. Based on the results obtained, Figure 4.1 aims to situate these PNCAZ's management stages into the participatory spectrum. 


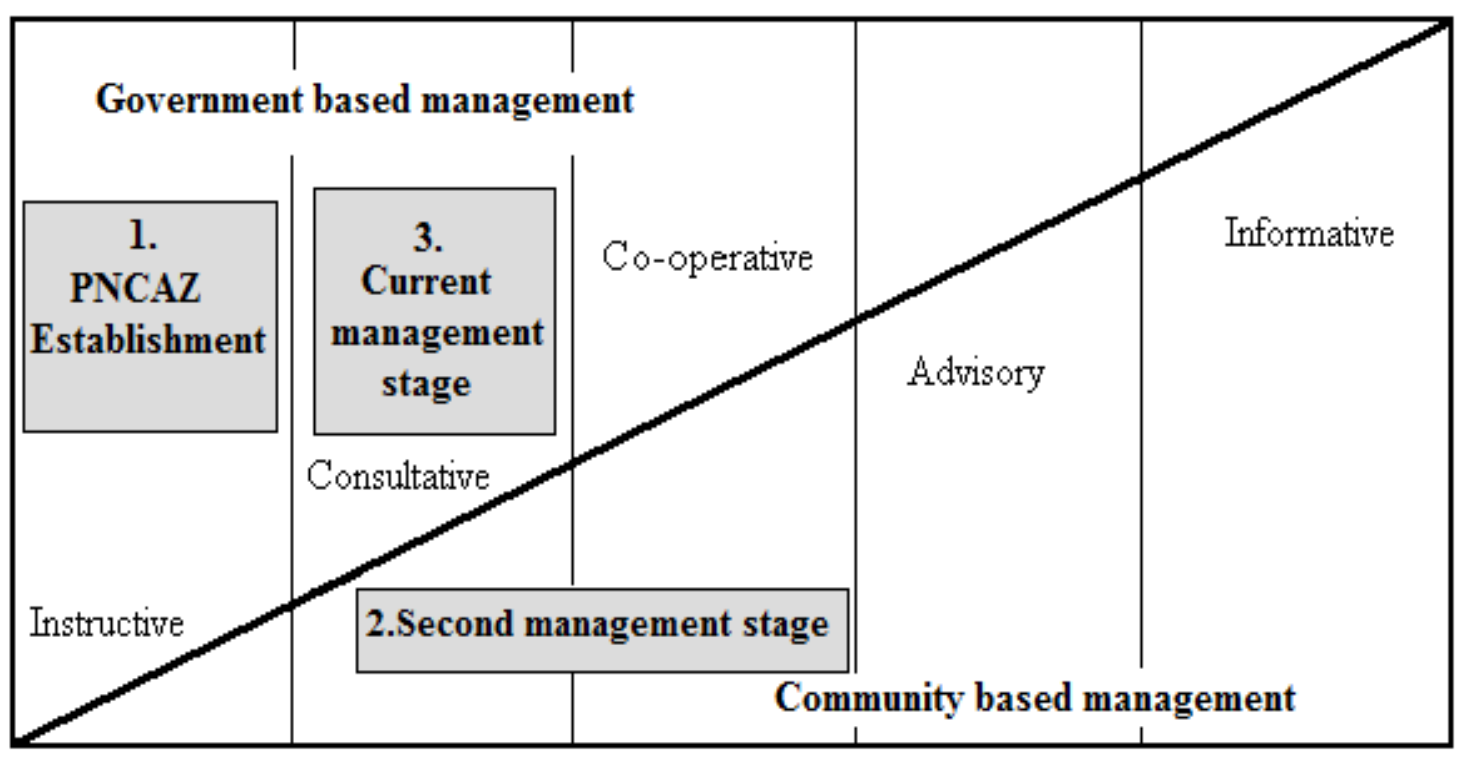

Figure 4.1: PNCAZ management stages in the participation continuum.

Figure 4.1 shows that the three PNCAZ's management stages changed across the participatory continuum, from being an instructive process at the Park's inception, to a more co-operative management practice during the first six years of the Park's management, and finally to a more consultative approach in the current management stage. In the remainder of this section the reasons as to why participation varied across the management stages will be discussed.

Participatory processes are not cheap, and usually require long-term approaches (Kellert et al. 2000; Kumar 2002; Menzies 2007; Sayer \& Wells 2004; Spiteri \& Nepal 2006). However, the Park's establishment was done in a very short time period, with few human and economic resources available to cover a large area of land. The fact that most of the local people surveyed did not know how communities were involved in the Park's creation reinforced interviewees' opinions about the low level of participation in this process. Literature differentiates between participation as a mean or an end in itself (Chapin 2004; Kumar 2002; Mayo \& Craig 2004). Peruvian laws require a consultation process before a protected area is created. Based on my results, it seems that the participatory process during the Park's establishment was viewed as a required means to achieve the PNCAZ creation and not a goal or end in itself.

Also, the often long and expensive participatory processes (Kellert et al. 2000; Kumar 2002; Menzies 2007; Sayer \& Wells 2004; Spiteri \& Nepal 2006) are at odds with the pressure to take action during the rare and short periods when there is a real political support for conservation projects (Menzies 2007; Wells et al. 2004; Young \& Rodríguez 2006). 
Moreover, central government agencies and officials might be reluctant to lose power and influence over such valuable resources due to political or personal interests (Adams \& Hulme 2001; Castro \& Nielsen 2001; Kumar 2002). Thus, the unusual opportunity of having the political will to establish a protected area, together with the location of the PNCAZ in the Tropical Andes hotspot (Myers et al. 2000) might explain the urgency with which the Park was created. On the other hand, it is another example of a conservation project initiated from outside the local communities.

The management period of 2002-2008 had a more participatory approach than the establishment phase. During this second management stage, communities participated in the development of the PNCAZ's Management Plan and the Acuerdos Azules represented a clear effort to involve local people in conservation activities (linked to a capacity building scheme). Also, the implementation in 2003 of a participatory management tool (the Mapeo de Usos y Fortalezas (Mapping of Social Assets and Resource Use -MUF)) with a clear commitment to share information with communities over a long time-frame (Gavin et al. 2007) might indicate a real commitment to involve local communities. In fact, the majority of the questionnaire respondents perceived that their communities participated in the Park's decisions (see Figure 3.2), although the majority of these informants were unclear about how communities were incorporated into these decisions. Consequently, it is possible that this pattern is due to respondents' acquiescence, that is, respondents answering what they thought I wanted to hear (Bernard 2002).

In relation to the current management stage, it appears that participatory levels were a bit lower than in the previous management stage. For example, the 2008 MUF edition (see section 3.2.3.2) was less participatory than the 2003 version which might indicate that participation was affected by issues of expediency with the conservationists' agenda. Also, the Management Committee was not yet properly functioning. However, this third management phase has recently started; hence it might be too early to compare with the previous stages. Nonetheless, results from the questionnaire showed that people thought they were participating in the current Park's management (see Figure 3.4), by mainly helping or supporting the Park guards in the conservation of the Park. This concurs with some of the interviewees' opinions, who felt that communities were only participating in fieldwork but not in the decision-making process. Thus, based on the results, it seems that communities were contributing with manual labour, such as patrolling (reducing a costly State -INRENAresponsibility), but with the Management Committee not working properly communities did 
not appear to have the same level of responsibility when it came to the governance of the PNCAZ. Unfortunately, this seems to be a common flaw in many conservation projects, which tend to pass to communities the burden of the protection and caring of protected areas. However, these same communities often do not enjoy the same level of decision-making authority (Adams \& Hulme 2001; Berkes 2007; Haller et al. 2008; Menzies 2007; Mutandwa \& Gadzirayi 2007; Spiteri \& Nepal 2006). Reasons for this scarce devolution of power and responsibility to communities are diverse and will vary from one project to another. Literature in conservation management however, points out that conservationists are usually unwilling to go beyond their agendas to implement longer and probably costlier participatory processes (Menzies 2007; Sayer \& Wells 2004). This is so, because participatory management involves local capacity building schemes and the negotiation of trade-offs between different interests that might compromise the achievement of conservation goals (Adams \& Hulme 2001; Castro \& Nielsen 2001; Chapin 2004; Kumar 2002; Menzies 2007; Wells et al. 2004). Some signals that this might have occurred in the PNCAZ are the fact that the Acuerdos Azules did not work, and the change in the manner in which the MUF was implemented. Therefore, the key barrier to greater participation during the PNCAZ's establishment appeared to be the urgency with which conservationist needed to proceed. During the second PNCAZ's management stage the main barriers to increased participation were the lack of consistency when applying the Acuerdos Azules and the narrow communities' power in the Park's governance. Finally, during the current management stage the main barrier to greater participation appeared to be an issue of expediency with the conservationists' agenda.

The fact that these three management stages depict different levels of participation demonstrates the importance of analysing participation at different management stages. Community participation in early stages of management is more challenging as it can require that conservationists might have to transcend their interests and agenda and commit to a longterm process that takes into account local interests, which can be in conflict with the conservationists' interests and the need for rapid action (Adams \& Hulme 2001; Menzies 2007; Romero \& Andrade 2002). 


\subsection{Participation link to Perceived Protected Area's Cost-Benefits}

The third objective of my thesis was to examine the relationship between locally perceived levels of participation and locally perceived costs and benefits stemming from the Park. The literature suggests that incentives are critical in getting local communities to participate in conservation management (Castro \& Nielsen 2001; Haller et al. 2008; Hedge \& Enters 2000; Kiss 2004; Menzies 2007; Spiteri \& Nepal 2006; Thakadu 2005), and therefore we can expect greater locally perceived net benefits from conservation to lead to more local interest in participating in management. At the same time, community participation seems to foster communities' vested interest in conservation (Adams \& Hulme 2001; Menzies 2007; Spiteri \& Nepal 2006), and in turn higher levels of participation may increase the chances of local people perceiving more benefits than costs from conservation management.

Questionnaire results indicated that local people near PNCAZ were conscious of the benefits that stemmed from the National Park. In fact, only a few respondents perceived that the PNCAZ was causing losses to them (see Figure 3.15). Respondents viewed the Park as a source of animals for hunting and fishing and many mentioned ecosystem services as the benefits arising from the protected area. These findings might reinforce the idea that community participation can be linked to communities' vested interest in conservation, as local people appeared to acknowledge the benefits of the protected area for natural resources. Furthermore, interviewees felt that communities were valuing the National Park and that local people accepted the project. For instance, Andres Cenepo (Park guard and local community member) pointed out that the majority of the local people knew about the Park's benefits, and Dave Pogois (PNCAZ Programme Director) and Alaka Wali (Field Museums' Director of the CCUC) highlighted how communities' acceptance of the PNCAZ has translated into low levels of conflict and encroachment (see section 3.4.2). Thus, it appears that community participation also led to local people either supporting or at least not opposing the PNCAZ.

Also, the perceived benefits from the Park were positively correlated with the perceived participation (see Table 3.4). The fact that these correlations were weak might be explained by the large number of confounding variables that influence perceived participation. Nonetheless, of the factors analysed with a logistic regression test, the perceived benefits from the Park and more notably the perceived costs affected the perceived responsibility for the Park's management (see Table 3.6). In the logistic regression model an increase in the locally perceived costs was linked to a decrease in the perceived responsibility for the 
management of the PNCAZ. Also, results from the regression analysis show that an increase in the locally perceived benefits stemming from the Park increased the perceived responsibility for the Park's management.

Consequently, these findings emphasize the idea that if managers would like to encourage local participation in conservation, there should be a focus on perceptions of the relative costs and benefits of the protected area. Hence, incentives are a critical component of participatory processes (Castro \& Nielsen 2001; Haller et al. 2008; Hedge \& Enters 2000; Kiss 2004; Menzies 2007; Spiteri \& Nepal 2006; Thakadu 2005).

\subsection{Barriers to more Participation}

Given that literature suggests that many conservation projects do not promote total community participation (Adams \& Hulme 2001; Kellert et al. 2000; McShane \& Wells 2004; Mutandwa \& Gadzirayi 2007) the second objective of this study was to examine the possible barriers to more participation in the PNCAZ. Some potential barriers to increased participation in conservation management previously mentioned in this chapter were: the conservationists' tight agendas (due to both the need of rapid action and the rare political windows of support to conservation); and the perceived benefits and costs. Other potential barriers identified in the literature that were empirically tested in this case study are first briefly presented (below) and then will be each discussed in the next four subsections. This section will end with a discussion of the main results from the logistic regression analysis.

The way in which participation is defined by stakeholders can influence the ultimate levels of community participation achieved (Kumar 2002; Mayo \& Craig 2004). Also, community members' attitudes towards conservation -in terms of acceptance of the project and willingness to participate in it- can be affected by their relationship with conservationists (Menzies 2007; Spiteri \& Nepal 2006; Thakadu 2005). Lastly, locally perceived ownership of the conservation project (Haller et al. 2008; Menzies 2007), and different socio-demographic variables, such as residence time and education levels, influence community resource uses and might indirectly affect participation (Gavin \& Anderson 2007; Spiteri \& Nepal 2006; Thakadu 2005). 


\subsubsection{Views of Participation and Attitudes towards Community Participation}

Definitions of participation vary depending on the context and background in which participation is applied (Kumar 2002). Thus, perceptions of the participation definition can themselves be a barrier to increased participation. In the case of the PNCAZ different ways of understanding participation in conservation management between conservationists and community people translated into different perceptions of the levels of participation in the Park's management. Thus, most of the conservationists viewed participation as taking part in different aspects of the Park's management (working or supporting the Park guards; actively taking part in the decision-making process), and some of the interviewees also pointed out that participation might have been limited by expediency with the conservationists agenda (see section 3.2.1). On the other hand, local people seemed to understand participation in the PNCAZ's management as simply contributing to labour (supporting Park guards and assisting to identify illegal resource users). Therefore, community people saw participation in conservation as limited to labour and thus local people did not seem to expect more communities' participation. This might change if they had a different view of participation in conservation management. Alternatively, conservationists had a broader view of participation and thus, were more critical than community members in regards to the levels of participation achieved.

Currently it appears that the prior contribution of local communities to the management of the Park was mainly to support the Park guards. Nonetheless, this joint effort seemed to be working well, as many of the interviewees highlighted the low levels of encroachment on the PNCAZ (see section 3.4.2). Also, local acceptance of the Park might indicate that local people were supportive of conservation, which in turn might foster more community participation in the PNCAZ's management. Attitudes (among other components) are an important factor determining peoples' behaviours (Jacobson et al. 2006; Kollmuss \& Agyeman 2002). Hence, in the logistic regression model positive attitudes towards the PNCAZ were linked to an increase in people's perceived responsibility for the conservation management of the Park (see Table 3.6). Lastly, most of the questionnaire respondents did not perceive the Park as causing them losses (see Figure 3.15) and considered to have more positive than negative impacts from the Park (see Figure 3.16). Also, results show that an overwhelming majority was eager to increase community participation (see Figure 3.6). Based on these results it appears that communities did not perceive the PNCAZ's participation model as a burden. 
Therefore, local people seemed to be amenable to provide labour although they did not share the same levels of decision-making power. These results appear to be in contrast with claims in the literature of unfair participatory process where communities bear only the burden of the protected area's labour (Adams \& Hulme 2001; Berkes 2007; Chapin 2004; Haller et al. 2008; Menzies 2007; Spiteri \& Nepal 2006). A few different reasons might explain this disagreement. As Thakadu (2005) points out, the issue of community readiness (in terms of having the personnel, funding and capacities to implement the project) would be as important for the sustainability of a project as having communities willing to participate. Thus, there is the possibility that local people simply did not want to bear the additional burden -time and responsibilities- that would be required for taking part in management decisions. In fact, attitudes towards conservation did not appear to be a fundamental barrier to participation in the PNCAZ case study. Furthermore, the majority of respondents seemed to be eager to increase their communities' participation in the PNCAZ's management, and there was also a significant positive (albeit weak) correlation between the attitudes towards participation and the perceived responsibility for the Park's management (see Table 3.5). On the other hand, it might be the case that community people were never told that they could have greater participation in the management of the Park and so they believed that the current situation was how things were supposed to be.

\subsubsection{Communities-Conservationists Relationship}

The literature indicates that the relationship between conservation agencies and local people is an important factor determining levels of community involvement (Adams \& Hulme 2001; Menzies 2007; Spiteri \& Nepal 2006; Thakadu 2005). For instance, if conservationists see communities as the main threat to the protected area, conflicts are likely to arise. On the other hand, if local people do not trust conservationists or see them as threatening their livelihoods, then, communities may be reluctant to participate in management efforts.

The results of this study suggest that there was a good relationship between local people and conservationists (see Figure 3.7). The relationship appeared to be particularly strong between community people and the Park guards (see Figure 3.9). A possible explanation for this good relationship between communities and the Park guards might be the fact that, in many cases, the Park guards were from a community of the PNCAZ's buffer zone.

Consequently, the positive relationship between conservationists (and more specifically the Park guards) and communities, the fact that respondents seemed to be eager to participate 
more, and the low levels of encroachment in the PNCAZ seem to highlight the importance of considering community people as critical allies for conservation (Agrawal \& Gibson 2001; Berkes 2007; Brechin et al. 2002, Menzies 2007; Spiteri \& Nepal 2006; Thakadu 2005).

\subsubsection{Communities’ Perceived Control over the PNCAZ}

Literature suggests that the extent to which community members perceive themselves as having some stake in the ownership of the project, or the protected area, seems to influence the level of local interest in participating in conservation management (Adams \& Hulme 2001; Kumar 2002; Menzies 2007). Results from the Cordillera Azul show that although 24 people stated correctly that the Park belonged to Peru, a similar amount of informants -23 people- were unsure who owned the protected area, and also 15 people stated it was foreign owned (see Figure 3.10). Thus, it could be argued that many local people may not identify with the PNCAZ given their lack of knowledge over its ownerhsip.

In addition, it seems that communities were willing to participate even though local people did not all feel they had a stake in the Park's ownership. Furthermore, this study has also illustrated that the locally perceived benefits were greater than the perceived costs hence, local people were still eager to participate in the PNCAZ management. Therefore, the perceived benefits and costs may be a more important barrier (or trigger) to community participation in conservation than the perceived ownership.

\subsubsection{Effect of Socio-Demographic variables on Participation}

Neither of the socio-demographic variables I analyzed (time of residence and levels of education) showed a significant effect on attitudes towards participation or local perceptions regarding participation. In addition, household's residence time was only weakly correlated with the locally perceived benefits from the bush inside the Park, so residence time did not explain a very large percentage of the variance in the locally perceived benefits from the bush inside the PNCAZ.

Besides the fact that a myriad of variables influence both perceptions about participation and the perceived benefits and costs, another possible explanation for the very weak correlation between socio-demographic variables and respondents' answers might be the small size of the sample (73 questionnaire respondents). Nonetheless, it appears that the respondents that have lived in an area the longest were less likely to perceive net benefits stemming from the bush inside the Park. Consequently, results from this study might 
highlight the fact that people who were used to having free access to natural resources in the past are now less likely to perceive the Park, and its restrictions on resource use, to be very beneficial.

None of the three categories of potential barriers to perceived participation in the PNCAZ (Attitudes towards conservation; communities-conservationists relationship; and perceived benefits and costs - see Figure 3.17) included in the regression analysis appeared to significantly influence the perceived local involvement in the Park's management. This lack of correlation in the logistic regression might be due to the fact that there was not a lot of variance in the answers obtained about the perceived local involvement in the Park's management. Therefore, there was not much variance that could be explained for any given variable, resulting in a lack of correlation between the potential barriers to perceived participation and the perceived local involvement. However, the perceived benefits and costs -and more specifically, the locally perceived costs- was able to explain some of the variance in perceived responsibility for the PNCAZ's management. Attitudes towards conservation also appeared to affect the perceived responsibility for the management of the Park. Therefore, it appears that if local people perceive that benefits outweigh the costs of communities' participation in conservation, and provided that these people hold proconservation attitudes, then community people are likely to perceive some responsibility for the Park's management. These findings demonstrate the complexity of the relationship between perceived participation and its potential barriers and triggers. In spite of that, a key implication of these findings is a stress on the importance of outweighing the conservation costs with economic benefits and/or other incentives in order to encourage community participation in the protected area's management (Castro \& Nielsen 2001; Haller et al. 2008; Hedge \& Enters 2000; Kiss 2004; Menzies 2007; Spiteri \& Nepal 2006; Thakadu 2005). Moreover, it would be critical to increase participatory levels in conservation considering that local people can be essential allies and key stakeholders in the Park's management.

Barriers to participation may also vary between different locations, and thus results of this case study cannot be widely generalised. Yet, in this study conservationists' reluctance to transcend their agendas seemed to constrain the levels of participation, particularly in the early stages of management. In addition, of the other possible barriers that were empirically tested in this thesis, the perceived benefits and costs appeared to be the main variable affecting locally perceived participation. 


\subsection{Management Implications}

The fourth and last objective of this thesis was to explore the implications of the perceived levels of participation for the conservation management in the Cordillera Azul National Park. To do so, I divided this section into two parts. In the first part I will discuss, based on the findings of this case study, the main management implications for the conservation management discipline in general. This will be followed by the key implications for the future PNCAZ management.

\subsubsection{General Implications}

This case study shows that levels of participation vary across different management stages. Also, literature shows that conservation is not a one-off event (Adams \& Hulme 2001; Slocum et al. 1995), and neither is participation in conservation (Kumar 2002; da Silva 2004). Thus, it appears that in order to increase participation in conservation management, levels of participation need to be considered at each phase of the management process. Furthermore, if participation is critical and varies at different stages, it reinforces the need for an adaptive management approach that measures levels of participation and barriers over time and adjusts management tools and actions to fit changing conditions.

In addition, it seems essential that policy-makers and conservationists encourage long-term participatory process where local participation is not just a required step to justify a protected area (Chapin 2004; Kumar 2002; Mayo \& Craig 2004; Menzies 2007). As this case study illustrates achieving high levels of participation at early stages of protected areas' management might be constrained by the urgency with which conservationists need to proceed. This rush is often caused by the lack of political support for conservation (Menzies 2007; Wells et al. 2004; Young \& Rodriguez 2006). Therefore, to increase participatory levels in all the management stages it would be critical to give enough time to guarantee that communities have the skills and resources to make informed choices. A long-term management framework is required to establish participatory processes where local people choose conservation because there are clear incentives to do so, and thus participation it is not just a system to seek communities' consent for conservation projects (Chapin 2004; Kellert et al. 2000; Kumar 2002; Menzies 2007; Sayer \& Wells 2004). To do so, it would require a fundamental shift in how conservation (and the governance of protected areas in general) occurs in Peru. 


\subsubsection{Implications for the PNCAZ}

The literature suggests that favouring local participation in the management of protected areas would be likely to increase compliance and reduce conflicts in those areas (Agrawal \& Gibson 2001; Berkes 2007; Brechin et al. 2002). Furthermore, there are moral reasons, as participatory processes are supposed to take into account the views and opinions of those more directly affected by protected areas (Adams \& Hulme 2001; Brechin et al. 2002; Horwich \& Lyon 2007; Menzies 2007; Spiteri \& Nepal 2006).

Results from this case study illustrate that local people want to participate more in the management of the PNCAZ. Thus, it would be reasonable for the Park's managers to encourage more community participation given the potential benefits that this approach has for conservation. However, many conservation projects have often, to varying degrees, passed on to communities the responsibilities of the protection and caring of protected areas while these communities do not enjoy the same level of decision-making power (Adams \& Hulme 2001; Berkes 2007; Haller et al. 2008; Kumar 2002; Menzies 2007; Spiteri \& Nepal 2006). Based on the results, the current situation in the PNCAZ's management seems to be that local communities are mainly supporting the Park guards, and having very little influence in the Park's decisions. Consequently, it might be argued that the people-oriented management model of the PNCAZ is not really implementing its social justice or moral component. Some possible explanations for the limited ways in which people appear to want to participate are due to: a limited capacity (in terms of community readiness), or because communities are unwilling to take on additional burdens. However, more investigation is needed to clearly understand why there is no more community participation in the Park's decisions.

If communities are indeed willing and able to take on additional decision-making responsibilities several options do exist for management to incorporate local communities into the decision-making framework of the PNCAZ's management. Management tools like the Acuerdos Azules and the Management Committee might foster more community involvement in the PNCAZ's management. However, the role of the Acuerdos Azules and the Management Committee should be revised and managers need to consider how these management tools might be improved to foster more community involvement in the decisionmaking process. 
As Menzies (2007) points out, if community participation in conservation is not enhanced then the conflicts and costs to both society and the environment are going to certainly be higher than the efforts and costs to improve local participation. Thus, increasing the scope for community participation in conservation might benefit both communities and the PNCAZ itself, yet the implementation of such approach to conservation management is a major challenge (Adams \& Hulme 2001; Berkes 2007; Kellert et al. 2000; Spiteri \& Nepal 2006; Wells et al. 2004). However, based on the results from the logistic regression analysis, it seems that to increase communities' participation in conservation, managers should focus on identifying those community members with pro-environmental attitudes, as well as paying special attention to the costs and benefits of conservation.

\subsection{Suggestions for Future Research}

This research was limited by time and funding, and therefore considerable room remains for related studies. Also, this case study was limited to one sector of the PNCAZ, thus the situation may vary in other regions where different ethnic groups dominate or where different ecological conditions prevail. Thus, it would be advisable to do other studies in different contexts (e.g. communities from the Ucayali, or from the Polvora sector, or studies involving the Shipibo-Conibo ethnic group). Also, socio-demographic variables analyzed with the questionnaire (time of residence and levels of education) did not show a clear effect on local people's attitudes towards participation in the management of the Park, although it seems that households' residence time has a significant influence in the locally perceived net benefits.

Although this study was limited due to a small sample size, these results provide the first step towards creating multi-variate models containing key determinants of participation which might improve the conservation management of protected areas. Yet, more research is needed to clearly identify all the key barriers to greater participation that will be then included in these types of models. Thus, determining why there are differences in how stakeholders define participation might be a critical step towards identifying the major barriers to increased participation in conservation.

Lastly, the literature demonstrates that there is a clear correlation between community participation and the perceived benefits (Adams \& Hulme 2001; Castro \& Nielsen 2001; Haller et al. 2008; Kiss 2004; Menzies 2007; Spiteri \& Nepal 2006; Thakadu 2005) yet the 
direction of causality between levels of participation and the perceived benefits and costs has never been tested. This study could not determine either the direction of causality between locally perceived participation and the locally perceived benefits and costs. Therefore, establishing the direction of causality for these relationships might prove to be crucial to increase community participation in conservation, and therefore to improve the management of protected areas.

\subsection{Conclusions}

Conservation of natural resources is an evolving process, hence community participation in conservation might vary both in terms of the mechanisms under which participation of local people is achieved, and in the levels of participation reached. This research has found that community participation levels vary across different stages of protected area management. Although during PNCAZ's establishment communities were hardly taken into account, their role in the Park's management increased in the following years. These findings indicate that having participatory processes in the conservation management is challenging because it involves taking into account communities' interests that are likely to differ from the conservationists' goals. In addition, not only has participation changed over time, but the degree of participation of local communities in PNCAZ's management has been limited to manual labour tasks, such as patrolling of the PNCAZ. Besides, community participation in the governance of the Park has been and still remains low.

Some of the potential barriers to increase participation in conservation management were examined in this case study. Results show that participatory levels were limited to some extent by issues of expediency with the conservationists' agenda. Also, perceptions of the participation definition can themselves be a barrier to increased participation in conservation. Stakeholders might differ in their views of what participation means in terms of rights and duties which in turn might restrict the levels of participation achieved. Nonetheless, attitudes towards conservation did not appear to be a fundamental barrier to participation, nor was the good relationship between local people and conservationists (being particularly strong between community people and the Park guards). Lastly, the perceived ownership of the PNCAZ did not appear to be a fundamental barrier to participation. Thus, although local people did not all feel they had a stake in the Park's ownership the majority of them were nevertheless willing to increase communities' participation in the PNCAZ's management. 
This case study in the Cordillera Azul National Park has also shed some light on the link between locally perceived participation and the locally perceived benefits and costs. Results from the logistic regression indicate that there was a correlation between the perceived benefits and costs from the PNCAZ and the perceived responsibility for the Park's management. Also, the majority of respondents did not perceive the Park as causing them losses. Thus, it seems critical that in order to increase community participation in conservation, benefits need to outweigh the conservation costs placed on communities.

Therefore, based on the findings of this thesis, participatory approaches to conservation management need to be set under adaptive, long-term management frameworks. Also, if managers want to increase community participation in the protected area's management, they might need to focus on identifying those community members with particular attitudes and concentrate on the benefits and costs of conservation.

Finally, my research has found that local people value the PNCAZ and it seems that there is also the will from the community side to participate in the management of the PNCAZ. Moreover, even though the levels of participation have not been very high, local people's perceptions were that they have been participating. Thus, managers' efforts made until now to involve communities should not be dismissed. However, it is incumbent on all of those benefiting from the PNCAZ's establishment that local communities are not bearing all the cost that the Park impose on them. Hence, the scope for community participation in the governance of the PNCAZ should be increased provided that community members are willing and able to take on additional responsibilities. In doing so, this conservation project will promote a real participatory management, overcoming the unbalanced stewardship common to most of the protected areas. 
Appendix 1: CIMA's working sector division of the Park.

\begin{tabular}{|c|c|}
\hline 1 & HUIMBAYOC. \\
\hline 2 & CHAZUTA. \\
\hline 3 & ALTO BIAVO. \\
\hline 4 & BAJO BIAVO. \\
\hline 5 & SHAMBOYACU. \\
\hline 6 & TRES UNIDOS. \\
\hline 7 & ALTO PAUYA. \\
\hline 8 & POLVORA. \\
\hline 9 & SHAPAJA. \\
\hline 10 & PUCAYACU. \\
\hline 11 & AGUAYTIA. \\
\hline 12 & CUSHABATAY. \\
\hline 13 & PISQUI. \\
\hline 14 & PIQUIYACU. \\
\hline 15 & ORELLANA. \\
\hline
\end{tabular}

Adapted from INRENA (2006). 


\title{
Appendix 2: Written permission of the Head of the Park.
}

\author{
INSTITUTO NACIONAL DE RECURSOS NATURALES \\ PARQUE NACIONAL CORDILLERA AZUL
}

\section{CARTA DE PRESENTACIÓN}

Por medio de la presente, se hace de su conocimiento a las Autoridades que correspondan, que el Sr. Emilio Arturo Rodríguez Izquierdo, con pasaporte Español No con motivo de la investigación para el desarrollo de su tesis de maestría relacionada con el Manejo del Parque Nacional Cordillera Azul, llevará a cabo su investigación en las comunidades aledañas al mencionado parque, contando con el beneplácito de la Jefatura del Parque, con sede en la ciudad de Tarapoto, en Jr. Leguía Nº 244-Morales.

Agradecemos le brinden las facilidades a la persona portadora de la presente carta, en beneficio de facilitar el desempeño de sus actividades en campo sin mayor inconveniente.

Tarapoto, 10 de Julio del 2008

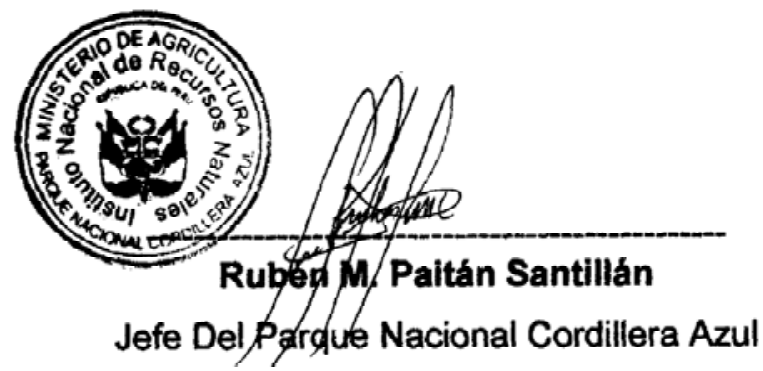

Translation:

This document is to acknowledge to the pertinent Authorities that Mr Emilio Arturo Rodríguez-Izquierdo, with a Spanish passport $\mathrm{N}^{\circ}$, will be conducting research in the communities surrounding the Cordillera Azul National Park with the permission of the Head of the Park, given that his thesis research is related to the Management of the Cordillera Azul National Park. The office of the Head of the Park is located at the city of Tarapoto, in Jr. Leguía N²44-Morales.

We will appreciate any help given to the holder of this letter in order to facilitate his fieldwork. 


\title{
Appendix 3: Information Sheet and Informed Consent Form for Semi- structured Interview Respondents.
}

\author{
Participant Information Sheet (Officials and Experts) \\ Master's Thesis Research Project: \\ "Barriers and triggers to adopting a participatory model for conservation in the Cordillera Azul \\ National Park, Peru"
}

[Month, 2008]

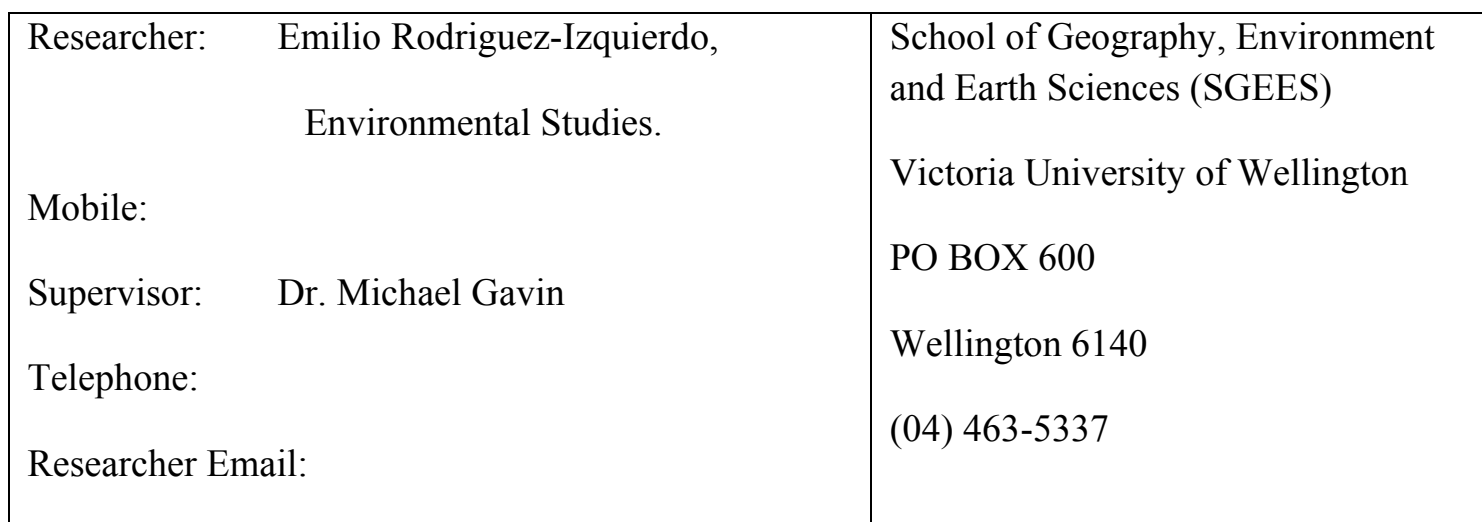

Dear Project Participant,

You are being asked to take part in an interview for my Master's thesis at Victoria University of Wellington. The project will investigate the participatory model for conservation adopted in the Cordillera Azul National Park. The study will answer the following major questions:

What differences are between principal stakeholders perceptions' about the new participatory approach to conservation management in the Cordillera Azul National Park?

What are the perceived costs and benefits of this new conservation model?

Which are the main barriers and triggers for the adoption of the participatory conservation model?

I am inviting you to participate in this study. I would like you to answer some questions as part of a semistructured interview about the participatory approach taken in the Cordillera Azul National Park. I will take interview notes, and I will use a tape-recorder during the interview. You can turn off the taperecorder at any time during the interview. The tape will be transcribed with your permission. The interview will not exceed more than one hour.

\section{Confidentiality}

At the beginning of the interview I will explain in detail how the results of the research may be used, including the potential for publication in the public domain, in the form of academic papers in peer reviewed journals or presentations at conferences, and the possibility of releasing data from the surveys to CIMA and INRENA, but it will be only presented in aggregated form.

The Informed Consent Form (attached) will ask you whether you require confidentiality or not, and how you wish to identify yourself in the research. If you do not require confidentiality, you will be asked to circle the relevant statement, and only then will your identity be published. 
If you do require confidentiality, then no names will appear on the transcripts and a letter-number code will be assigned to each interview respondent, and only this code, or other title specified by you, will appear in the published results (unless confidentiality is waived as described above).

In the case of confidential informants, the real names associated with the codes will be kept securely by me, and never made public without the permission of the individual(s) involved.

\section{Storage and Disposal of Data}

Access to the written and electronic material will be restricted to me and my supervisor (Dr. Michael Gavin). These data will not be destroyed to allow for long-term analysis. All written material will be kept in a locked file, and all electronic material will be password protected.

The results collected will be reported in my thesis, and will be potentially presented in academic journals and conferences. The thesis will be submitted to the School of Geography, Environment and Earth Sciences, Victoria University of Wellington.

\section{Right of Withdrawal}

During the course of the interviews, you will have the right to withdraw from the interview or refuse to answer any question(s) at any time. You may request that the transcript of your interview be destroyed and not used in the study, for any reason. You must inform me of your withdrawal no more than 8 weeks after the date of the interview.

\section{Provision of Feedback}

You have the right to check the interview transcript, and will be able to provide any corrections at any time, prior to final analysis of data.

\section{Community Access to Research Results}

In order to ensure that the results of this research project are accessible to the participants, a summary of the completed research output will be available. Copies of the completed research output will be provided to CIMA, INRENA, the Field Museum and community leaders.

If you have any other questions about this project, please feel free to ask me now, or contact me, or my supervisor Dr. Michael Gavin later, from the contact details provided on the first page of this sheet.

Thank you for participating!

Sincerely,

\section{Emilio Rodríguez-Izquierdo.}


Master's Thesis Research Project:

"Barriers and triggers to adopting a participatory model for conservation in the Cordillera Azul National Park, Peru”

INFORMED CONSENT FORM

\begin{tabular}{|l|l|}
\hline Researcher: Emilio Rodriguez-Izquierdo & School of Geography, \\
Mobile: & Environment and Earth Sciences \\
Email: & (SGEES) \\
Supervisor: Dr. Michael Gavin & Victoria University of \\
Tel.: & Wellington \\
& PO BOX 600 \\
& Wellington 6140 \\
& $(04) 463-5337$ \\
\hline
\end{tabular}

\section{Introduction}

The Victoria University of Wellington Human Ethics Committee, which has approved this research project, requires that all research involve Participants who are: 1) fully informed about the nature of the research; and 2) consent to participate. This "Informed Consent Form" has been designed in accordance with these requirements, to inform all Participants about the nature of the project and their participation in it. It is meant to ensure that research Participants and their communities are protected from any harm potentially arising from their participation in the research process.

\section{Purpose of the Study}

This study, for my Master's thesis, is intended to answer the following question:

What differences are between principal stakeholders perceptions' about the new participatory approach to conservation management in the Cordillera Azul National Park?

What are the perceived costs and benefits of this new conservation model?

Which are the main barriers and triggers for the adoption of the participatory conservation model?

Please also see the attached 'Information Sheet'

\section{Research Format}

Data will be collected with both semi-structured interviews and a survey. You are being asked to participate in a semistructured interview. Qualitative field research will be undertaken by interviewing a variety of Participants in different locations.

Participants will be asked to take part in a semi-structured interview, at a time and a place that suits them. Participants are being asked to consent to obtain data from them relating to their perceptions about the participatory approach taken in the Cordillera Azul National Park. Questions are not of a personal nature. Each interview will not exceed one hour. 
1. I agree to an audio recorded interview

Please circle one

with Emilio Rodriguez-Izquierdo.

2. I wish for my identity to remain confidential.

If yes, please answer 3. If no, please skip to 4.

3. I would like to be identified as (please circle one):

a) An 'official' from the organisation I represent, or

b) A letter code, or

c) Other, please specify:

4. I consent to information or opinions that I have given being attributed to me in any reports on this research.

$$
\mathrm{Y} / \mathrm{N}
$$

5. I understand that upon request I will have an opportunity to correct the transcript of the interview before publication.

If yes, My address is:

My email is:

6. I understand that the data I provide will not be used for any other purpose than described in the 'Information Sheet' or released to others without written consent.

$\mathrm{Y} / \mathrm{N}$

7. I understand that a summary of the results will be provided to CIMA, INRENA, the Field Museum and to the communty leaders.

$$
\mathrm{Y} / \mathrm{N}
$$

I agree to take part in this research

Participant:

Name:

Date:

Signature:

Researcher:

I certify that this form and its attached "Information Sheet" cover letter provide a complete and accurate description of the aims and processes of this research project.

Name:

Date:

Signature: 


\section{Appendix 4: Questionnaire}

1. Community:

2. Sex:

3. Date:

\section{Knowledge of the Park and its management.}

To start with, I will ask you some questions about the National Park and its management. Please answer the following questions with yes, no or don't know, to the best of your knowledge. I just want to know what you think. Do not worry if you do not know an answer to a question. If you do not know, just tell me. You only need to answer honestly. If you do not understand a question, please let me know.

4. Is there a National Park nearby?

- Yes

- No $\rightarrow$ Do you know the Cordillera Azul National Park?
a) Yes
b) No $\rightarrow$ go to question 26 .

5. Do you know the Acuerdos Azules?

- Yes

- $\quad$ No $\rightarrow$ go to question 7 .

6. Do the Acuerdos Azules take into account local necessities?

- Yes

- No

- Don't know.

7. Do you want your community to be more involved in the Park's management?

- Yes

- No

- Don’t know

8. Why did you answer like this? 
9. Do you think the Park has more positive than negative impacts on you and your family?

- Yes

- No

- Don't know.

- Neither positive nor negative.

\section{Participation in the management of the Park.}

Now, I am going to read you some statements about the establishment of the National Park. Please tell me whether you strongly agree, agree, neutral, disagree or strongly disagree. Sometimes, I will also ask you why you answered the way you did. There are no right or wrong answers. If you do not understand a question, please let me know.

10. How is your relationship with the Park's staff?

- Very good.

- Good.

- Neutral.

- Bad.

- Very bad.

- Don't know.

11. Why did you answer that way?

12. To whom does the Cordillera Azul National Park belong?

13. Your community is to some extent responsible of the Park's management:

- Strongly agree.

- Agree.

- Neutral.

- Disagree.

- Strongly disagree.

- Don’t know. 
14. How did your community take part in the creation of the Park?

\section{Support for the Cordillera Azul National Park}

I will now read you some statements about your perceptions of the Park. Again, please tell me whether you strongly agree, agree, neutral, disagree or strongly disagree with these statements. Remember, I just want to know what you think. Also, if you do not understand a question, please let me know.

15. Does CIMA staff listen to the problems of the people of this community?

- Strongly agree.

- Agree.

- Neutral.

- Disagree.

- Strongly disagree.

- Don't know.

16. Do the Park guards listen to the problems of the people of this community?

- Strongly agree.

- Agree.

- Neutral.

- Disagree.

- Strongly disagree.

- Don't know.

17. Local people are involved in the management of the PNCAZ:

- Strongly agree.

- Agree.

- Neutral.

- Disagree.

- Strongly disagree.

- Don't know. 
18. How do you think your community should take part in the management of the Park?

19. Does the Park provide any benefit to you and your family?

- Strongly agree.

- Agree.

- Neutral.

- Disagree.

- Strongly disagree.

- Don't know.

20. If so, what are those benefits?

21. Does the bush inside the Park provide any benefit to you and your family?

- Strongly agree.

- Agree.

- Neutral.

- Disagree.

- Strongly disagree.

- Don't know.

22. If so, what are those benefits?

23. Does the National Park cause losses to you and your family?

- Strongly agree.

- Agree.

- Neutral.

- Disagree.

- Strongly disagree.

- Don't know.

24. If so, what are these costs? 
25. Your community takes part in the Park's decisions:

- Strongly agree.

- Agree.

- Neutral.

- Disagree.

- Strongly disagree.

- Don't know.

26. Why did you answer like that?

\section{Household profile.}

To end up, I will now ask you a few questions about yourself and your household.

27. How old are you?

28. What is the highest level of education you have attained?

29. How long have you lived in this particular community?

30. Where were you born:

31. How many hectares of land do you own?

32. What animals and how many do you own?

\section{Comments}




\section{Appendix 5: Interview guideline.}

- How would you define 'participation'?

- Would you consider the Cordillera Azul National Park to be under a participatory management approach?

- Why was this management model chosen?

- Were you involved in the establishment of the Park? If so, what did you do?

- In your opinion, who should manage the PNCAZ?

- What attitudes do you think local communities have towards the Park and its management? In your opinion, are there any differences about it between western and eastern communities?

- How would you define the current relations among the main stakeholders in the Cordillera Azul National Park?

- Do you think local communities are better off or worse off since the establishment of the Park?

- What is your opinion of the Acuerdos Azules?

- In relation to the Management Contract, how would it affect the overall management? Would it bring more participation?

- To what extent were communities involved in the establishment of the Park?

- Peasant Rounds and volunteer Park guards $\rightarrow$ Do these tools increase participation?

- Management Committee, what do you think about it?

- What will be the future barriers for the participatory management of the Park? 
Appendix 6: Respondents views of the ownership of the Park.

\begin{tabular}{|c|c|c|}
\hline $\begin{array}{c}\text { 1/2 Peruvian } 1 / 2 \\
\text { Foreign }\end{array}$ & 3 & Prequency \\
\hline CIMA & 2 & $2.1 \%$ \\
\hline Don't know & 23 & $\mathbf{3 1 . 5 \%}$ \\
\hline Foreign & 4 & $\mathbf{5 . 5 \%}$ \\
\hline INRENA & 2 & $2.7 \%$ \\
\hline Peru & 20 & $\mathbf{2 7 . 4 \%}$ \\
\hline San Martin & 1 & $1.4 \%$ \\
\hline Selva Andina & 1 & $1.4 \%$ \\
\hline To communities & 2 & $2.7 \%$ \\
\hline To the State. & 4 & $\mathbf{5 . 5 \%}$ \\
\hline USA & 11 & $\mathbf{1 5 . 1 \%}$ \\
\hline Total & 73 & $100.0 \%$ \\
\hline
\end{tabular}




\section{Appendix 7: Socio-demographic data.}

Residence Time categories.

\begin{tabular}{|c|c|c|}
\hline & Frequency & Percent \\
\hline 0-1 years & 5 & 6.8 \\
\hline 2-5 years & 14 & 19.2 \\
\hline 6-10 years & 18 & 24.7 \\
\hline $\mathbf{1 1 - 1 5}$ years & 8 & 11.0 \\
\hline $\mathbf{1 6 - 2 0}$ years & 12 & 16.4 \\
\hline 21-30 years & 4 & 5.5 \\
\hline >31 years & 11 & 15.1 \\
\hline Total & 72 & 98.6 \\
\hline Not applicable & 1 & 1.4 \\
\hline Total & 73 & 100.0 \\
\hline
\end{tabular}

Levels of education categories.

\begin{tabular}{|c|c|c|}
\hline None & Frequency & Percent \\
\hline $\begin{array}{c}\text { Primary education } \\
\text { uncompleted }\end{array}$ & 32 & 2.7 \\
\hline $\begin{array}{c}\text { Primary education completed } \\
\text { Secondary education } \\
\text { uncompleted }\end{array}$ & 22 & 30.1 \\
\hline Total & 73 & 23.3 \\
\hline
\end{tabular}




\section{REFERENCES}

Adams, W.M., Hulme, D., 2001. If community conservation is the answer in Africa, what is the question? Oryx 35, 193-200.

Agrawal, A., Gibson, C.C., 2001. The Role of Community in Natural Resource Conservation, In Communities and the environment: ethnicity, gender, and the state in community-based conservation. eds. A. Agrawal, C.C. Gibson, pp. 1-31. Rutgers University Press, New Brunswick.

Agrawal, A., Redford, K., Fearn, E., 2008. Conservation and Human Displacement, In State of the Wild 2008-2009: A Global Portrait of Wildlife, Wildlands, and Oceans. eds. E. Fearn, pp. 198-205. Island Press, Washington.

Berkes, F., 2003. Rethinking Community-Based Conservation. Conservation Biology 18, 621-630.

Berkes, F., 2007. Community-based conservation in a globalized world. Proceedings of the National Academy of Sciences of the United States of America 104, 15188-15193.

Bernard, H.R., 2002. Research methods in Anthropology: Qualitative and Quantitative Approaches, Third Edition edn. AltaMira Press, Walnut Creek, CA.

Brechin, S.R., Wilshusen, P.R., Fortwangler, C.L., West, P.C., 2002. Beyond the square wheel: Toward a more comprehensive understanding of biodiversity conservation as social and political process. Society \& Natural Resources, 41-64.

Bromley, D.W., 1991. Property, Rights, and Property Rights, In Environment and economy: Property Rights and Public Policy. ed. D.W. Bromley, pp. 1-13. Blackwell, Cambridge.

Carpenter, J.F., 1998. Internally motivated Development Projects: A Potential Tool for Biodiversity Conservation Outside of Protected Areas. Ambio 27, 211-216.

Chapin, M., 2004. A Challenge to Conservationists. World Watch magazine, 17-31.

Cherryholmes, C.H., 1992. Notes on Pragmatism and Scientific Realism. Educational Researcher 14, $13-17$.

Castro, A.P., Nielsen, E., 2001. Indigenous people and co-management: implications for conflict management. Environmental Science \& Policy, 229-239.

Cerdán, M., 2002. Compendio de Legislación de Áreas Naturales Protegidas, Primera edn. INRENASPDA, Programa de Conservación, Lima.

Corbin, J., Strauss, A., 2008. Basics of Qualitative Research: techniques and procedures for developing grounded theory, Third edition edn. Sage Publications, California.

Creswell, J.W., 2003. Research design: Qualitative, quantitative, and mixed method approaches., 2nd edn. Sage Publications Inc., Thousand Oaks, California.

da Silva, P.P., 2004. From common property to co-management: lessons from Brazil's first maritime extractive reserve. Marine Policy 28, 419-428. 
Daly, H.E., Farley, J., 2004. Ecological economics: principles and applications. Island Press, Washington.

Dearden, P., Bennet, M., Johnston, J., 2005. Trends in Global Protected Area Governance, 1992-2002. Environmental Management 36, 89-100.

Field, A., 2005. Discovering statistics using SPSS: (and sex, drugs and rock 'n' roll), 2nd edn. SAGE Publications, London.

Fumerton, M., 2001. Rondas Campesinas in the Peruvian Civil War: Peasant Self-defence Organisations in Ayacucho. Bulletin of Latin American Research 20, 470-497.

Gavin, M., Wali, A., Vasquez, M., 2007. Working towards and beyond collaborative resource management: Parks,people, and participation in the Peruvian Amazon, In Connecting People, Participation and Place: Participatory Action Research Approaches and Methods. eds S. Kindon, R. Pain, M. Kesby. Routledge, London.

Gavin, M.C., Anderson, G.J., 2007. Socioeconomic predictors of forest use values in the Peruvian Amazon: A potential tool for biodiversity conservation. Ecological Economics 60, 752-762.

Haller, T., Galvin, M., Meroka, P., Alca, J., Alvarez, A., 2008. Who Gains From Community Conservation? Intended and Unintended Costs and Benefits of Participative Approaches in Peru and Tanzania. The Journal of Environment \& Development 17, 118-144.

Hambler, C., 2003. Conservation. Cambridge University Press, New York.

Hardin, G., 1968. The tragedy of the commons. Science 162, 1243-1248.

Hedge, R., Enters, T., 2000. Forest products and household economy: a case study from Mudumalai Wildlife Sanctuary, Southern India. Foundation for Environmental Conservation 3, 250-259.

Horwich, R.H., Lyon, J., 2007. Community conservation: practitioners' answer to critics. Oryx 41, 376-385.

INEI (Instituto Nacional de Estadística e Informática). (2007). XI Censo de Población y VI de Vivienda 2007. Retrieved 17 February, 2009, from: http://desa.inei.gob.pe/censos2007/tabulados/

INRENA (Instituto Nacional de Recursos Naturales) 2006. Parque Nacional Cordillera Azul, Plan Maestro (2003-2008). INRENA, Lima, Perú.

Jacobson, S.K., Mc Duff, M.D., Monroe, M.C., 2006. Changing conservation behaviors, In Conservation Education and Outreach Techniques. pp. 63-84. Oxford University Press, Oxford.

Kellert, S.R., Mehta, J.N., Ebbin, S.A., Lichtenfeld, L.L., 2000. Community natural resource management: Promise, rhetoric, and reality. Society \& Natural Resources, 705-715.

Kiss, A., 2004. Making Biodiversity Conservation a Land-Use Priority., In Getting biodiversity projects to work: towards more effective conservation and development. eds T.O. McShane, M.P. Wells, pp. 98-121. Columbia University Press, New York. 
Kollmuss, A., Agyeman, J., 2002. Mind the Gap: Why do people act environmentally and what are the barriers to pro-environmental behavior? Environmental Education Research 3, 239260.

Kothari, A., 2006. Community Conserved Areas, In Managing Protected Areas: a global guide. eds M. Lockwood, G. Worboys, A. Kothari, pp. 549-572. VA: Earthscan, London, Sterling.

Kumar, S., 2002. Methods for community participation: a complete guide for practitioners. ITDG, London.

Margules, C.R., Pressey, R.L., 2000. Systematic conservation planning. Nature 405, 243-253.

Mayo, M., Craig, G., 2004. Community Participation and Empowerment: The Human Face of Structural Adjustment or Tools for Democratic Transformation?, In Community Empowerment: A reader in Participation and Development. eds G. Craig, M. Mayo. Atlantic Highlands, New Jersey. Zed Books, 1995, London.

McShane, T.O., Wells, M.P., 2004. Getting Biodiversity Projects to Work: Towards More Effective Conservation and Development. Columbia University Press, New York.

Meffe, G.K., Nielsen, L.A., Knight, R.L., Schenborn, D.A., 2002. Ecosystem Management: adaptive, community-based conservation. Island Press, Washington.

Menzies, N.K., 2007. Our forest, your ecosystem, their timber: communities, conservation, and the state in community-based forest management. Columbia University Presss, New York.

Mutandwa, E., Gadzirayi, C.T., 2007. Impact of community-based approaches to wildlife management: case study of the CAMPFIRE programme in Zimbabwe. International Journal of Sustainable Development and World Ecology 14, 336-344.

Myers, N., Mittermeier, R.A., Mittermeier, C.G., da Fonseca, G.A.B., Kent, J., 2000. Biodiversity hotspots for conservation priorities. Nature 403, 853-857.

Ostrom, E., 1990. Governing the Commons: The evolution of institutions for Collective Action. Cambridge University Press, Cambridge.

Robinson, J.G., Redford, K.H., 2004. Jack of All Trades, Master of None: Inherent Contradictions Among ICD Approaches, In Getting Biodiversity Projects to Work: Towards More Effective Conservation and Development. eds T.O. McShane, M.P. Wells, pp. 10-33. Columbia University Press, New York.

Romero, C., Andrade, G.I., 2004. International Conservation Organizations and the Fate of Local Tropical Forest Conservation Initiatives. Conservation Biology 18, 578-580.

Salafsky, N., Cauley, H., Balachander, G., Cordes, B., Parks, J., Margoluis, C., Bhatt, S., Encarnación;C;, Russell, D., Margoluis, R., 2001. A Systematic Test of an Enterprise Strategy for Community-Based Biodiversity Conservation. Conservation Biology 15, 1585-1595.

Salafsky, N., Margoluis, C., 2004. Using Adaptive Management to improve ICDPs, In Getting Biodiversity Projects to Work: towards more effective conservation and development. eds T.O. McShane, M.P. Wells, pp. 372-394. Columbia University Press, New York. 
Sayer, J., Wells, M.P., 2004. The Pathology of Projects, In Getting Biodiversity Projects to Work: Towards More Effective Conservation and Development. eds T.O. McShane, M.P. Wells, pp. 35-48. Columbia University Press, New York.

Slocum, R., Wichart, L., Rocheleau, D., Thomas-Slayter, B., 1995. Power, Process and Participation Tolls for Change. Intermediate Technology Publications, London.

Spiteri, A., Nepal, S.K., 2006. Incentive-based conservation programs in developing countries: A review of some key issues and suggestions for improvements. Environmental Management $37,1-14$.

Tai, H.-S., 2007. Development Through Conservation: An Institutional Analysis of Indigenous Community-Based Conservation in Taiwan. World Development 35, 186-1203.

Thakadu, O.T., 2005. Success factors in community based natural resources management in northern Botswana: Lessons from practice. Natural Resources Forum 29, 199-212.

The Field Museum of Chicago. (2007). Park Story. Retrieved 20 January, 2009, from: http://www.fieldmuseum.org/cordilleraazul/parkstory.html

Wells, M.P., McShane, T.O., Dublin, H.T., O'Connor, S., Redford, K.H., 2004. The Future of Integrated Conservation and Development Projects: Building on What Works, In Getting Biodiversity Projects to Work: Towards More Effective Conservation and Development. eds T.O. McShane, M.P. Wells, pp. 397-419. Columbia University Press, New York.

Wilshusen, P.R., Brechin, S.R., Fortwangler, C.L., West, P.C., 2002. Reinventing a Square Wheel: Critique of a Resurgent "Protection Paradigm" in International Biodiversity Conservation. Society \& Natural Resources 15, 17-40.

Worboys, G.L., Lockwood, M., De Lacy, T., McNamara, C., 2005. Protected Area Management: Principles and Practice, 2nd edn. Oxford University Press, New York.

Young, K.R., Rodríguez, L.O., 2006. Development of Peru's Protected-Area System: Historical Continuity of Conservation Goals, In Globalization \& New Geographies of Conservation. ed. K.S. Zimmerer, pp. 229-254. The University of Chicago Press, Chicago \& London. 